\title{
The Role of Social Media to Gain Social Security among Citizens in Sulaimani City
}

\author{
Assistant Lecture: Karwan Abdullah Muhammad \\ University ofSulaimani \\ College of Human Sciences \\ Media department \\ Assistant Lecture: HarmnSherkoNasraden \\ Sulaimani Polytechnic University \\ Dukan Technical Institute \\ Department of Public Relations and Marketing
}

\begin{abstract}
This research entitled (The role of social media to gain social security among citizens in Sulaimani city). It works on the relations between media and feeling of individual security in society in a way That Media as a social mirror and stage of elaborating information, events, news and orientating society, how much take the role in calming society In social security in particular the security of finance, personal and society .

This work investigates on Sulaimani citizens and their contacts with media especially (social media) aiming to indicate the ratio of impacts of social media of gaining the social security in Sulaimani population. This study has been conducted using description methods and survey approaches and population above 18 years is taken as participants. For sampling procedures are depended on the random approach using (Morgan) table. Based on this method about 300 person was determined for this study.

Eventually we came to that conclusion that the majority of the social media users in Sulaimani city believed they are feeling unsecured in Sulaimani city. as well as most of them feel much threatened on their finance and personals but less on social security.
\end{abstract}




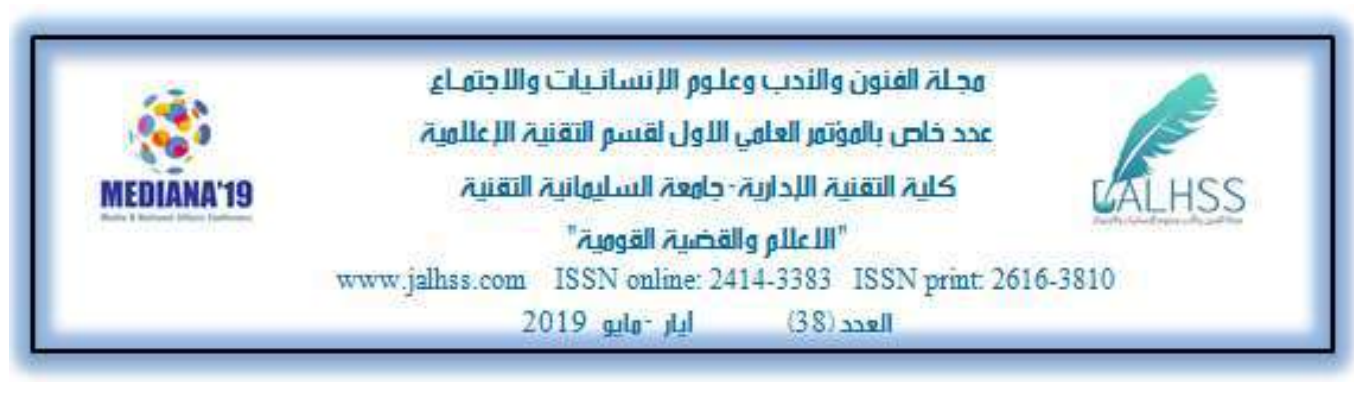

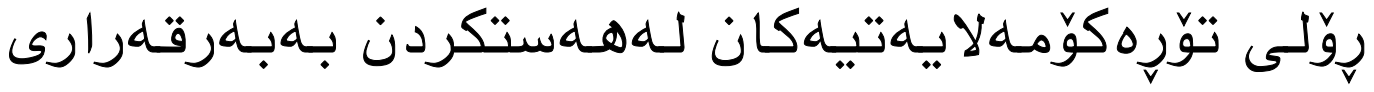

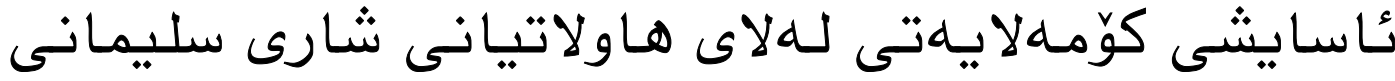

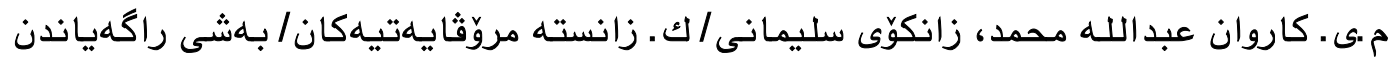

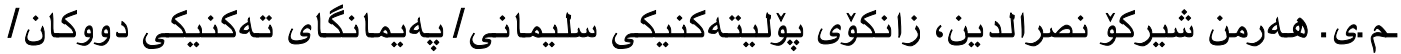

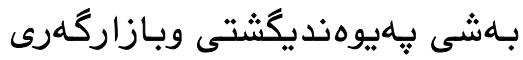

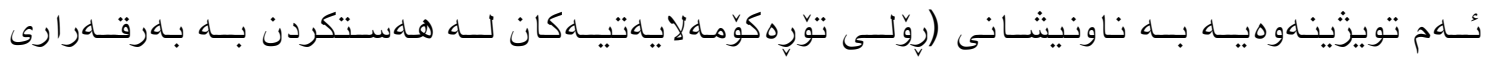

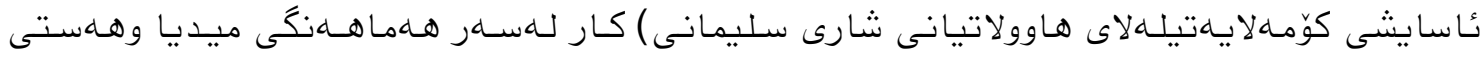

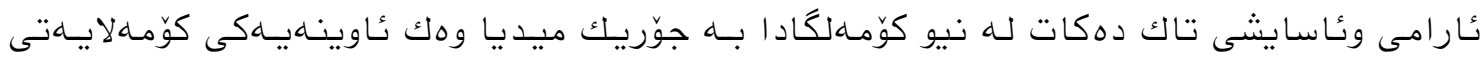

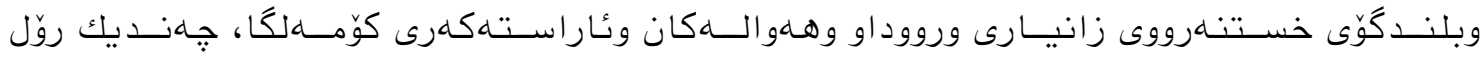

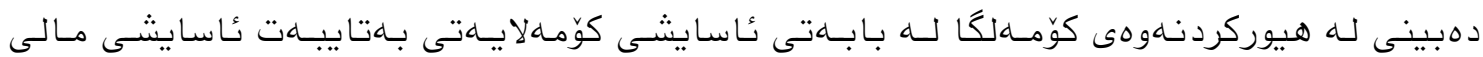

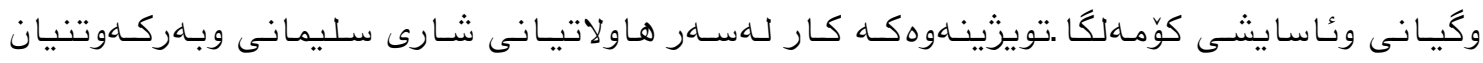

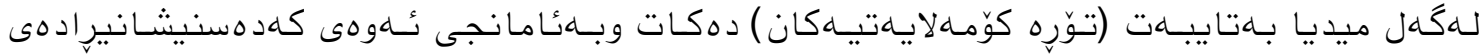

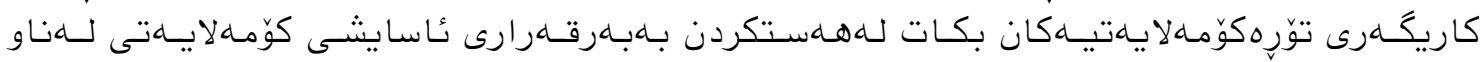

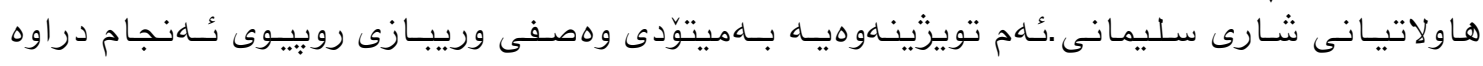

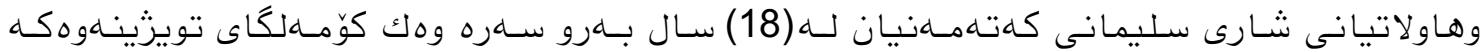

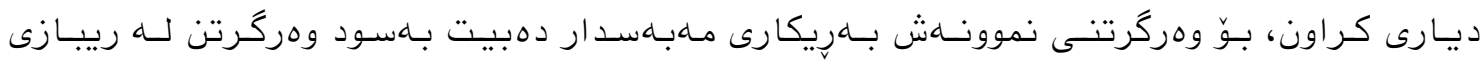

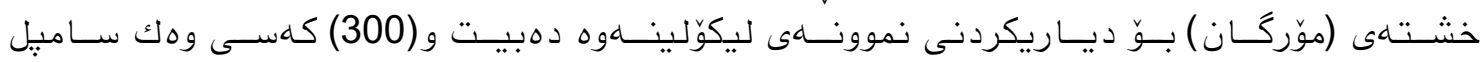

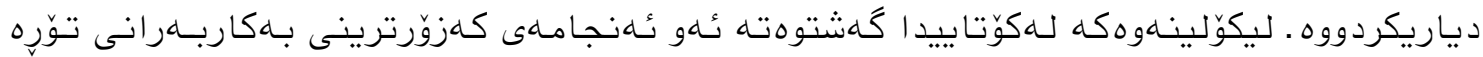

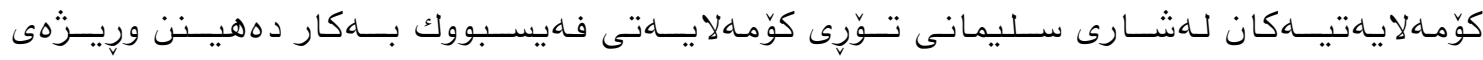

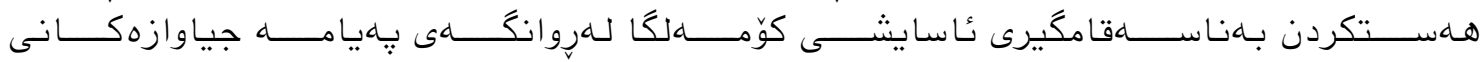

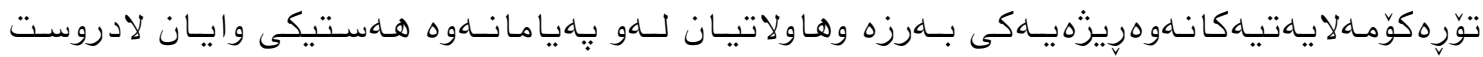

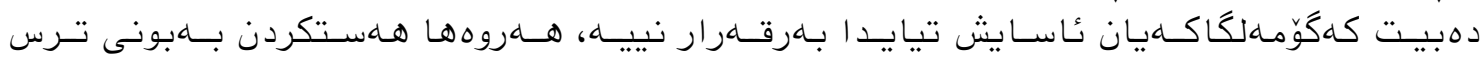

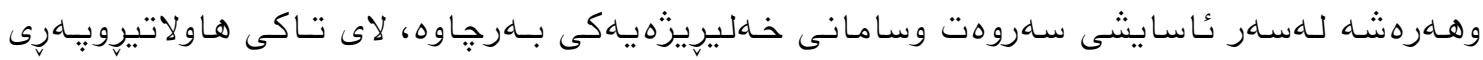

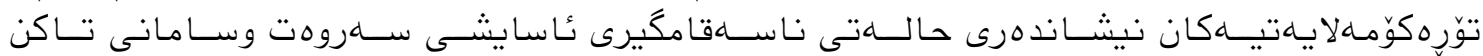

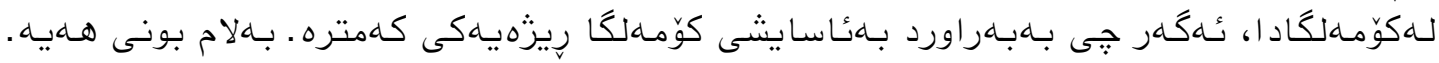




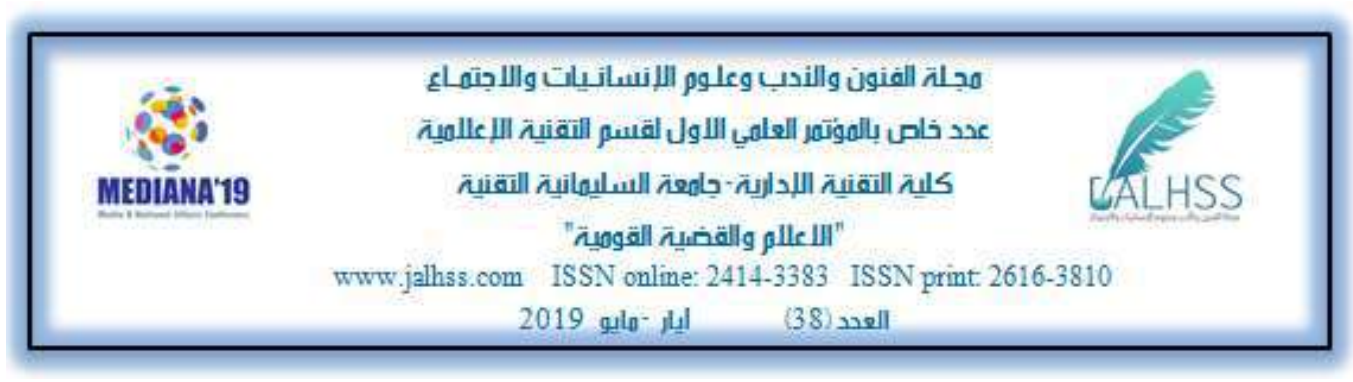

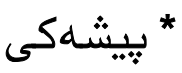

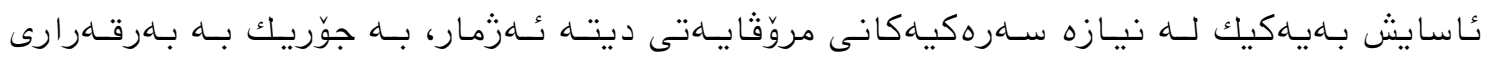

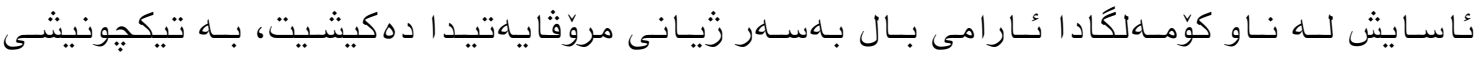

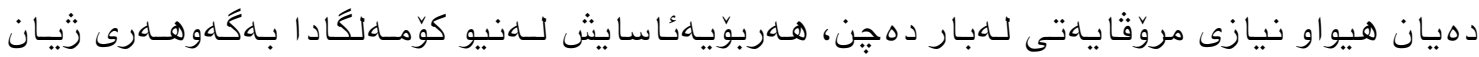

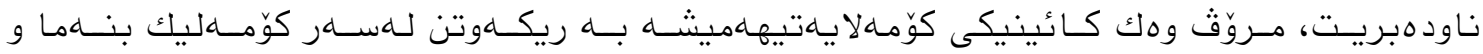

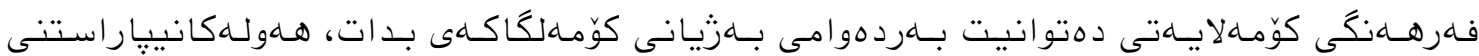

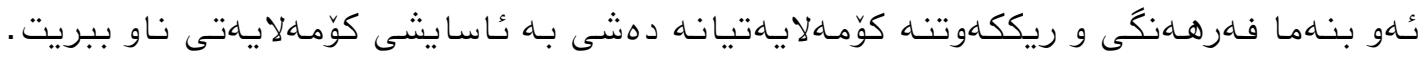

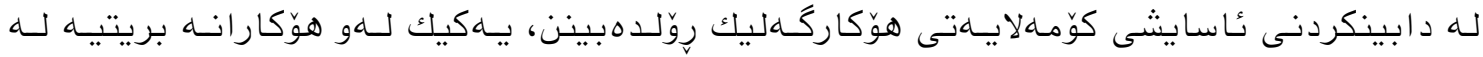

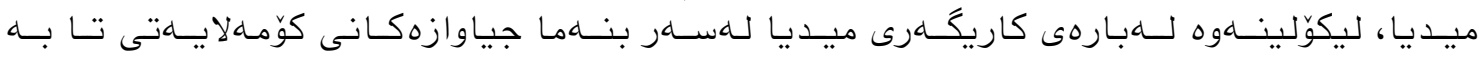

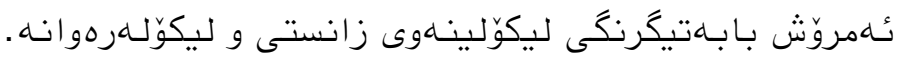

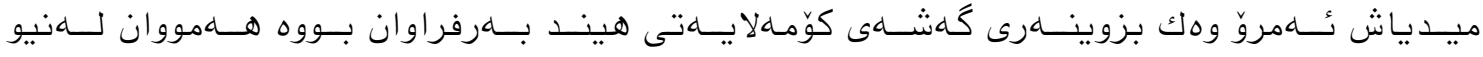

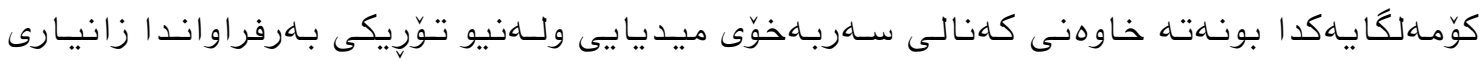

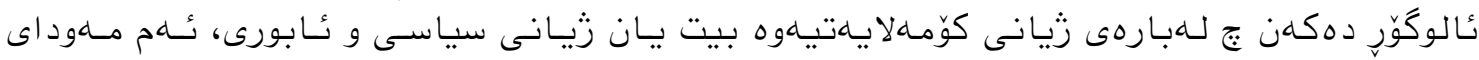

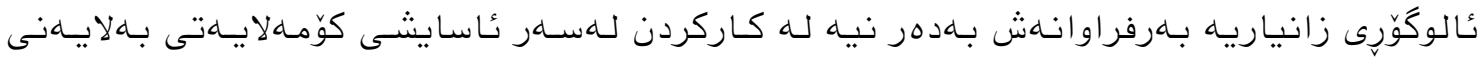

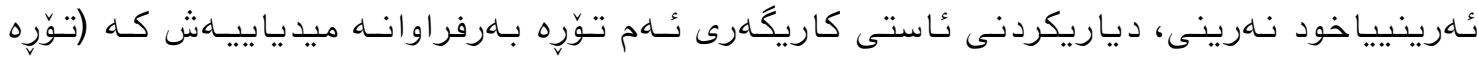

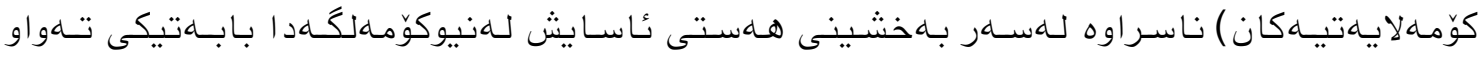

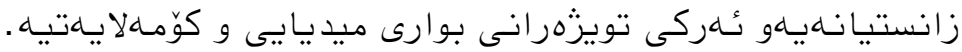

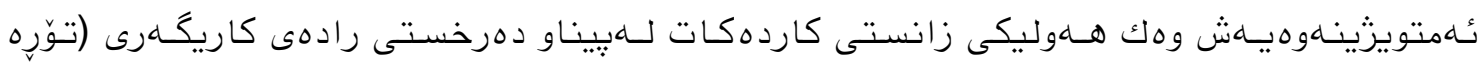

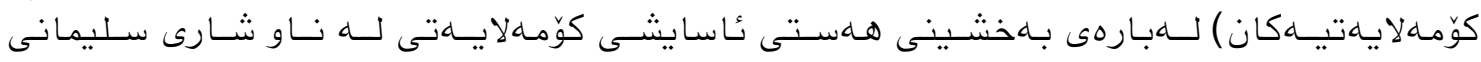

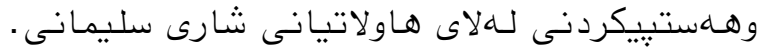




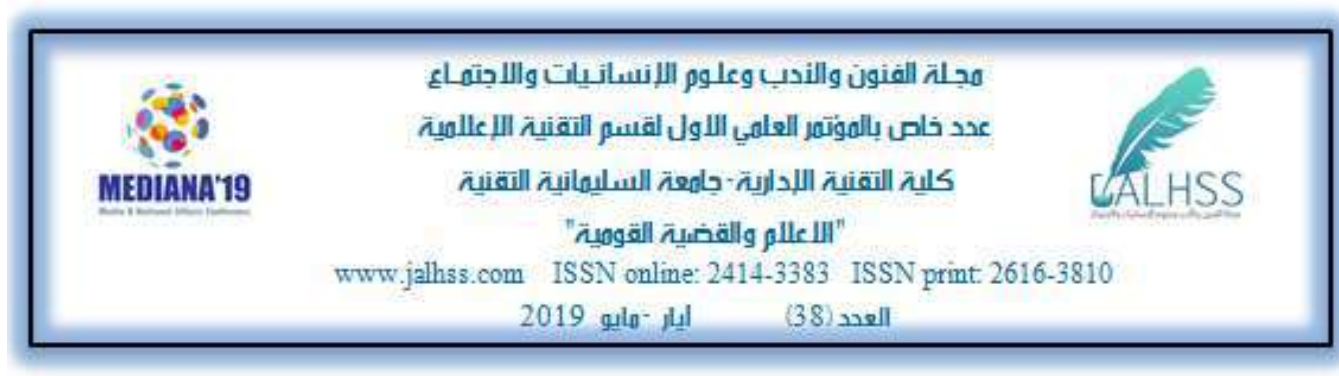

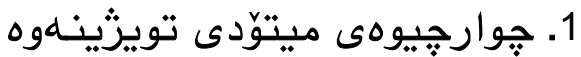

1-1 كيشهى تويزينهلوه

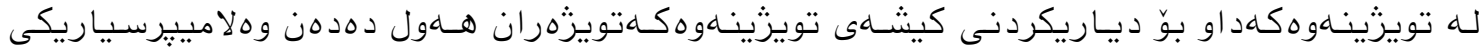

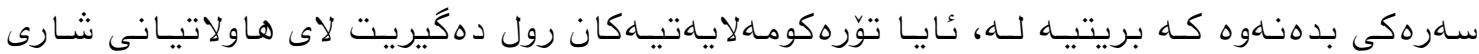

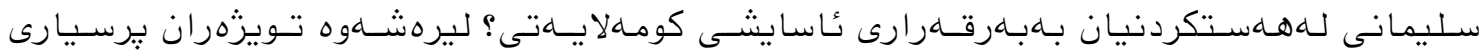

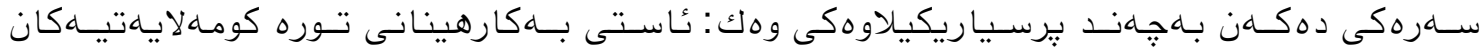

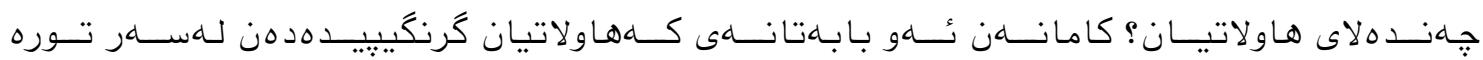

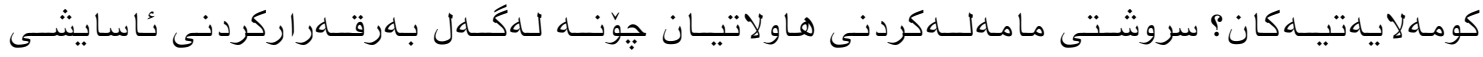

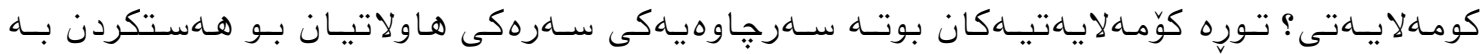

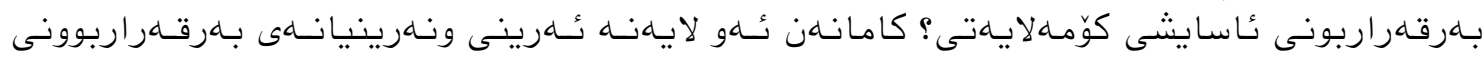

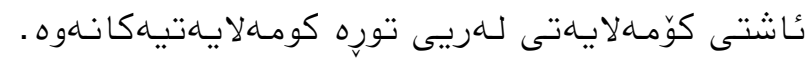

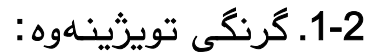

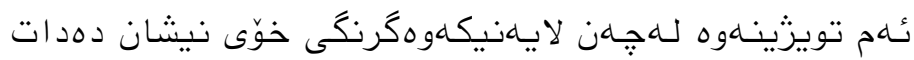

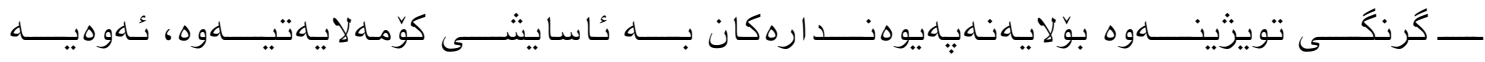

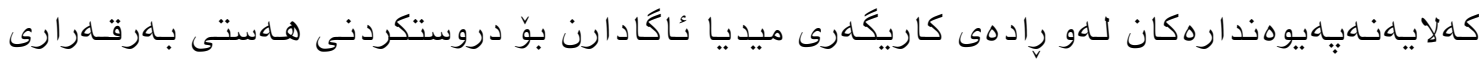

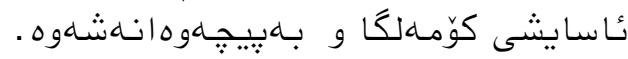

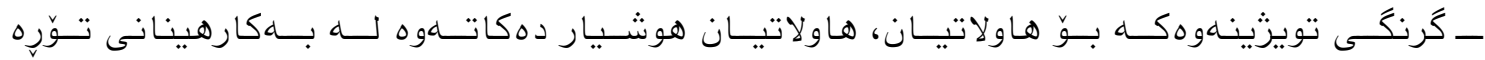

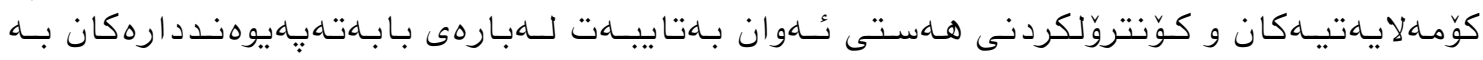

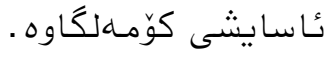

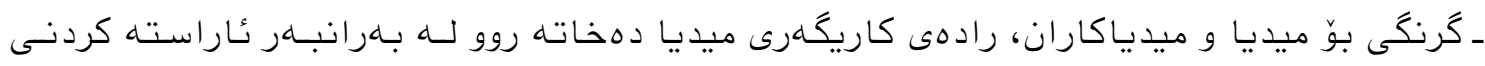

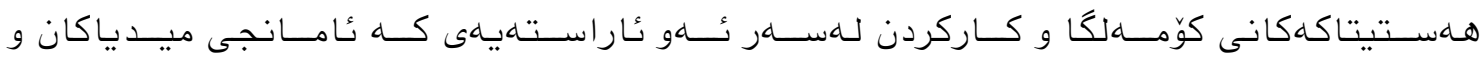

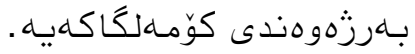

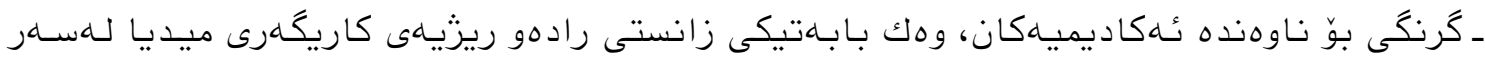

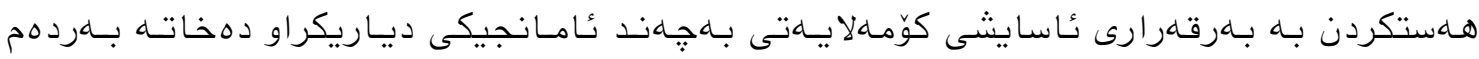
ناوهنده ئهكاد يمينهكان. 


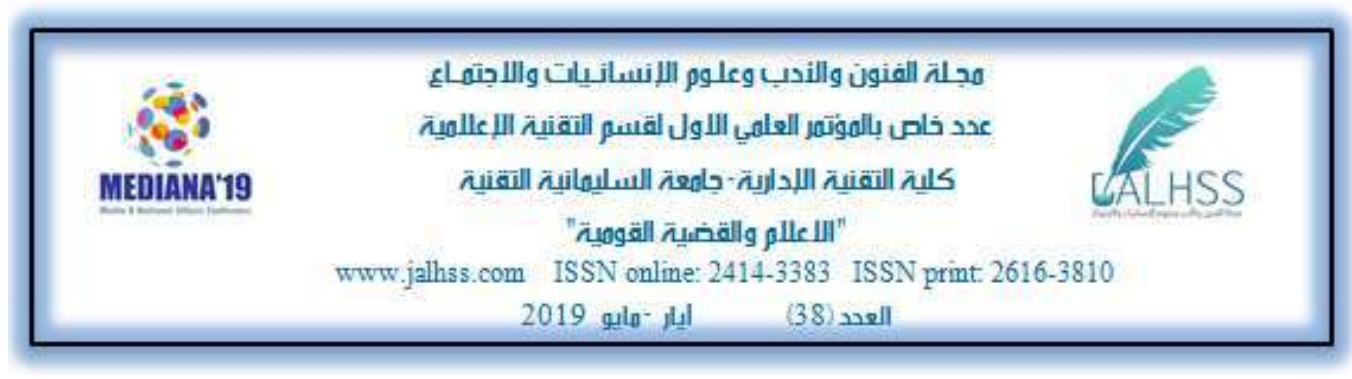

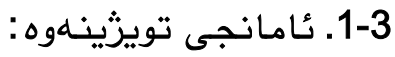

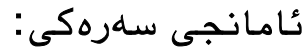

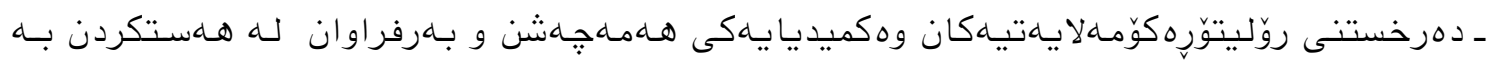

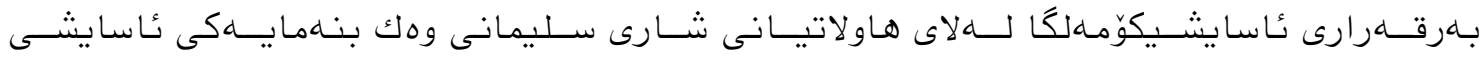

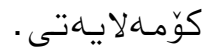

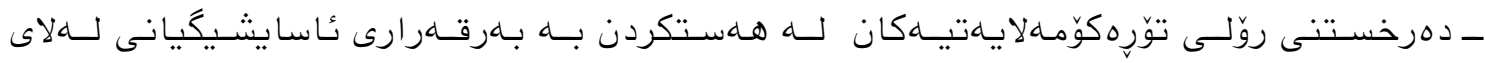

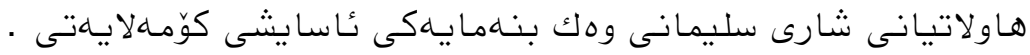

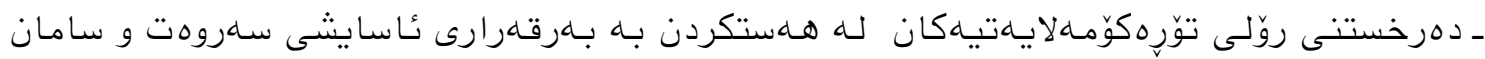

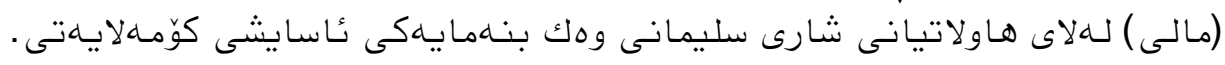
ئامـانجيلاوهكى :

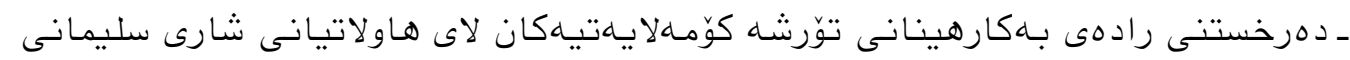

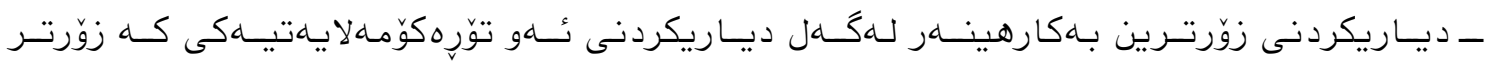
بهارده هينريت

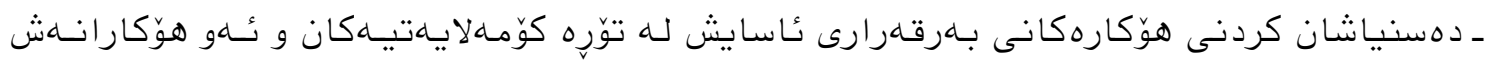

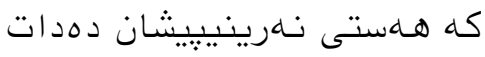

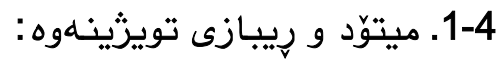

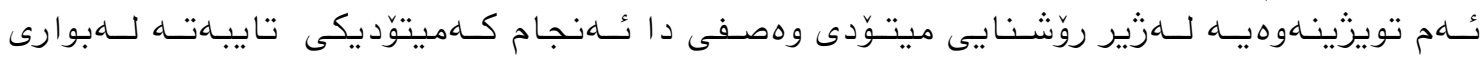

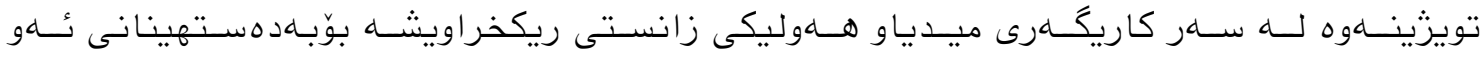

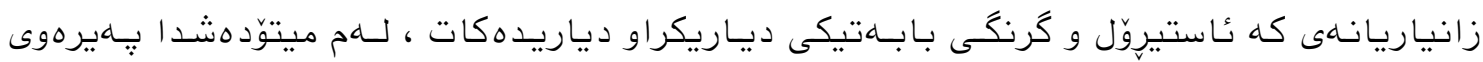

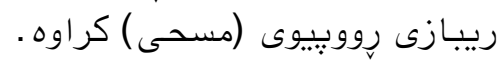

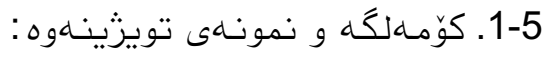

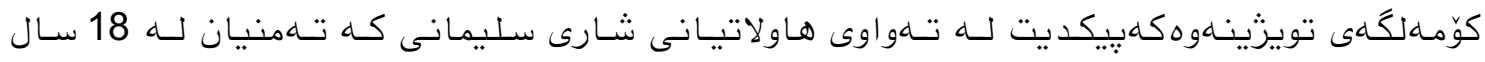

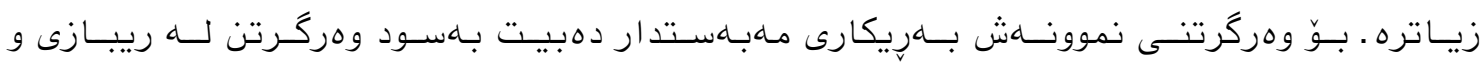

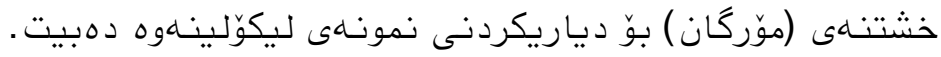

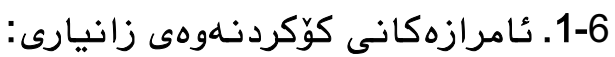

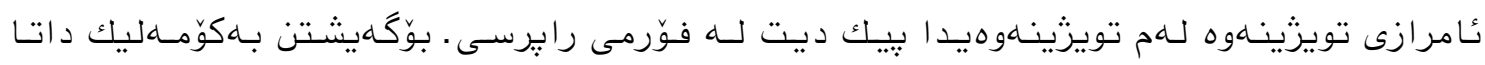

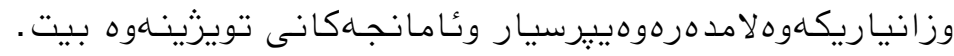




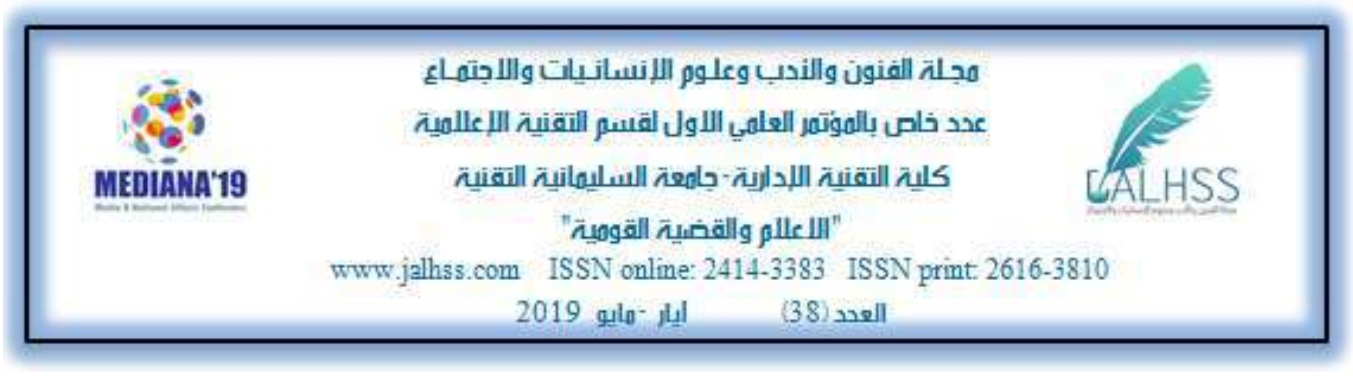

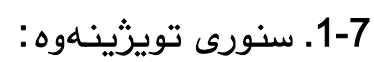

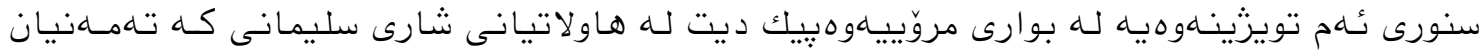

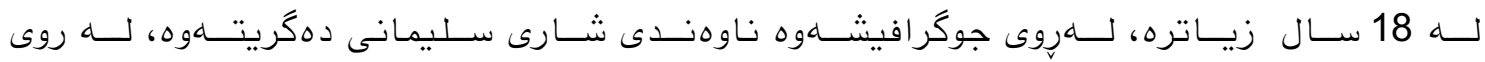

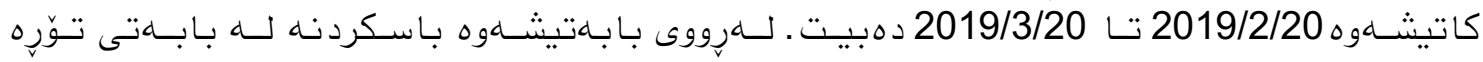

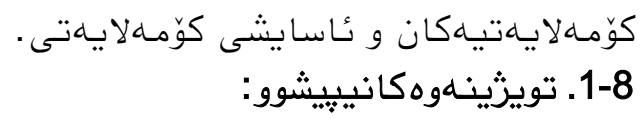

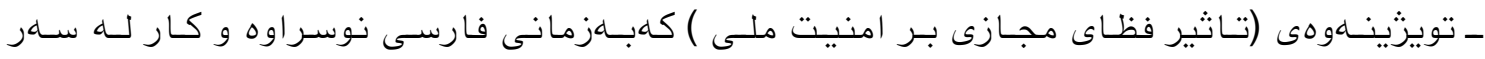

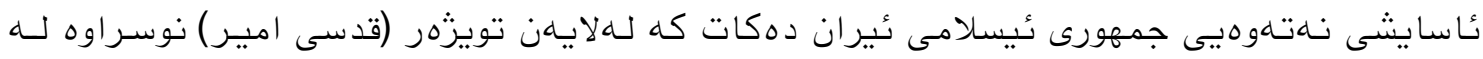

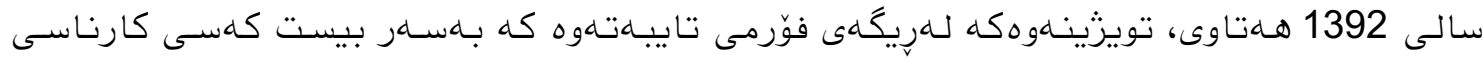

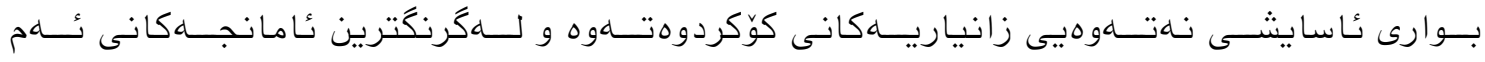

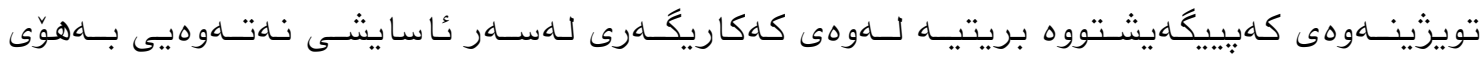

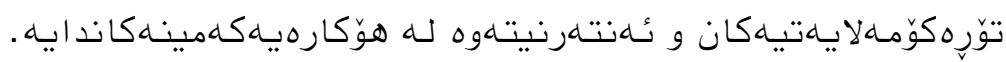

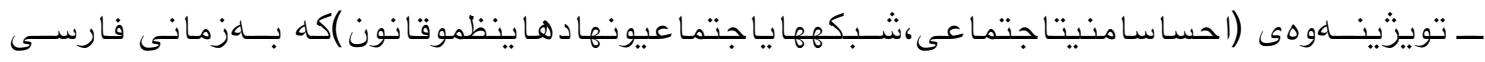

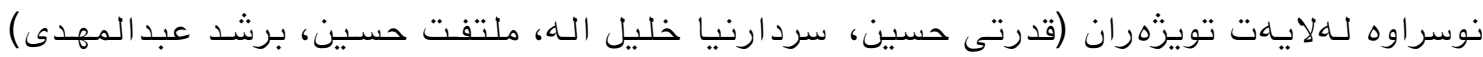

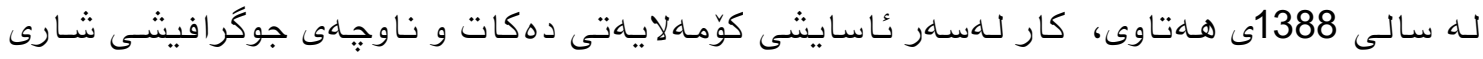

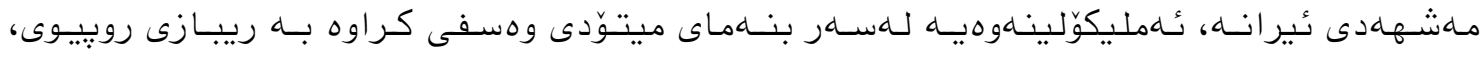

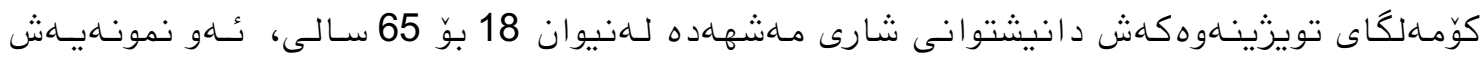

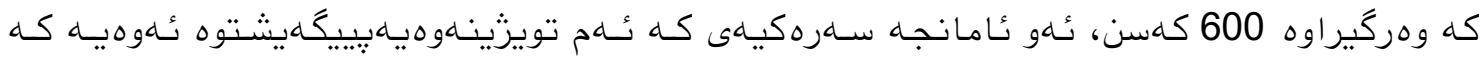

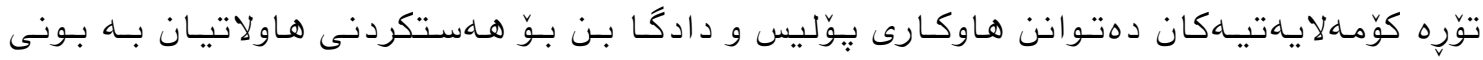

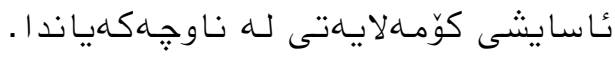

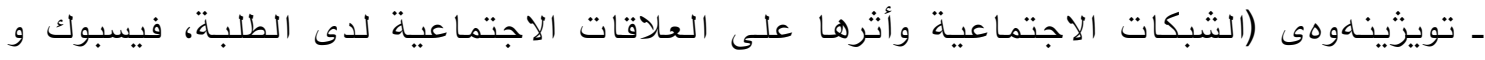

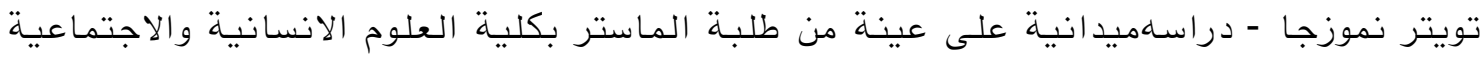

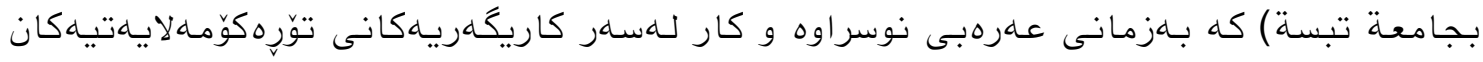

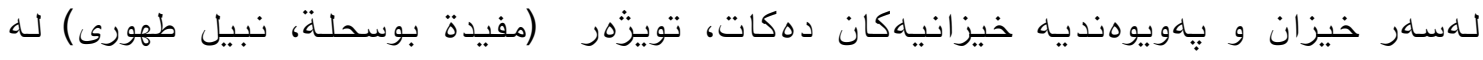

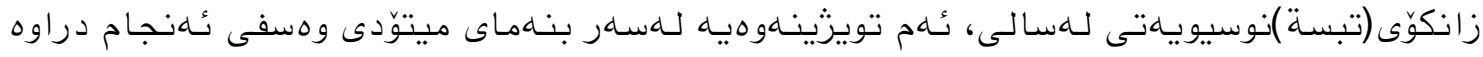

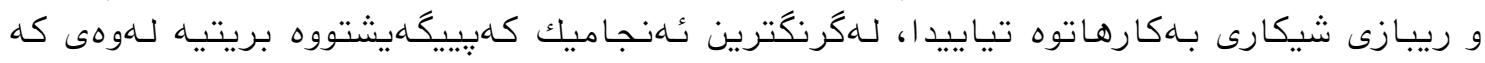

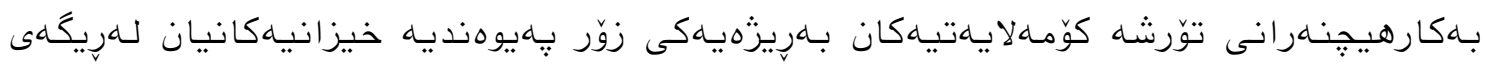

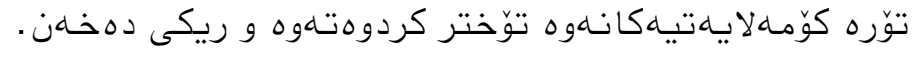




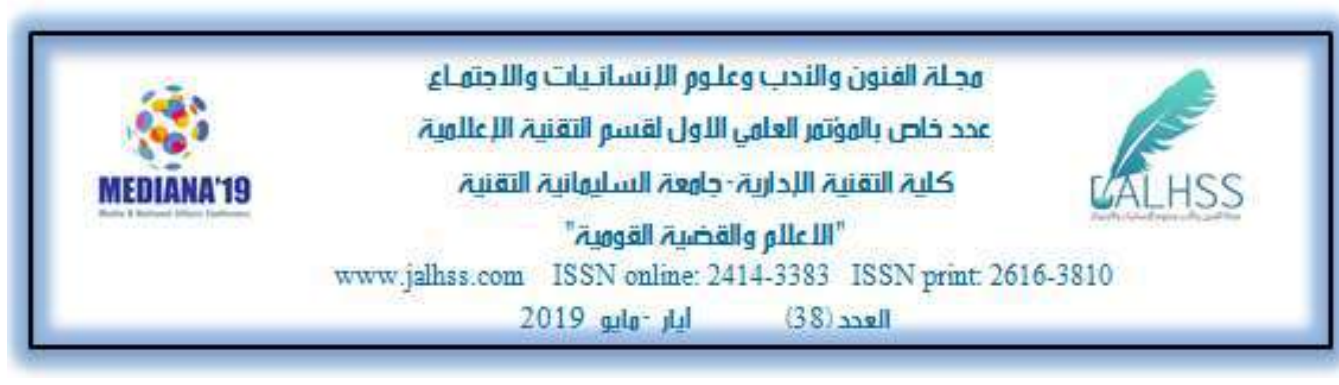

$$
\text { 1-9: راستى و جيكيرى: }
$$

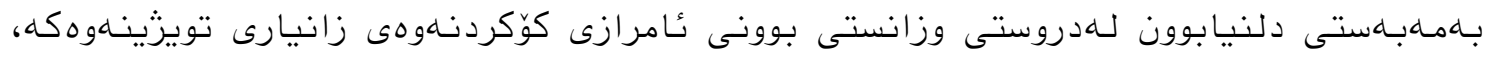

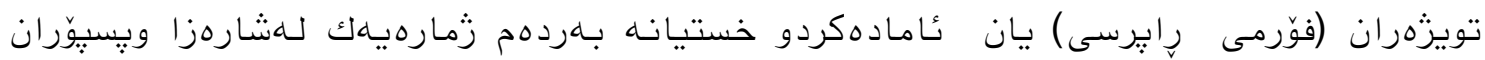

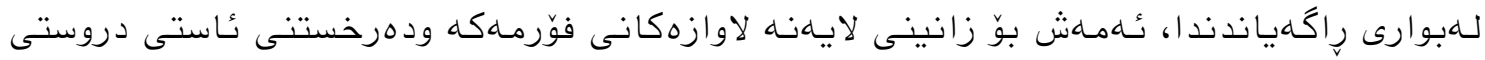

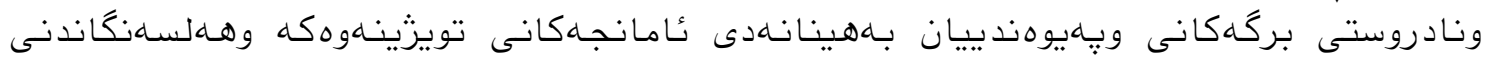

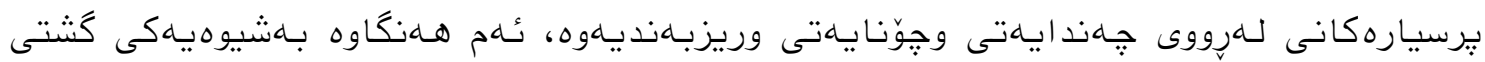

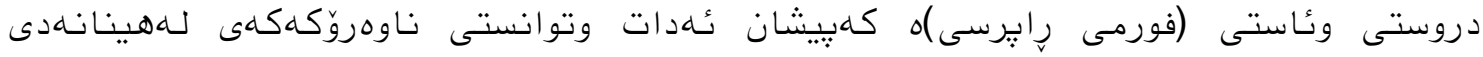

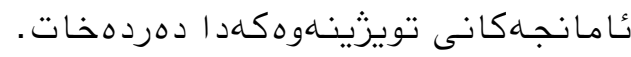

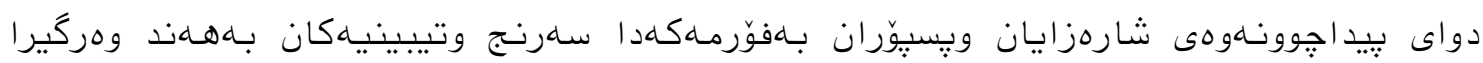

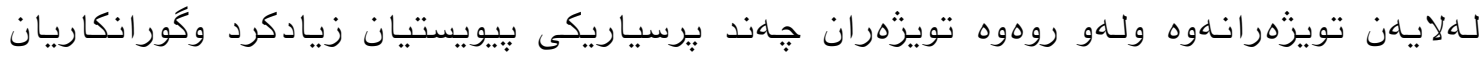

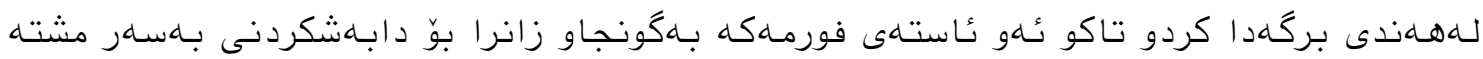

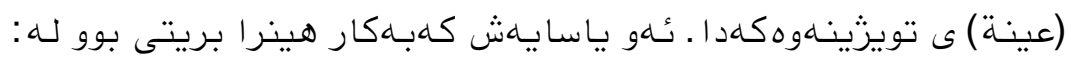

$$
\begin{aligned}
& \text { رجاستى : } \\
& \frac{M * N}{M, N * N} * 100=
\end{aligned}
$$

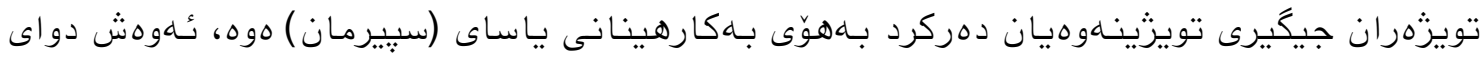

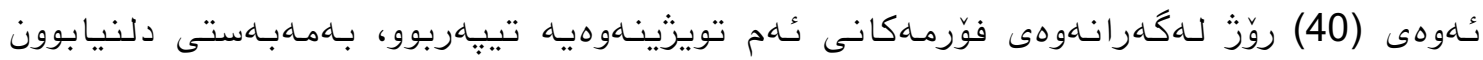

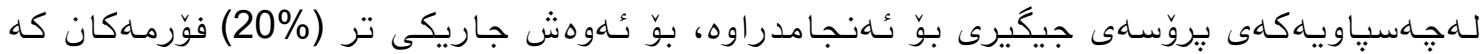

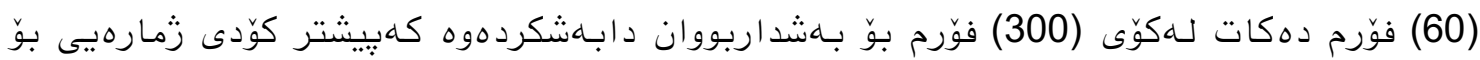

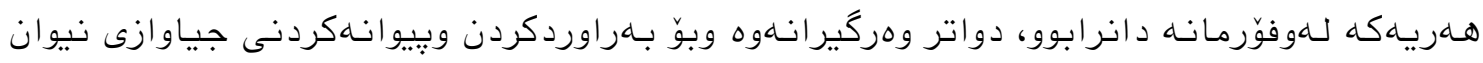

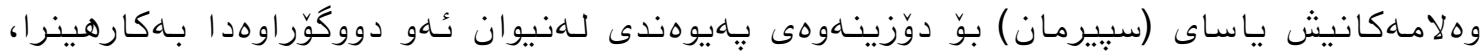

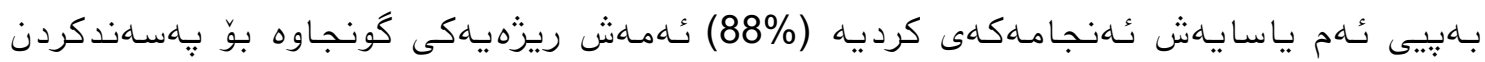

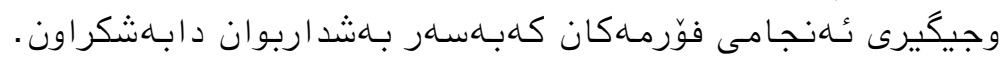
(مهج ف 6

ن ن

$$
\text { باساى سبيِيرمان (ر) = 1- }
$$




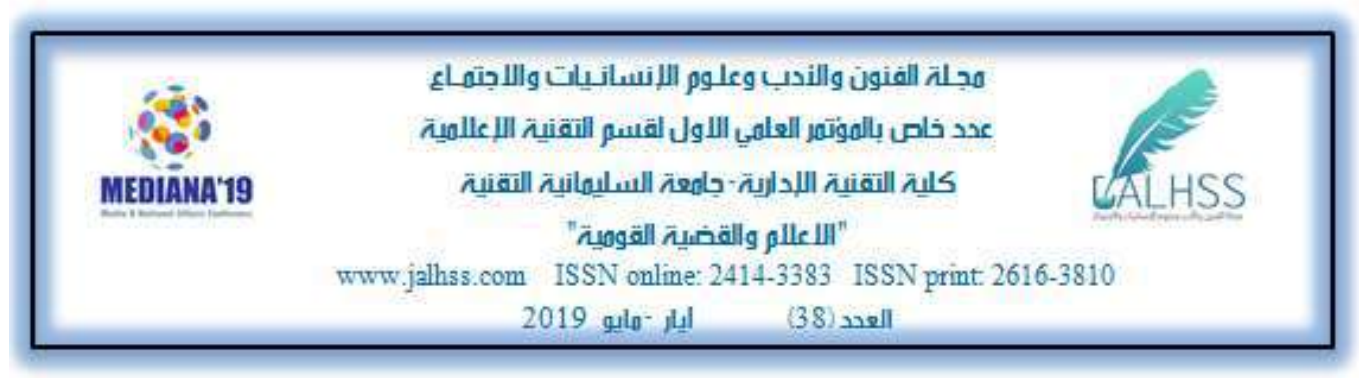

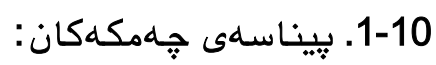

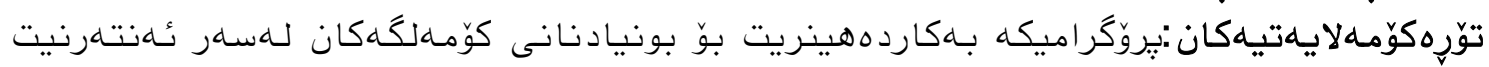

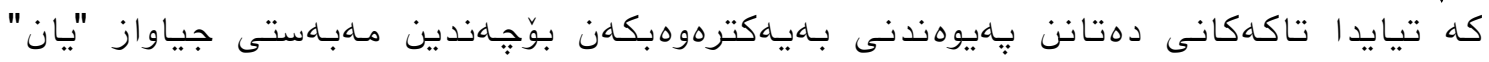

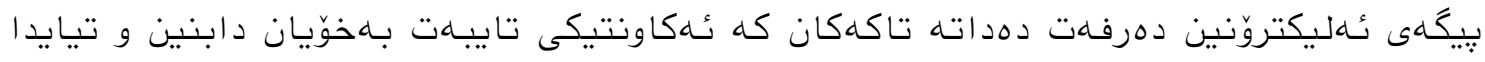

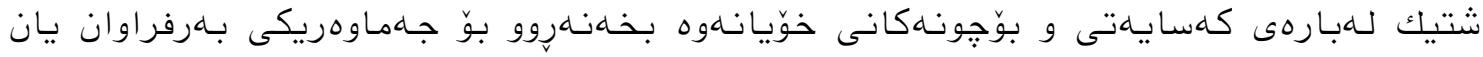

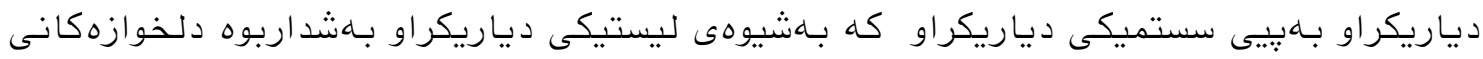

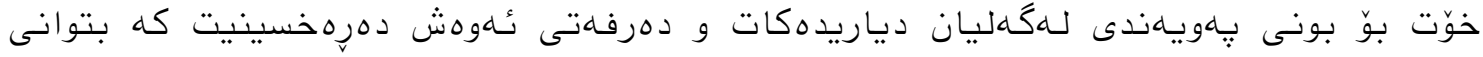

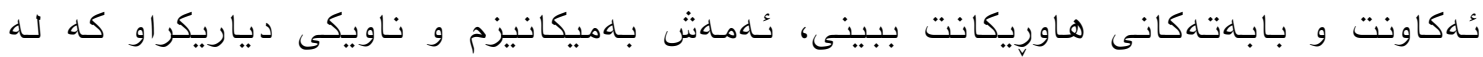

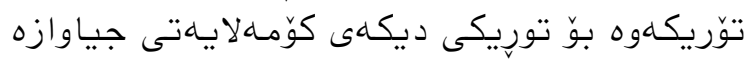

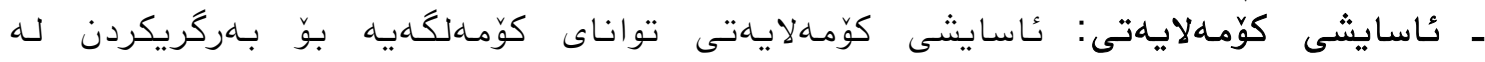

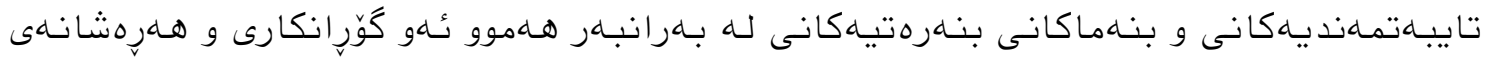

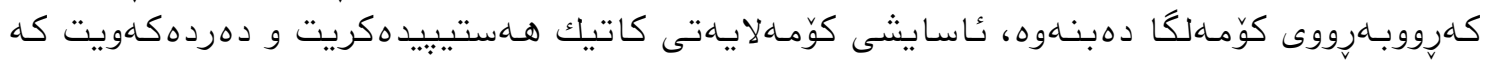

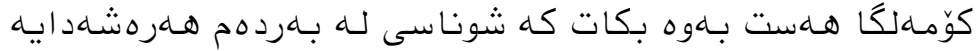

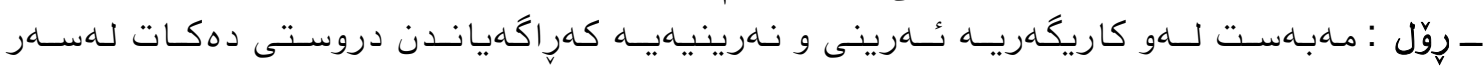

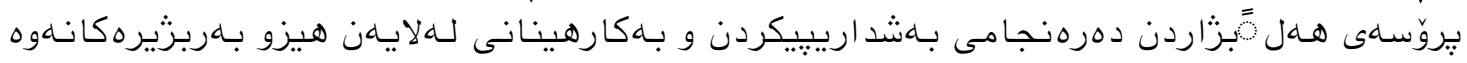

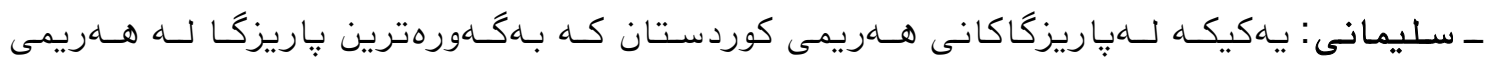

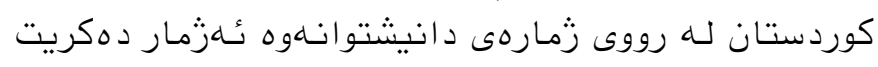




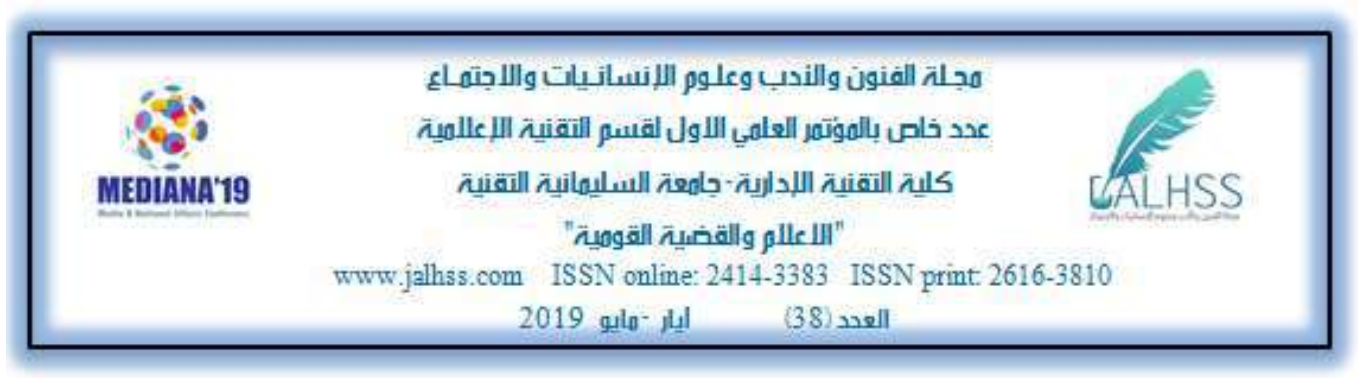

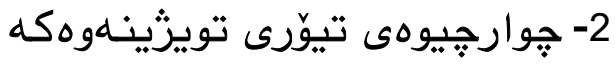

$$
\begin{aligned}
& \text { 2-1. توّره كوّمهلايهتيهكان، كَشهوكردن و كاريگهريهكانى. }
\end{aligned}
$$

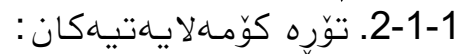

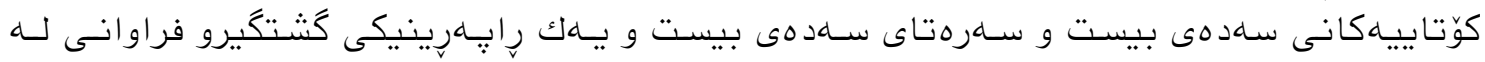

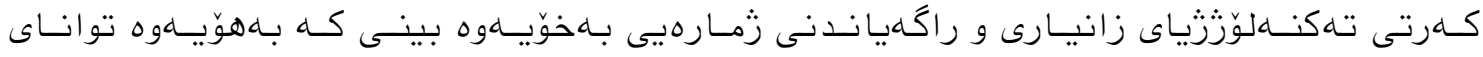

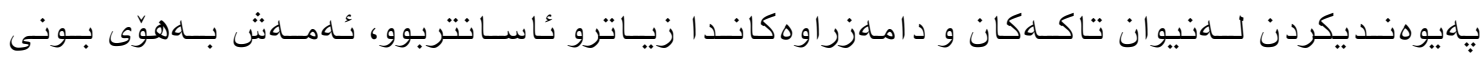

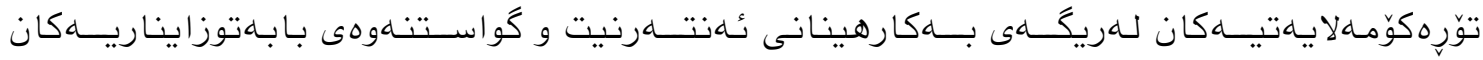

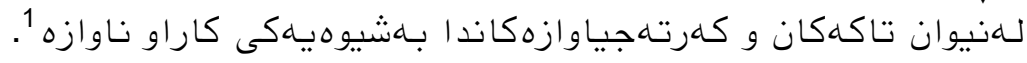

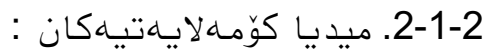

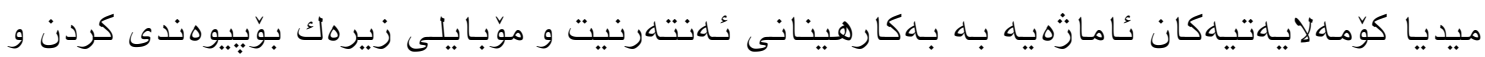

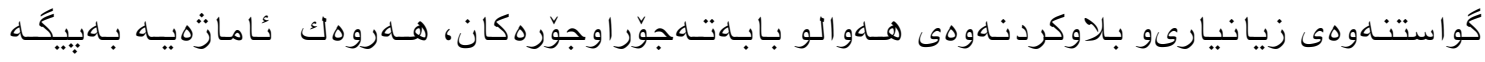

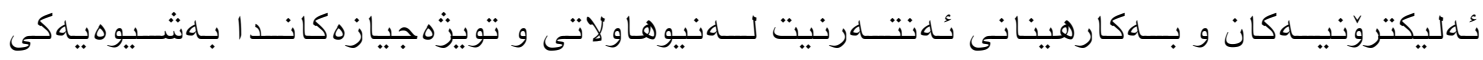

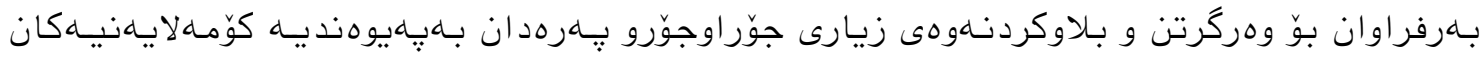

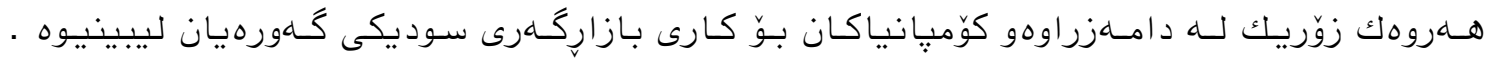

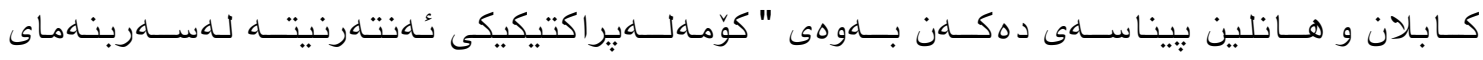

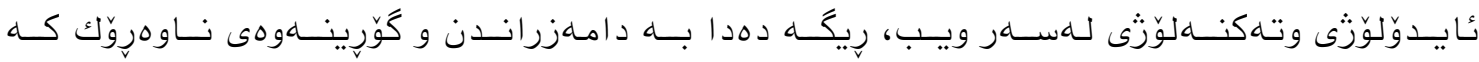

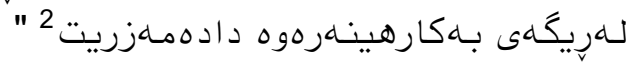

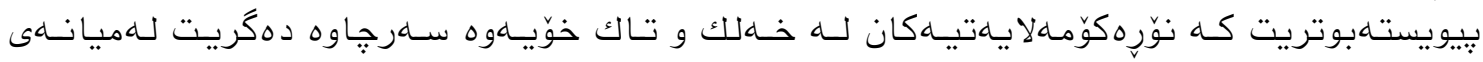

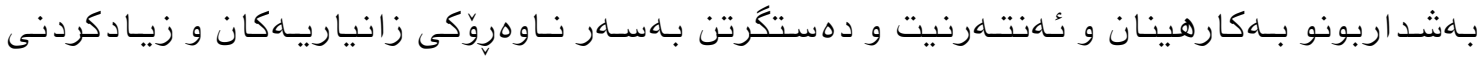

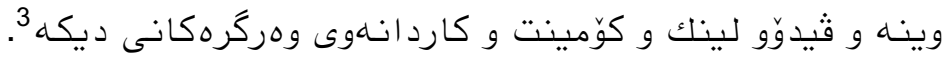

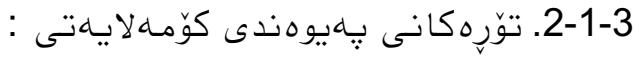

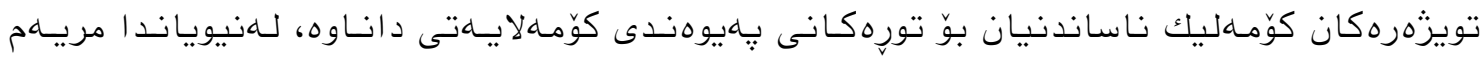

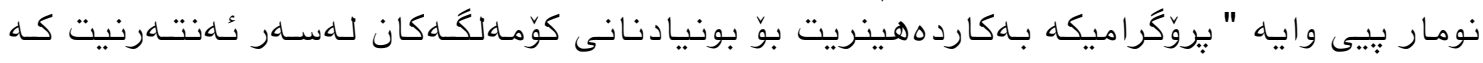

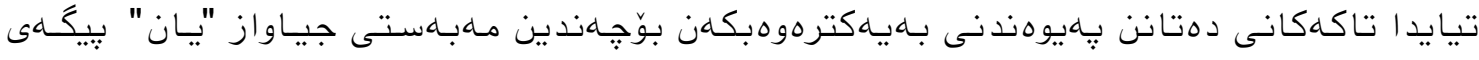

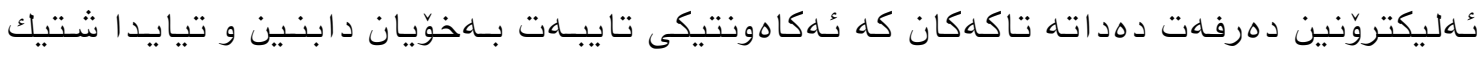

1. باقر ساروخانى، جامعة شناسي ارطباتات، تهران، انتشارات اطلاعات، 1376، ل 148

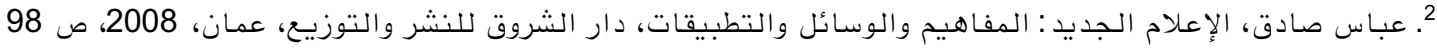

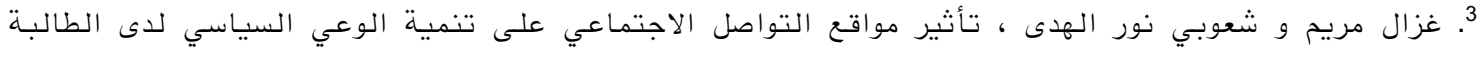

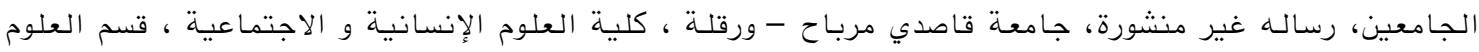

الإنسانية، 2014 2014، لـ 20

DOI: $10.33193 /$ JALHSS.38.5 


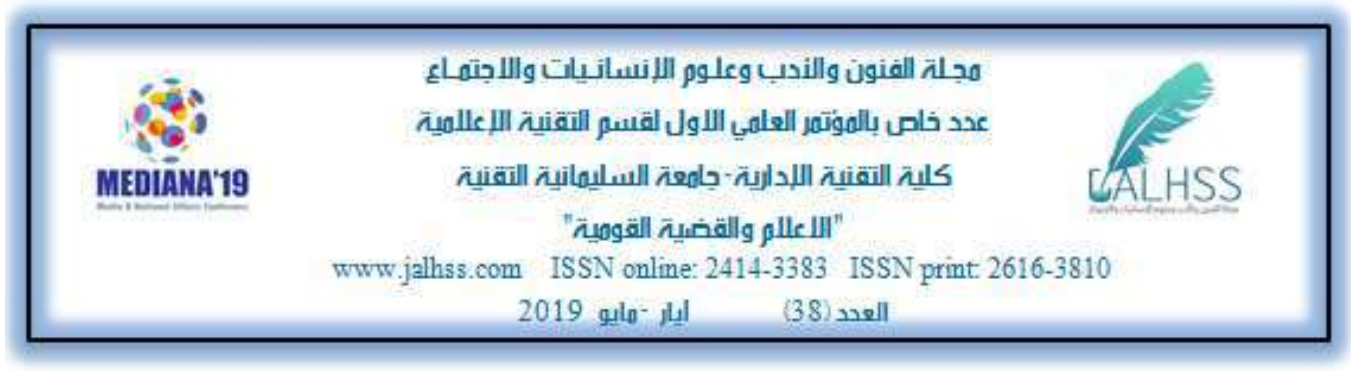

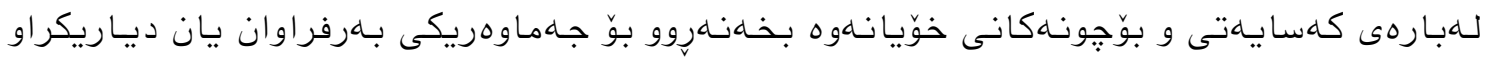

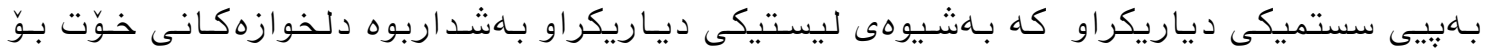

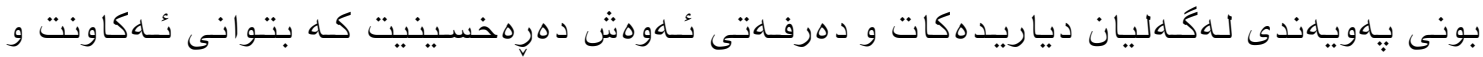

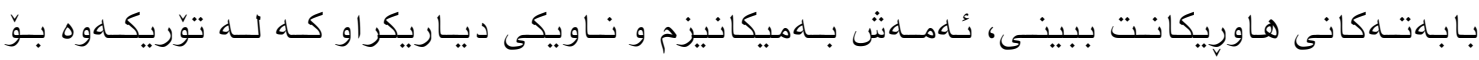

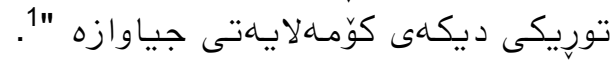

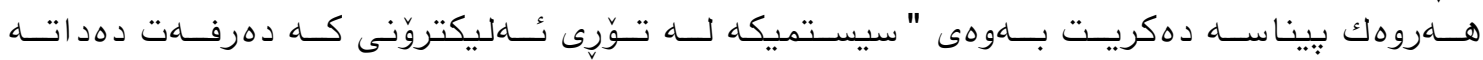

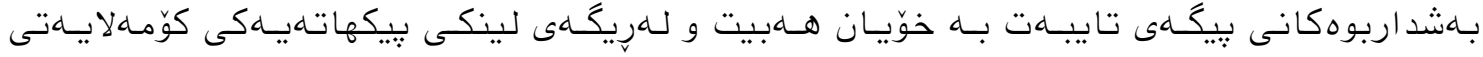

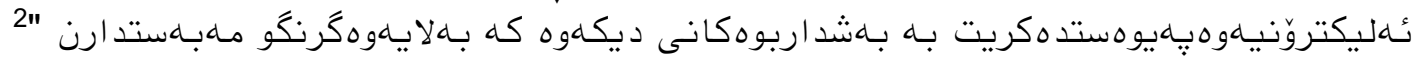

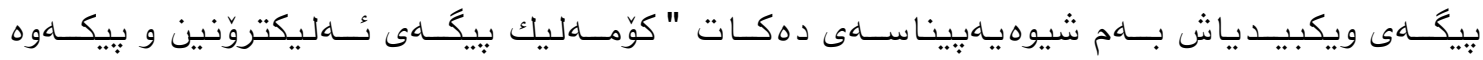

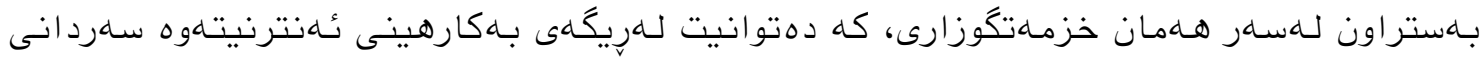

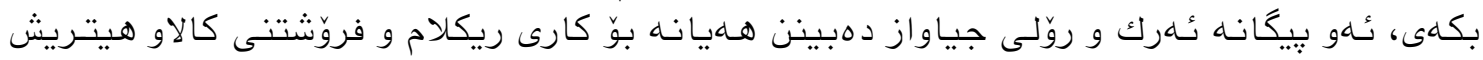

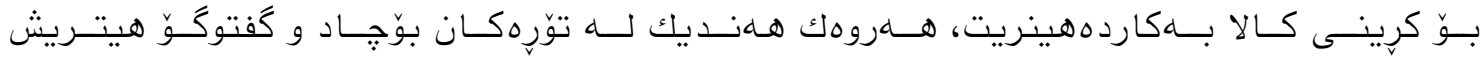

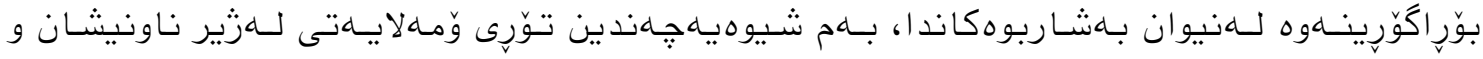

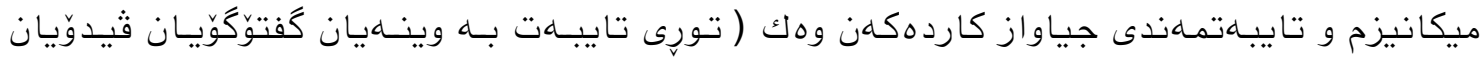

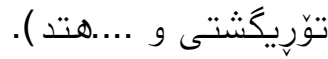

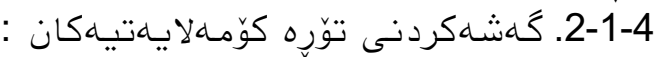

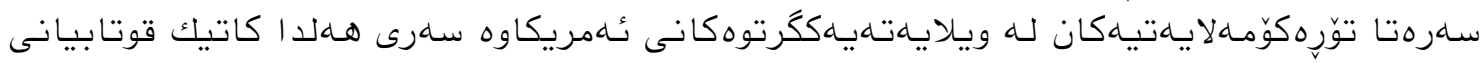

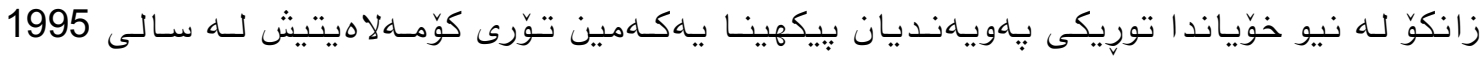

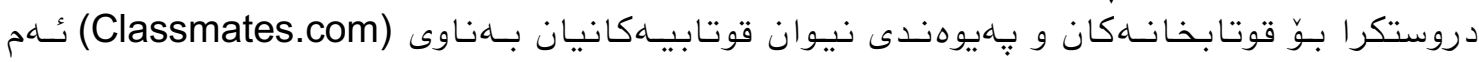

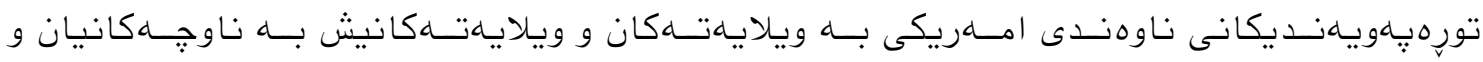

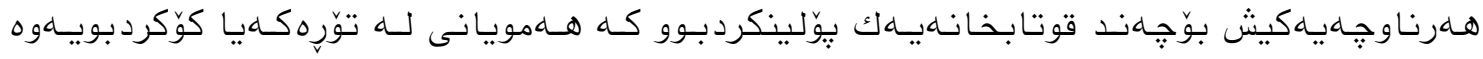

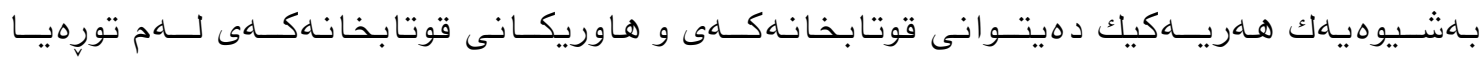

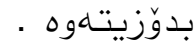

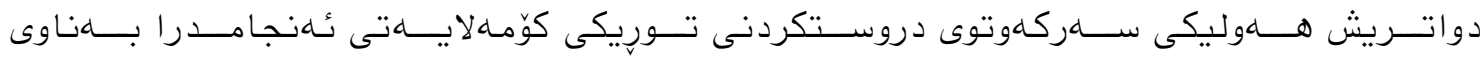
(SixDegrees.com)

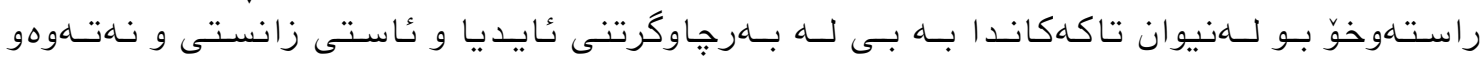

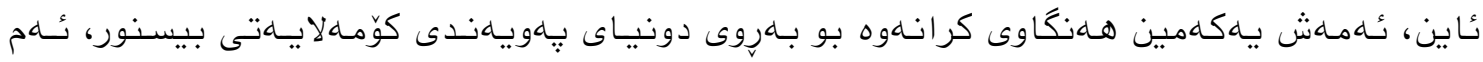

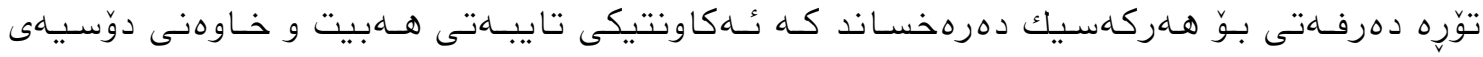

1. عباس صادق، الإعلام الجديد: المفاهيم والوسائل والتطبيقات، دار الشروق للنشر والتوزيع، عمان، 2008، ص 98

2.

DOI: $10.33193 /$ JALHSS.38.5 


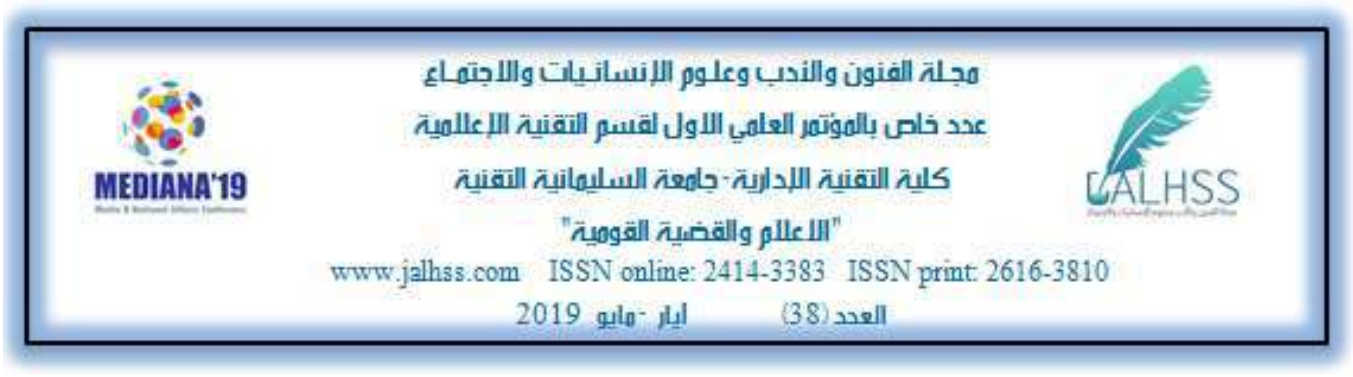

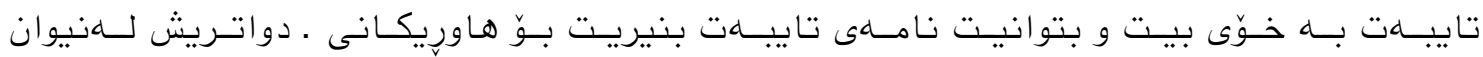

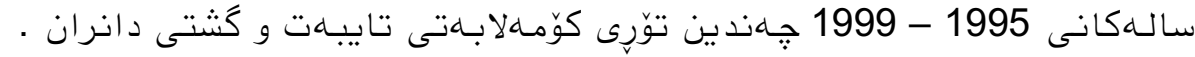

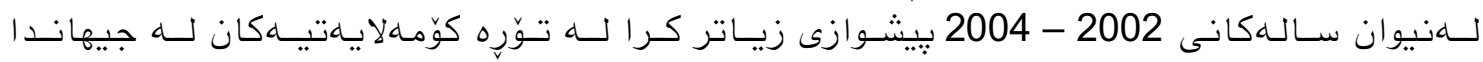

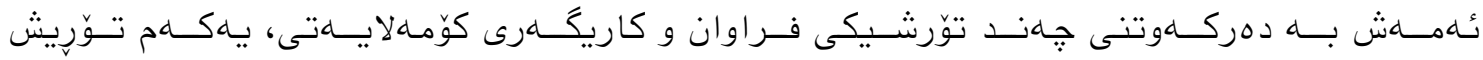
(Friendster)

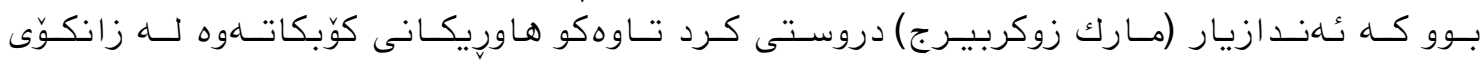

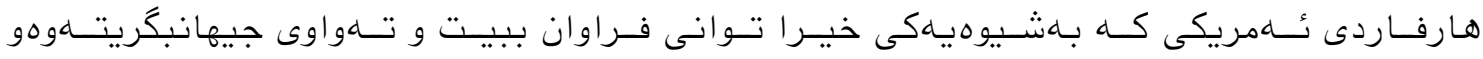

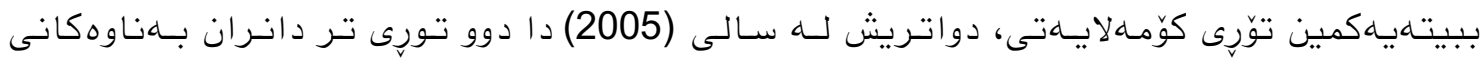

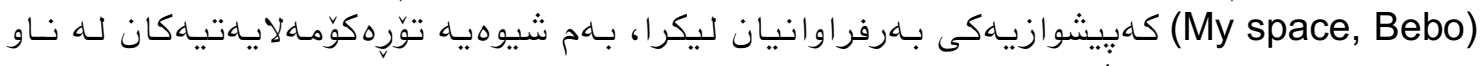

$$
\begin{aligned}
& \text { توّرى ئهنترنيتدا زوَربون } 1 \text { ـ . }
\end{aligned}
$$

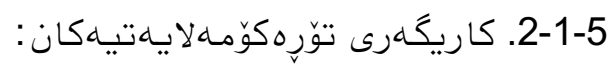

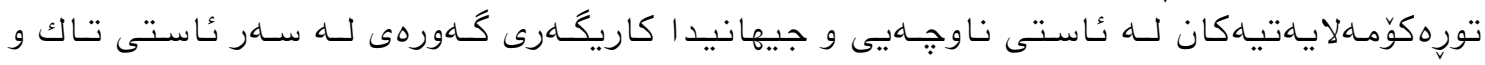

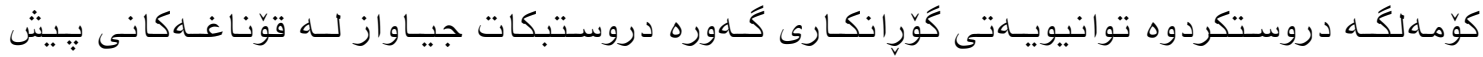

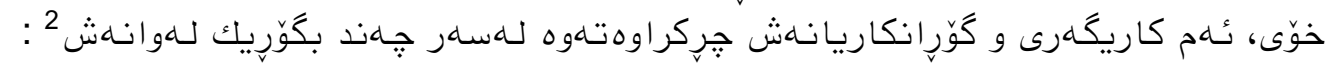

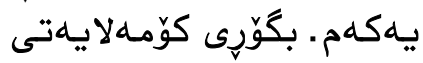

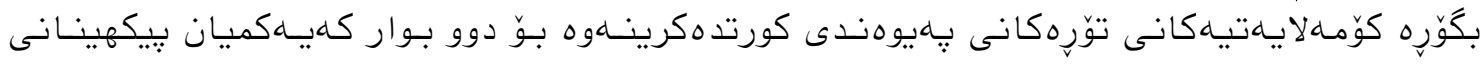

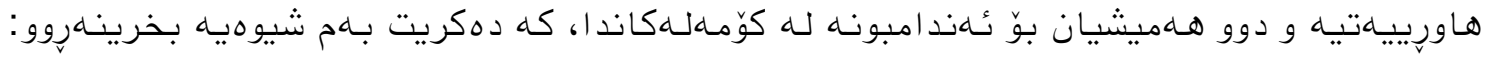

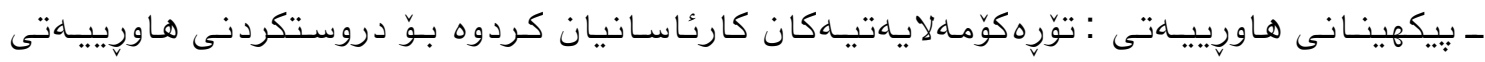

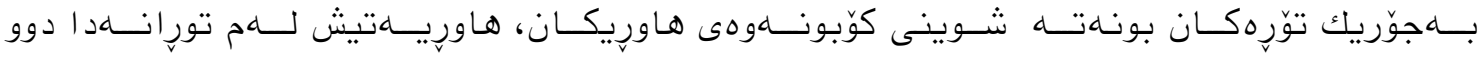

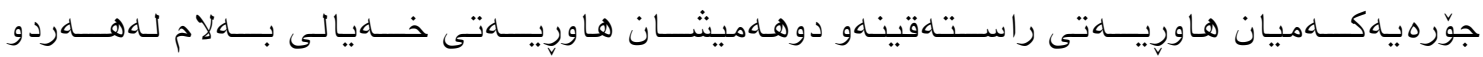

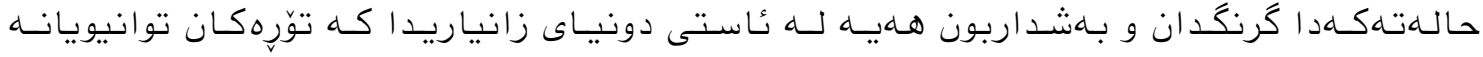

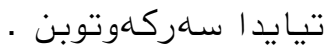

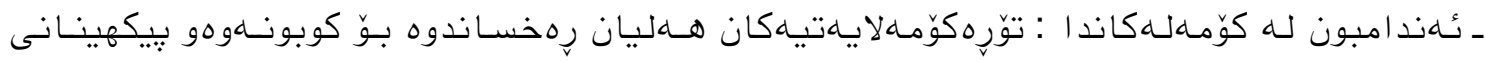

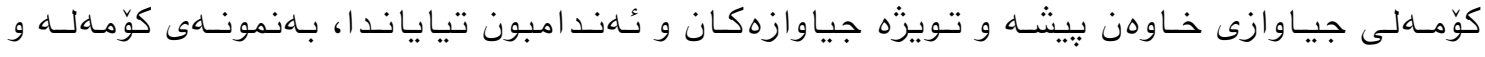

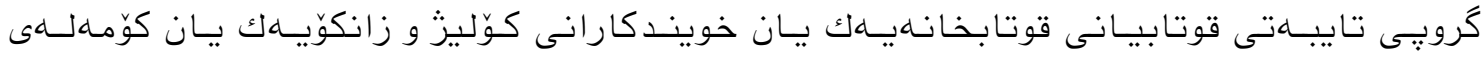

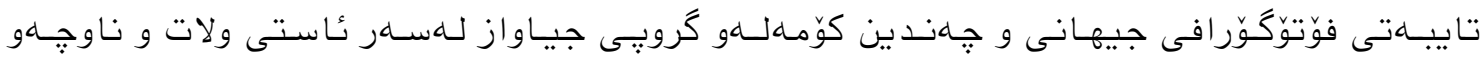
ج.يهان

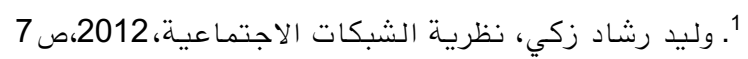

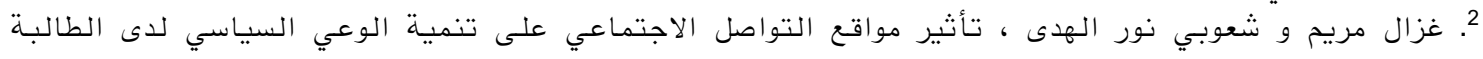

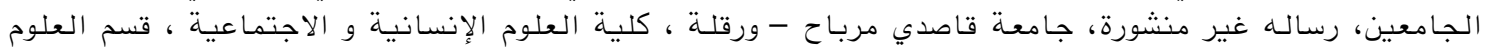

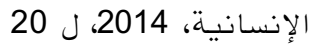

DOI: $10.33193 /$ JALHSS.38.5 


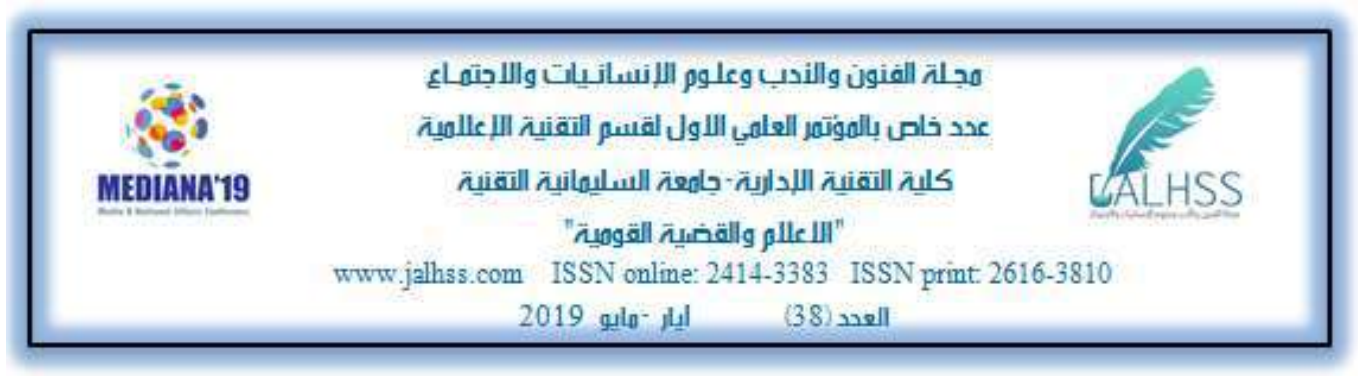

$$
\text { دووهم · بكوَّره سياسيهكان: }
$$

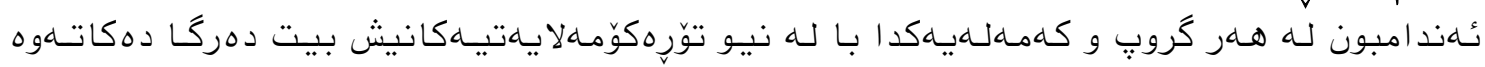

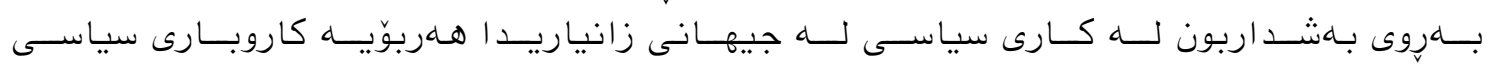

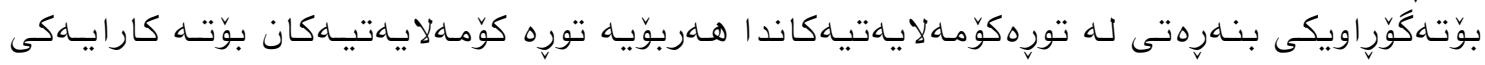

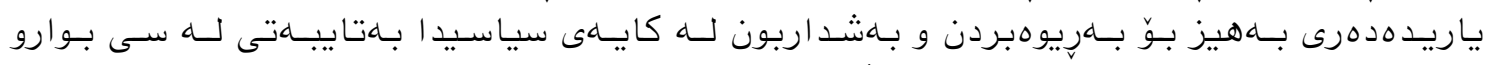

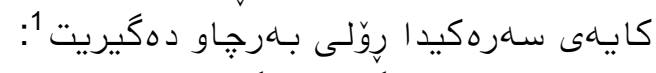

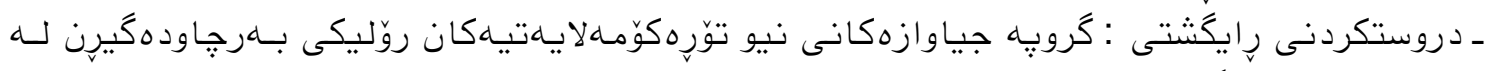

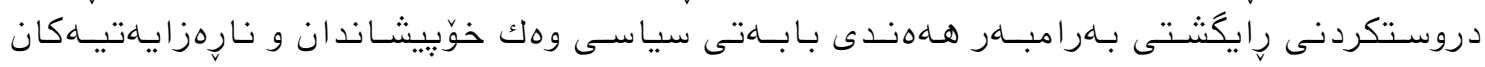

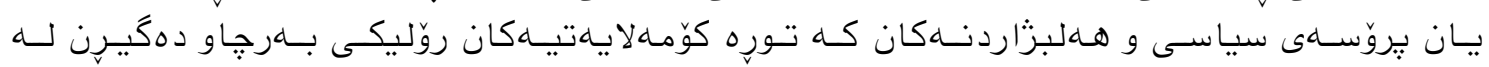

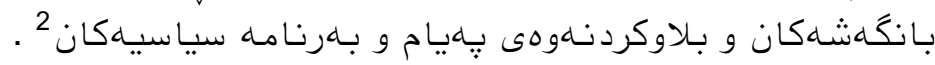

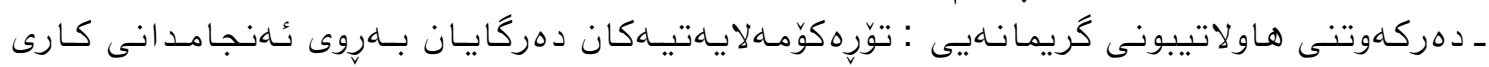

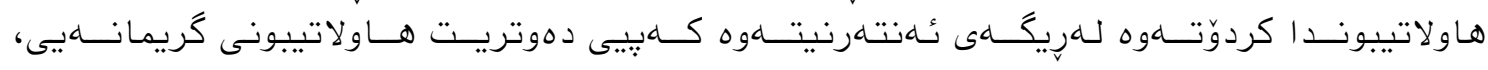

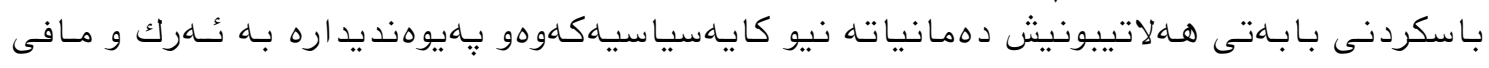

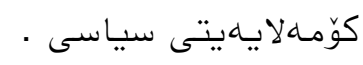

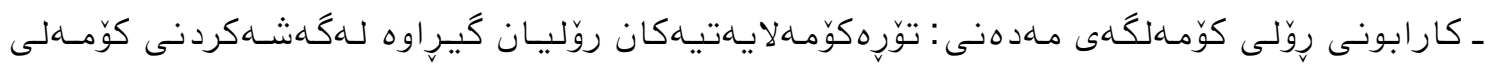

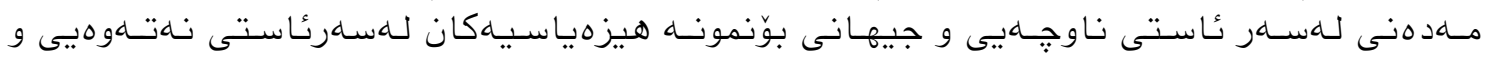

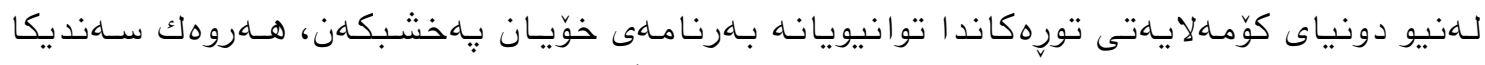

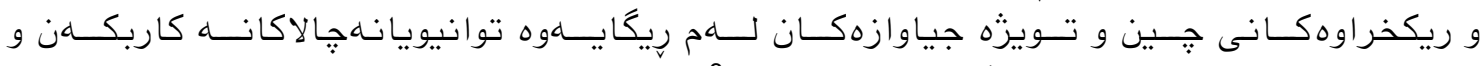

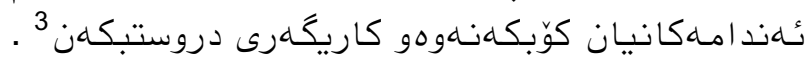

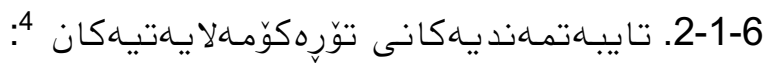

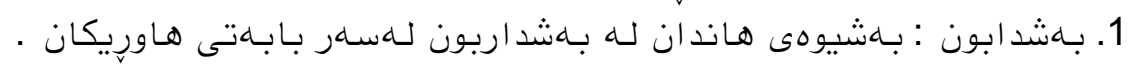

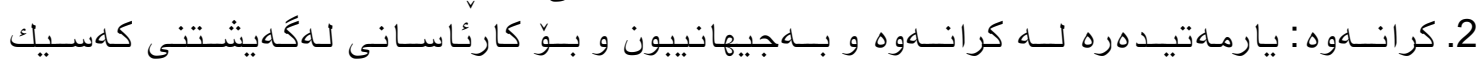

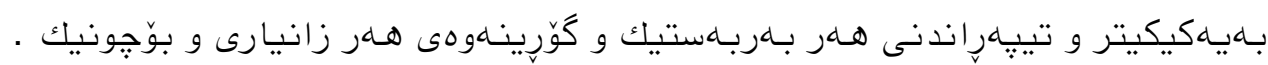

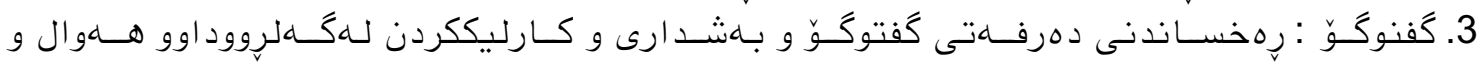
زانياريه كدا 4. ناردنى نامه : دهرفهـتى ناردن و وهركرتنى نامه لـهنيوان دووكهسيبهيوهنديد ار .

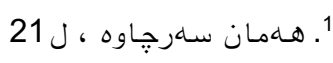
2. محمد أبو عامود، الاتصال بالجماهير وصنع القرار السياسي ، دار الشروق للنشر والتوزيع القاهرة، 2001، ص 143

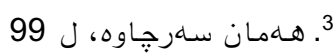

$$
\begin{aligned}
& \text { 4. إبراهيمأحمد الدوي، شبكاتوهات وفالتواصلالاجتماعي، 2016، ص } 5
\end{aligned}
$$

DOI: 10.33193/JALHSS.38.5

88 


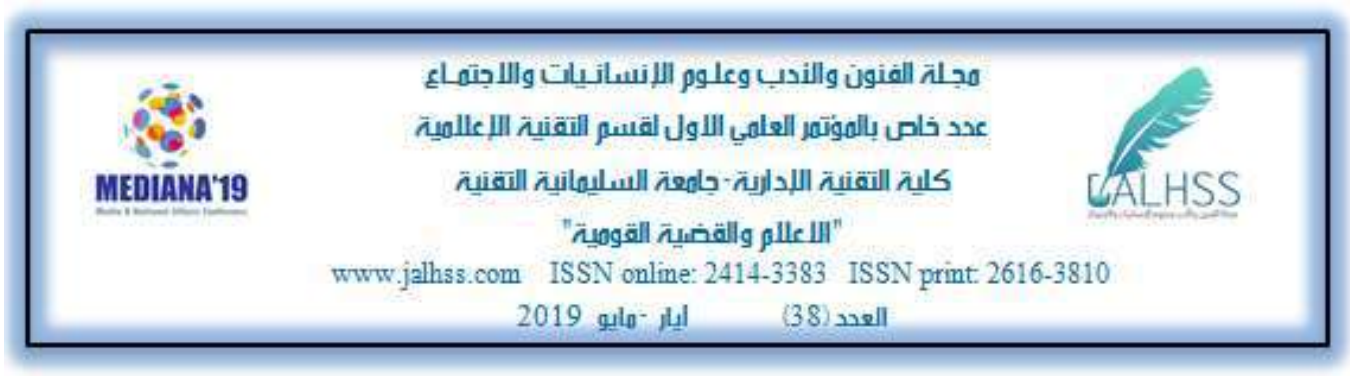

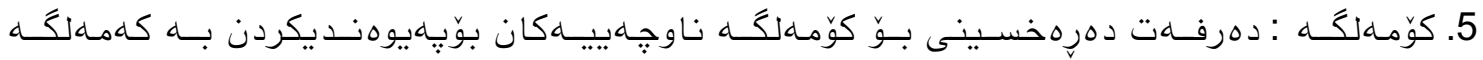

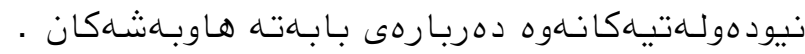

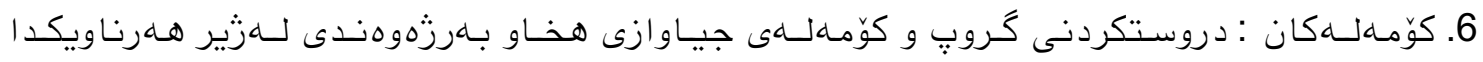
كdبت كون

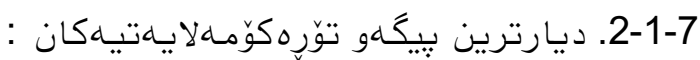
يهكهم. فيسبووك facebook:

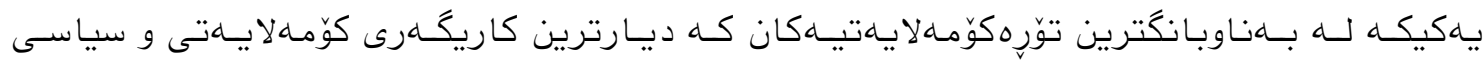

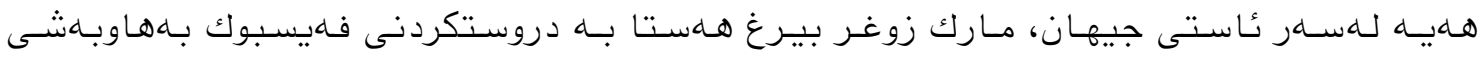

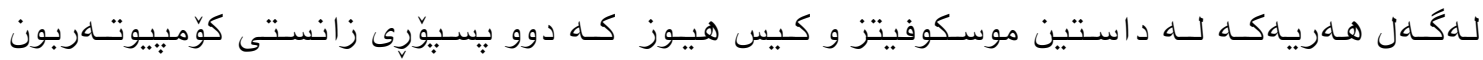

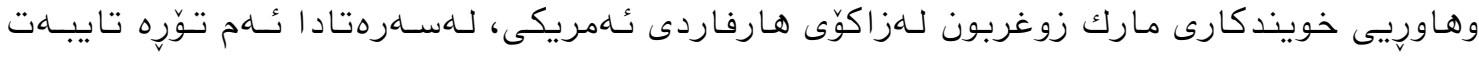

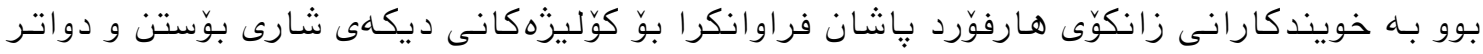

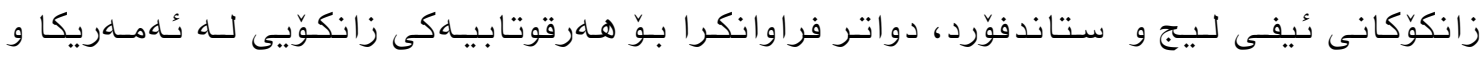

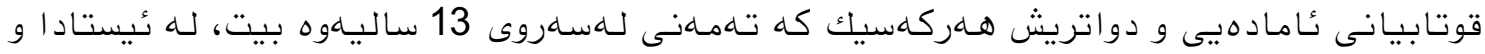

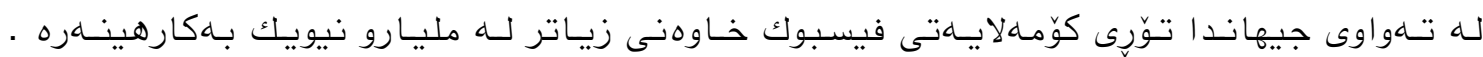

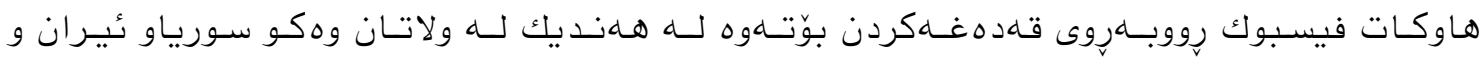

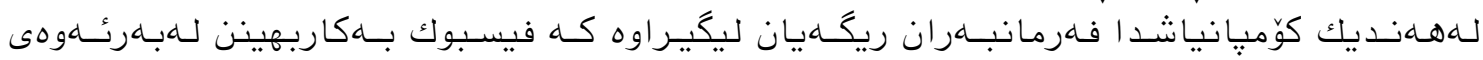

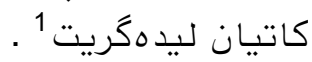

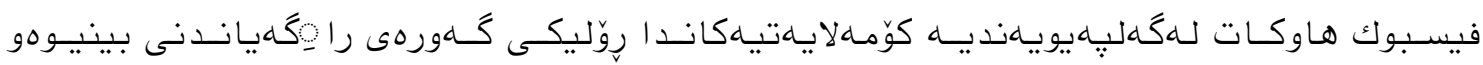

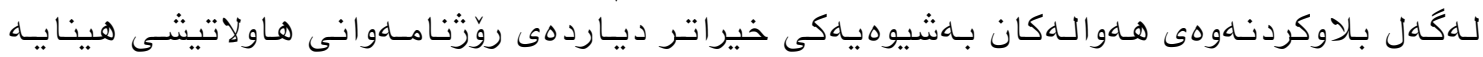

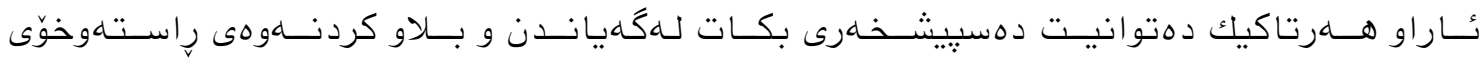

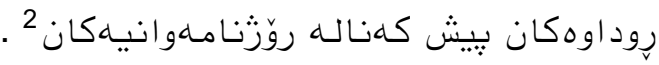

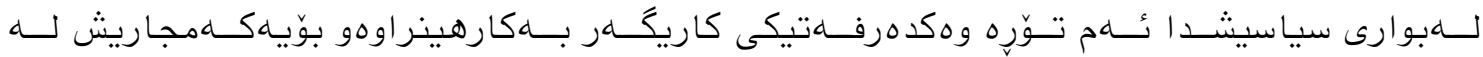

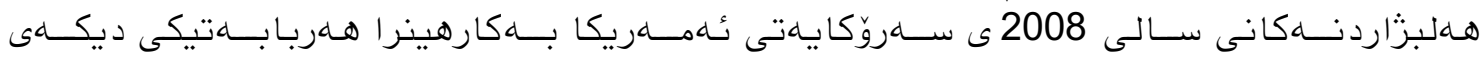

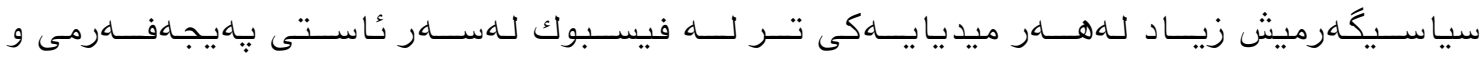

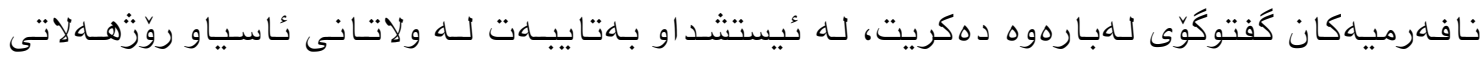

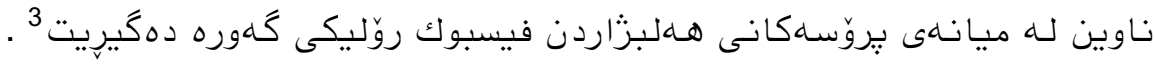

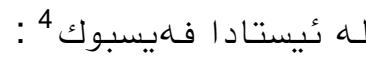

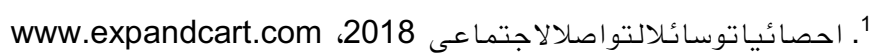

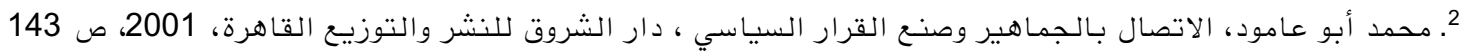

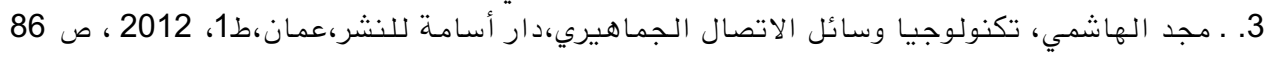
4. احصائياتوسائلالتواصلاكلاجتولونماعى 2018، 


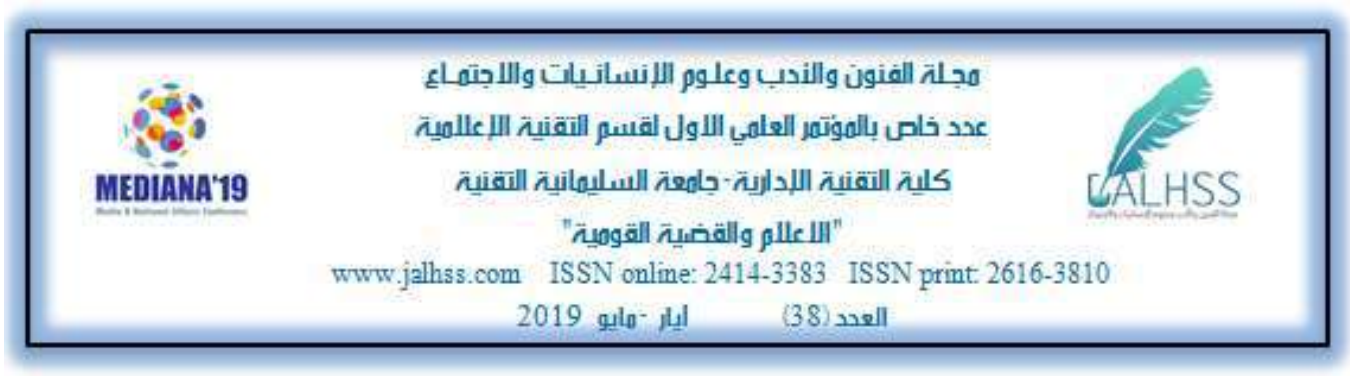

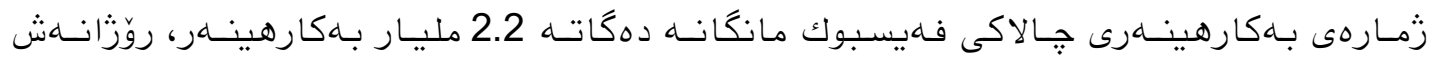

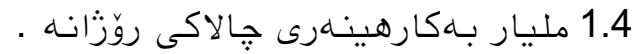

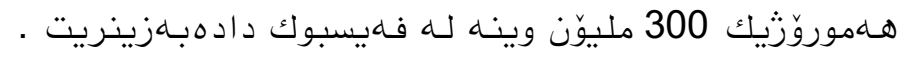

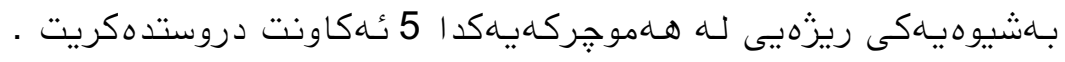

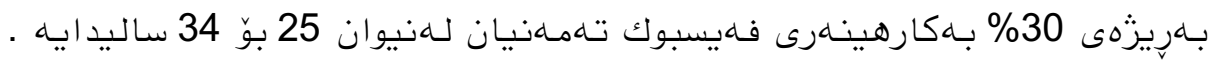

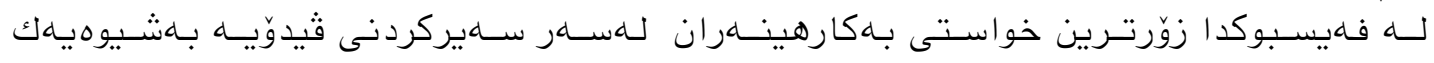

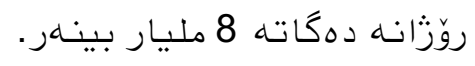

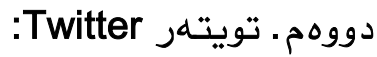

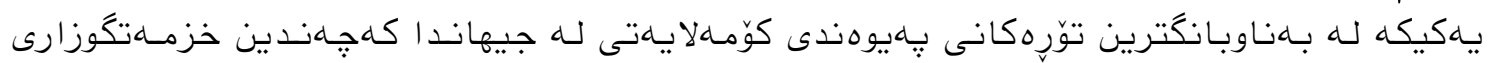

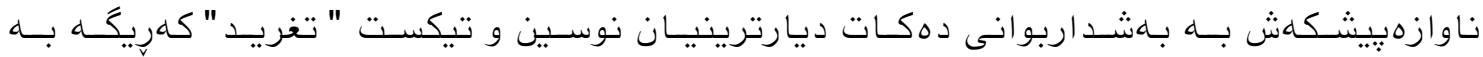

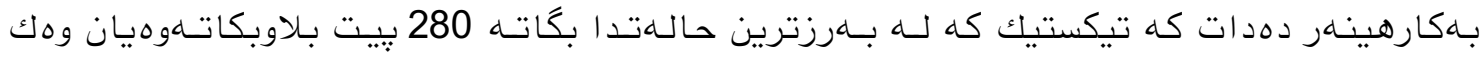

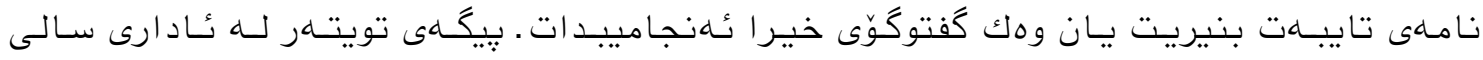

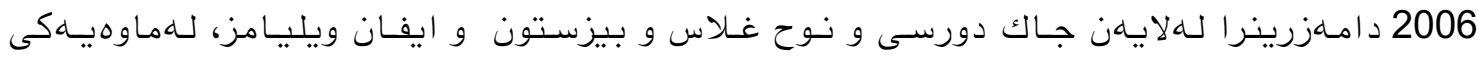

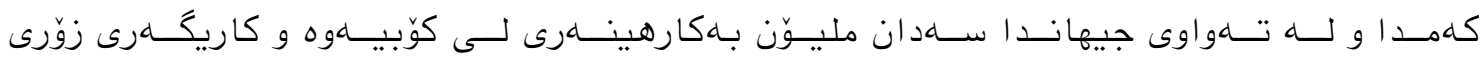

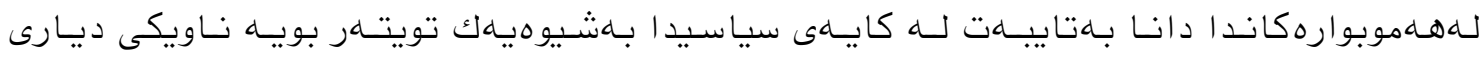

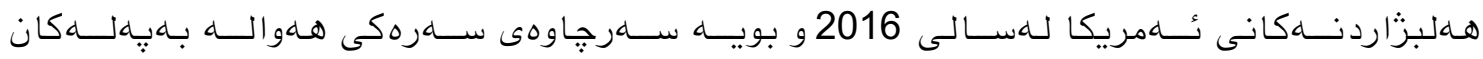

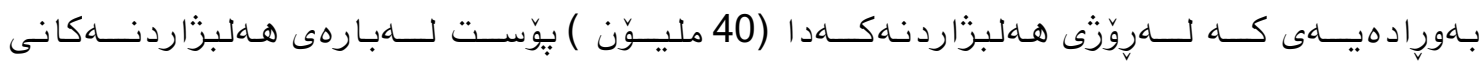

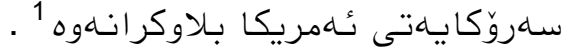

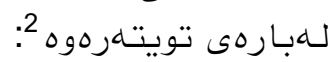

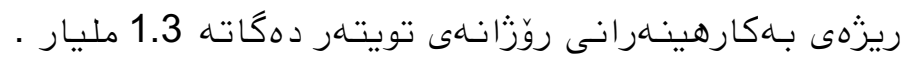

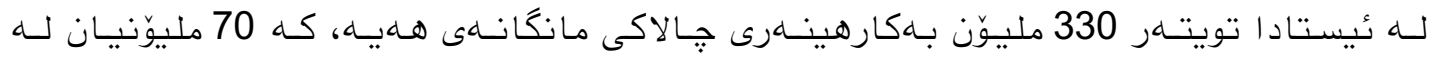

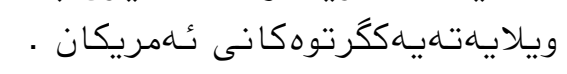

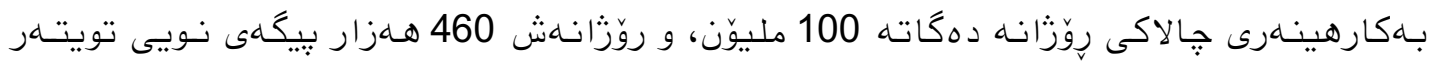

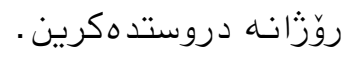

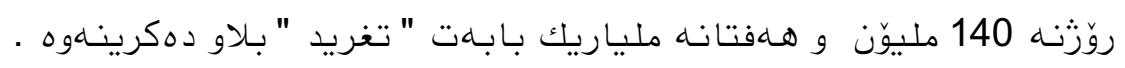

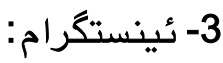

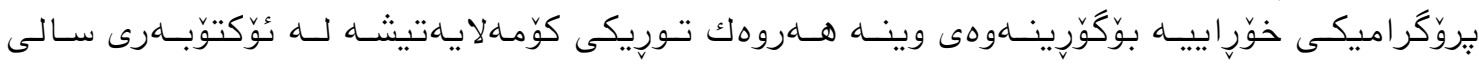

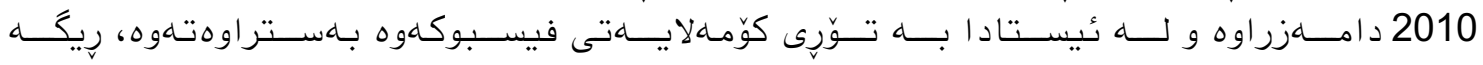




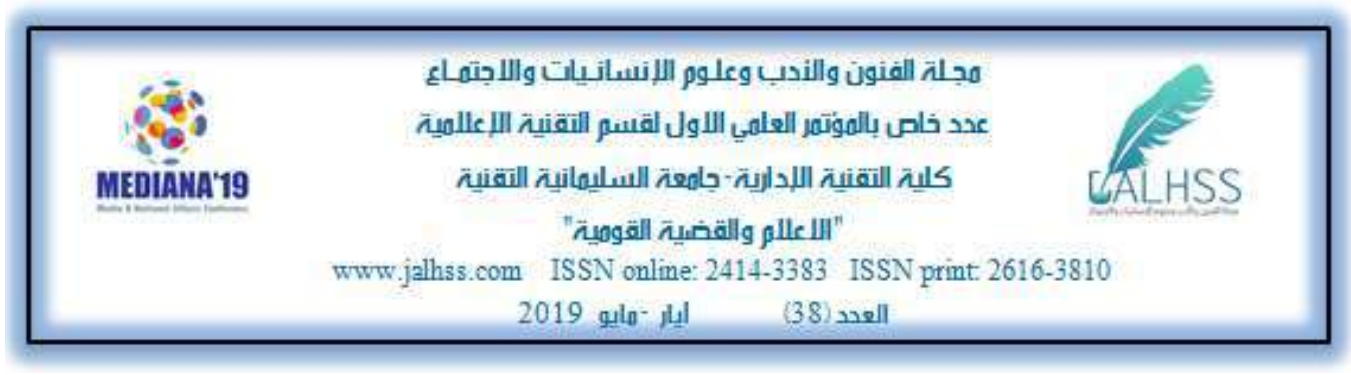

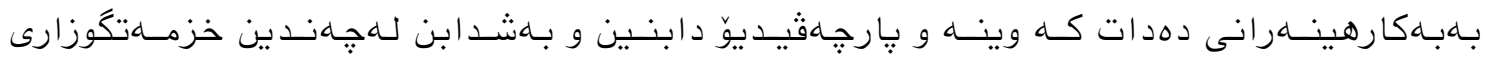

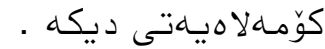

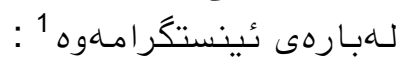

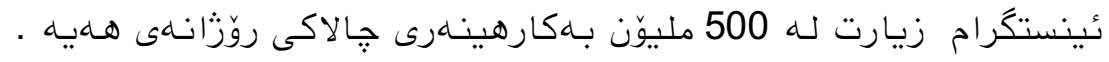

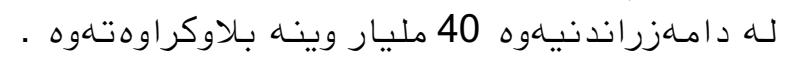

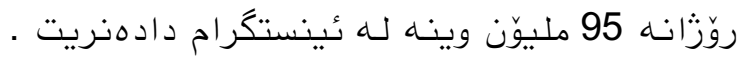

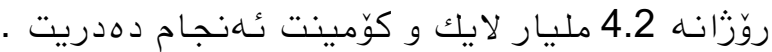

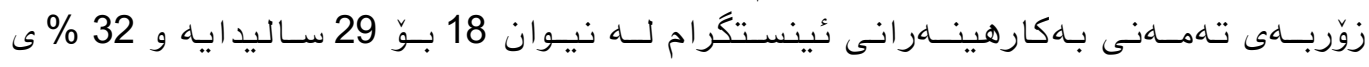

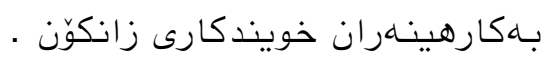

$$
\text { 4- بوتيوب: }
$$

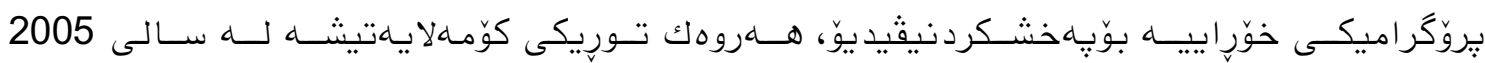

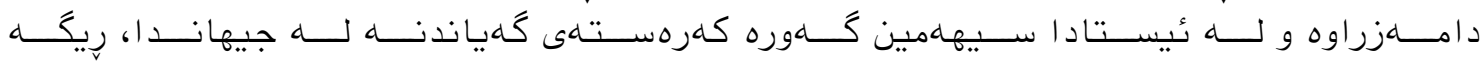

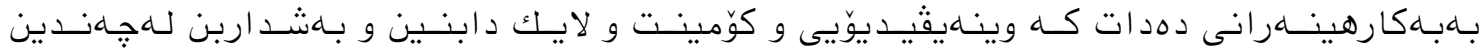

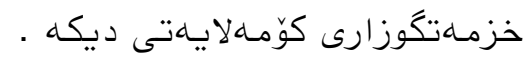

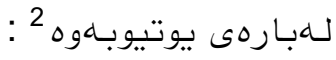

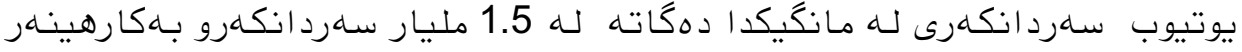

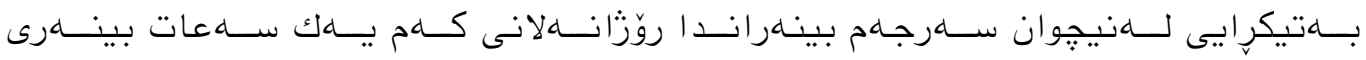

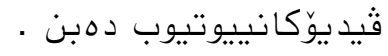

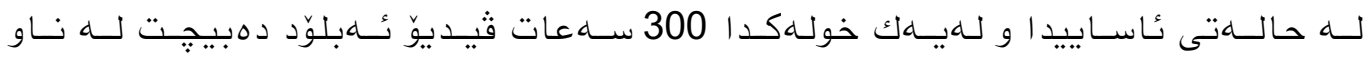
يوتيوبدا

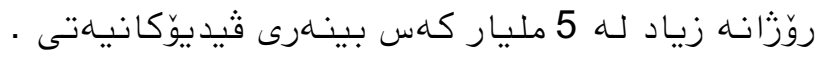

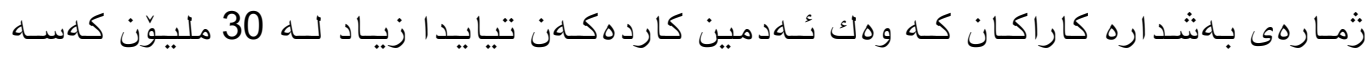

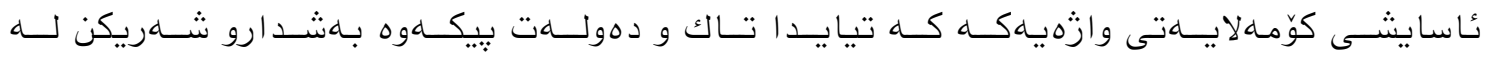

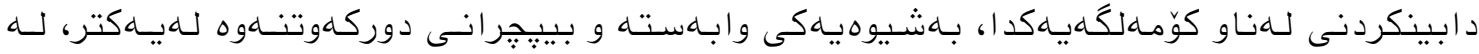

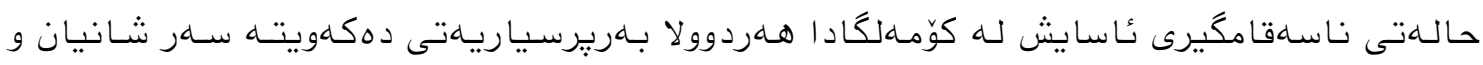

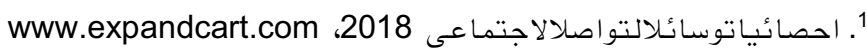

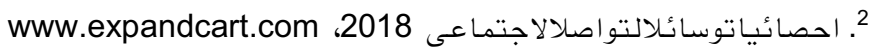




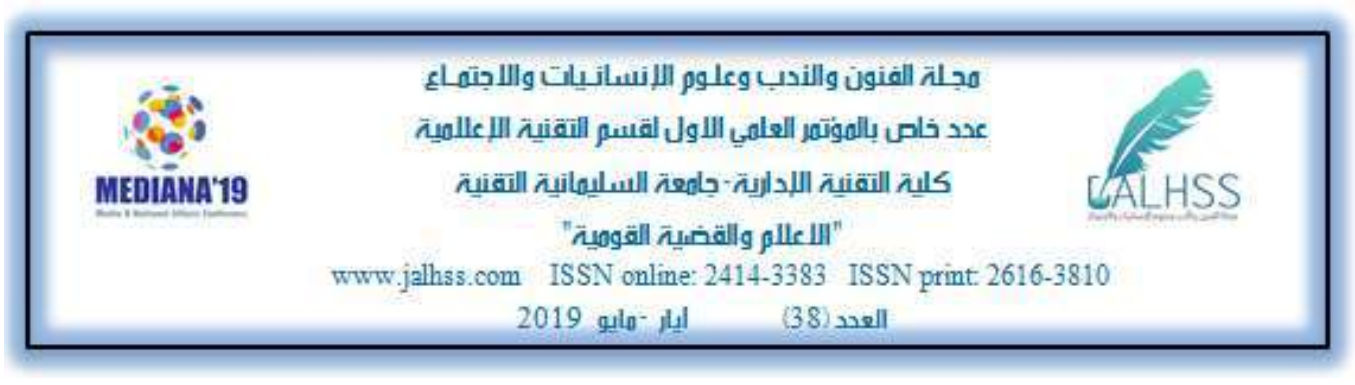

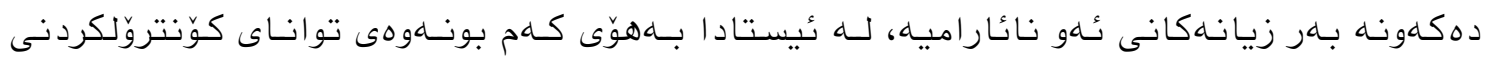

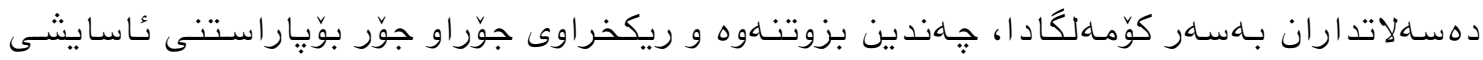

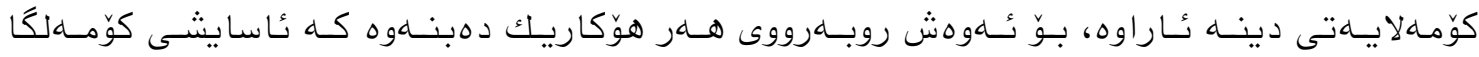

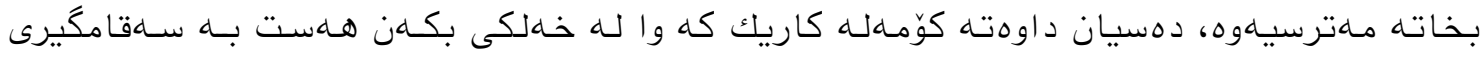

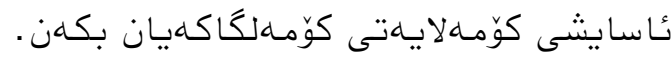

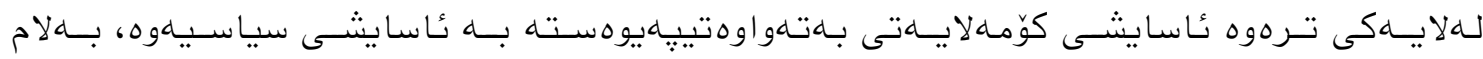

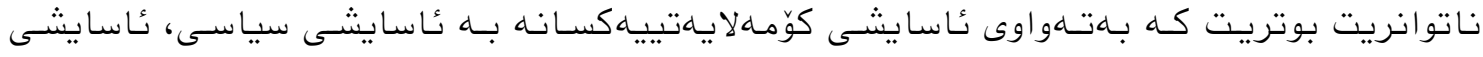

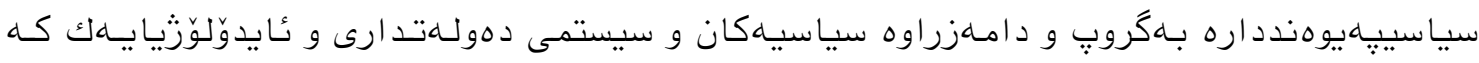

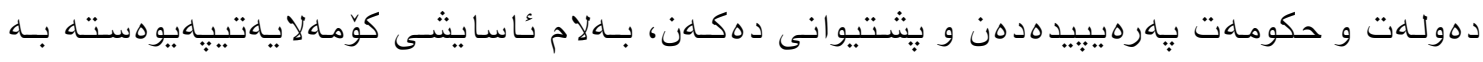

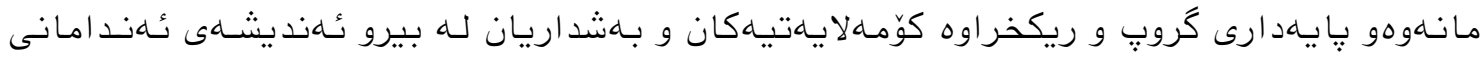

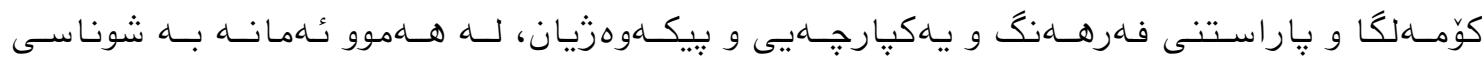

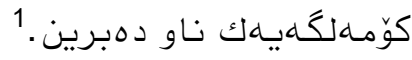

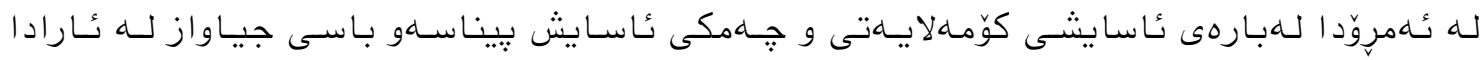

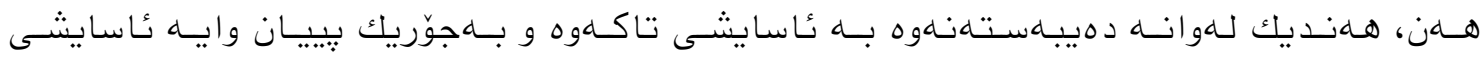

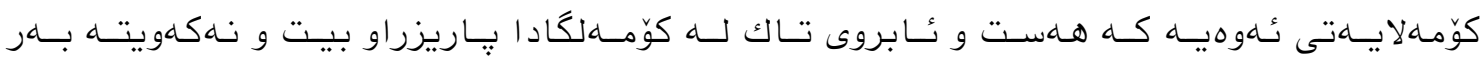

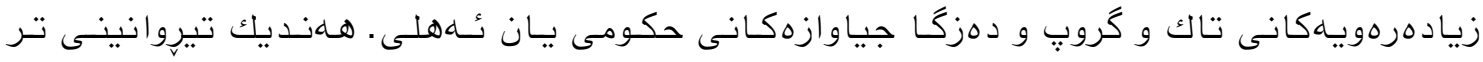

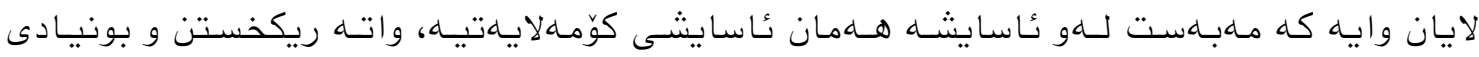

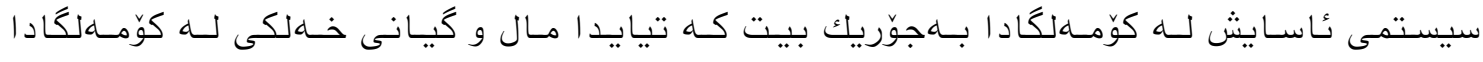

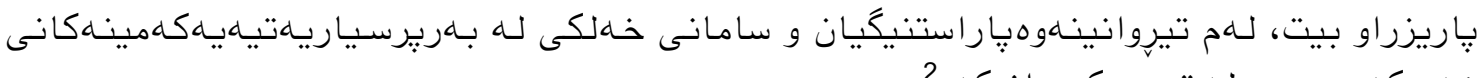

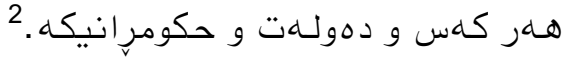

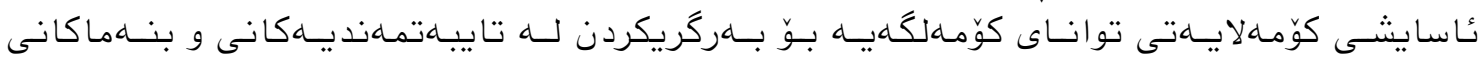

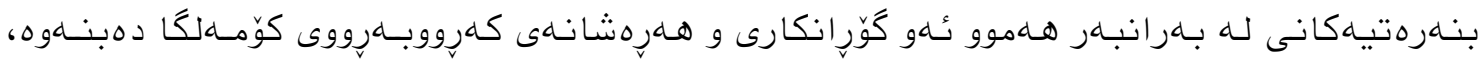

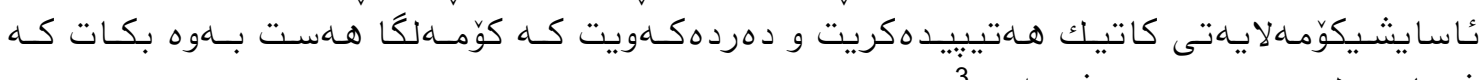

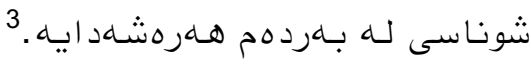

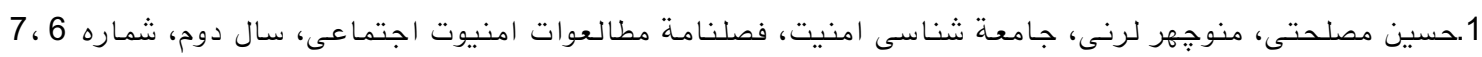

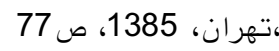
2. منوجهر لرنى، 1385، صَّيب شناسى امنيت، تهران: نشر قِيام، 1383، ص 13 3. محسن نيازى و الهام شفايى مقدم و ياسمن شادفر. بررسى رابطه بين ميزان سرمايه اجتماعى و احساس امنيت

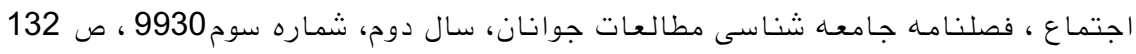




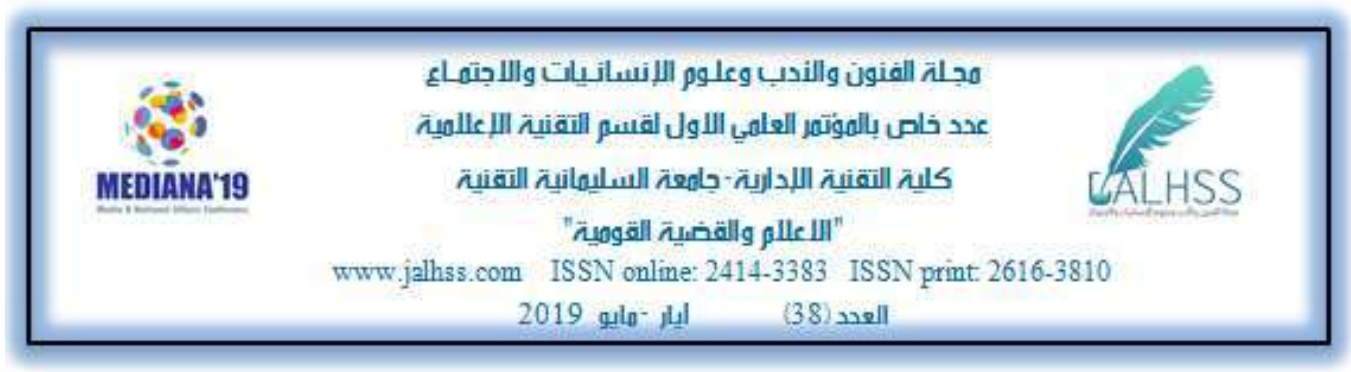

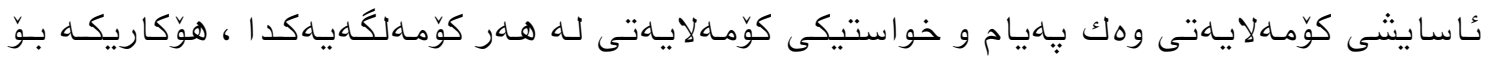

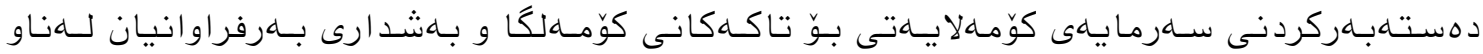

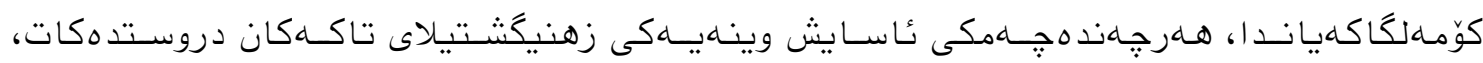

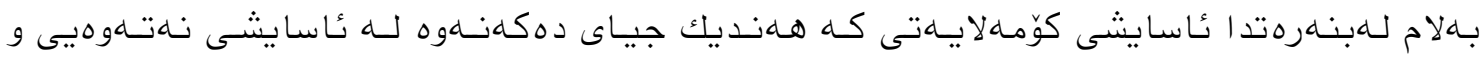

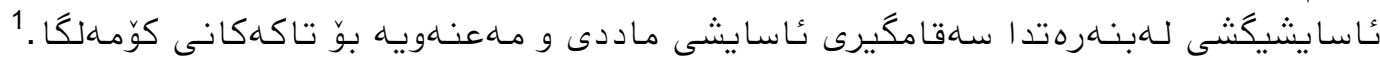

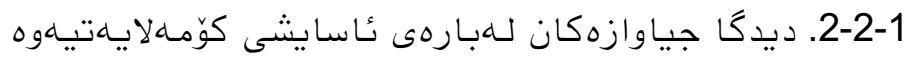

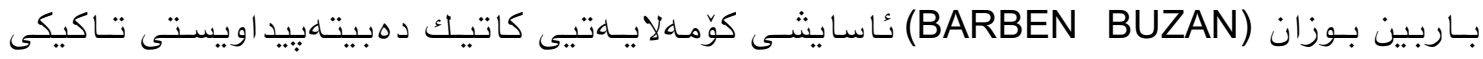

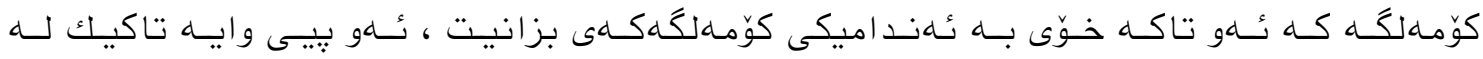

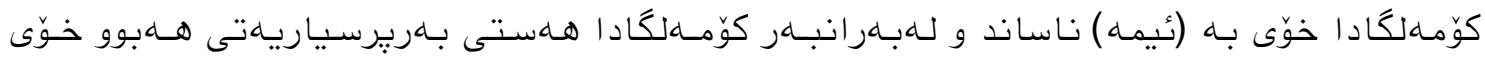

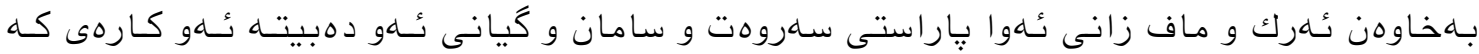

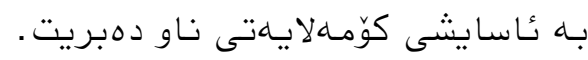

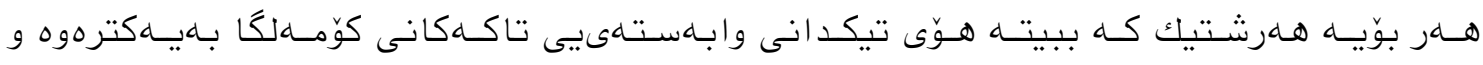

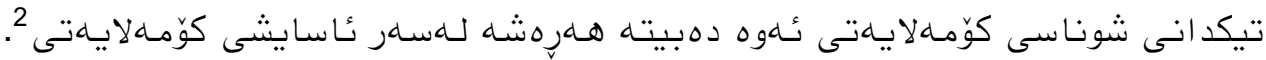

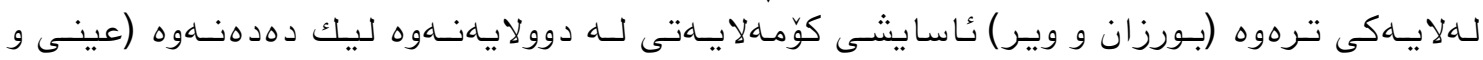

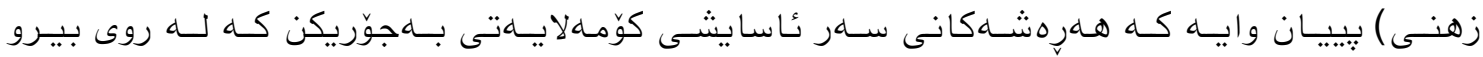

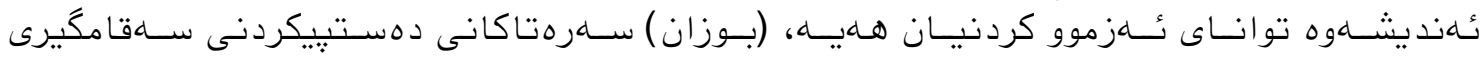

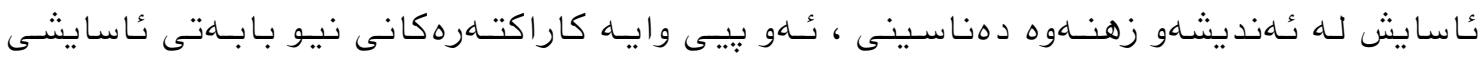

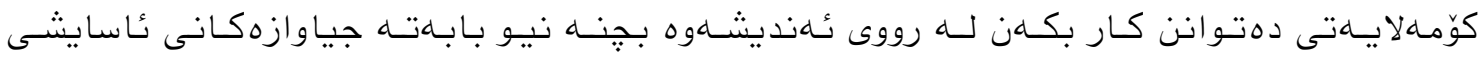

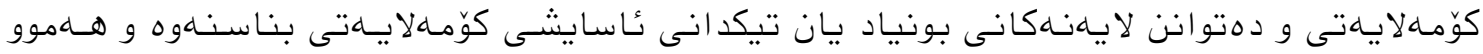

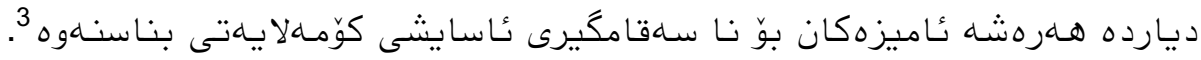

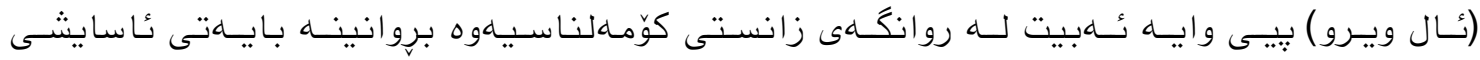

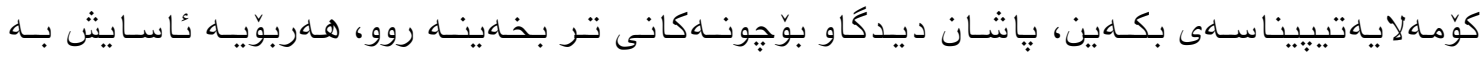

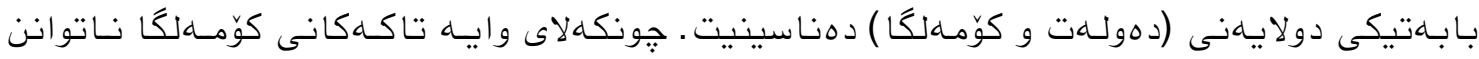

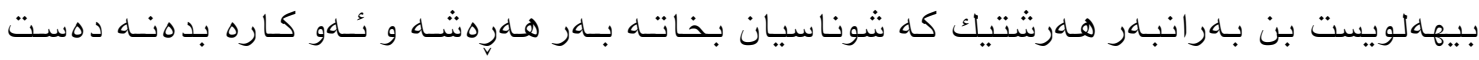

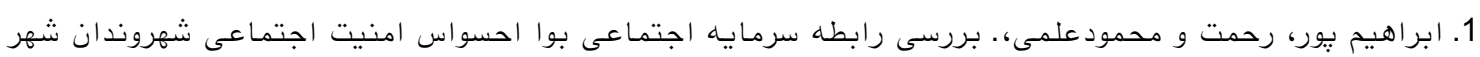

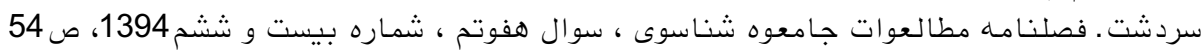

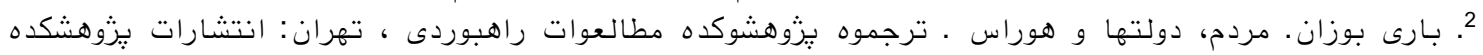
مطالعات راهبردى. 1378، لـ بوران 3

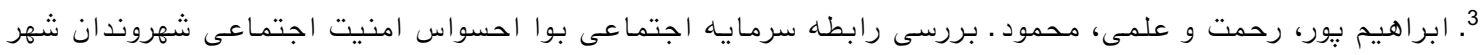

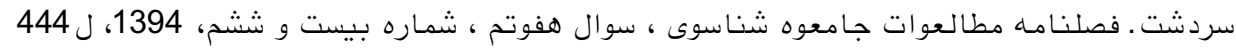

DOI: $10.33193 /$ JALHSS.38.5 


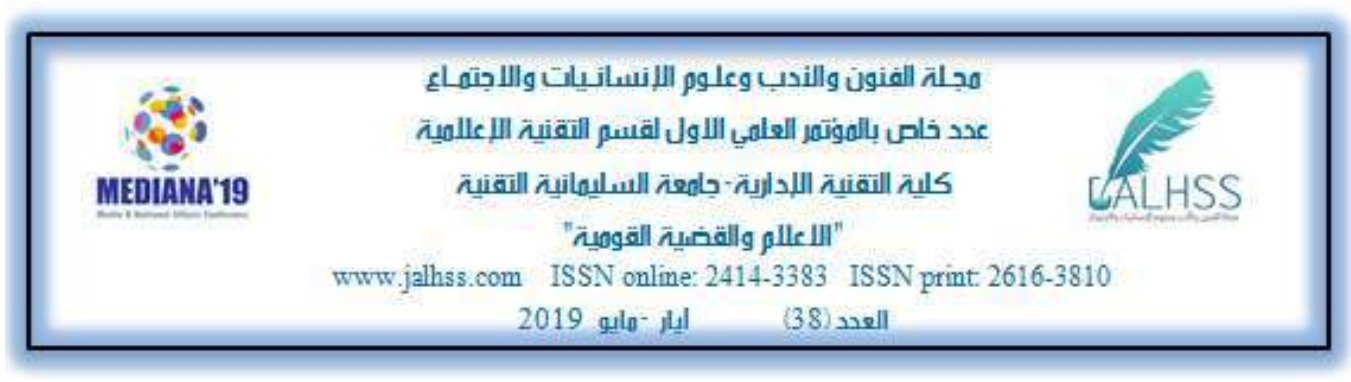

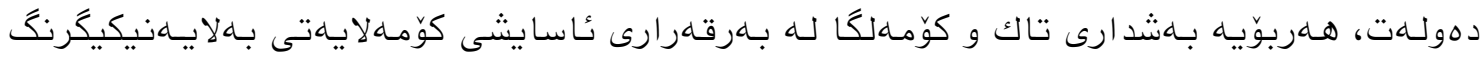

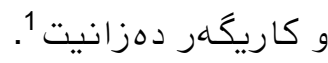

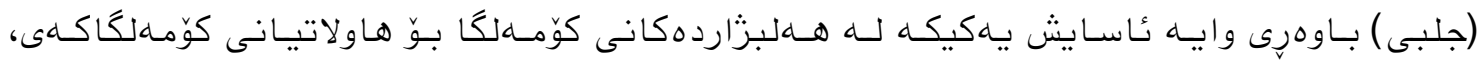

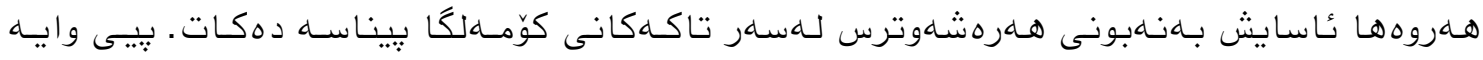

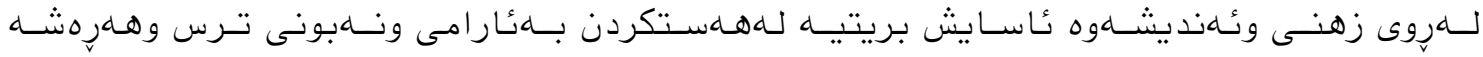

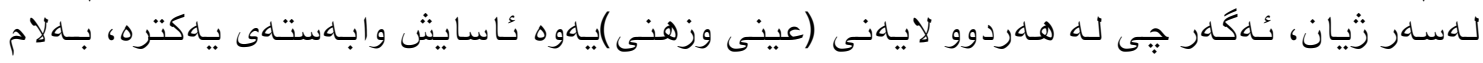

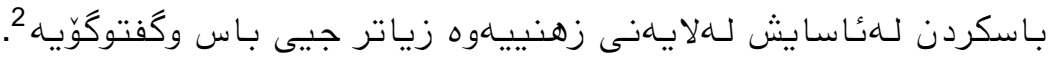

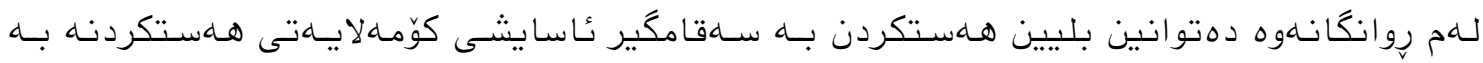

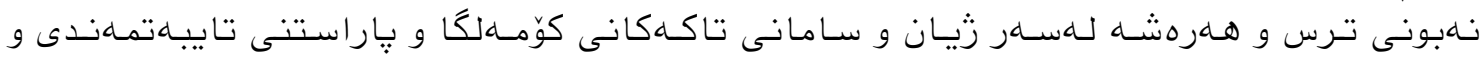

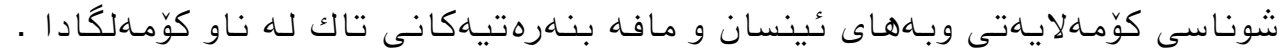

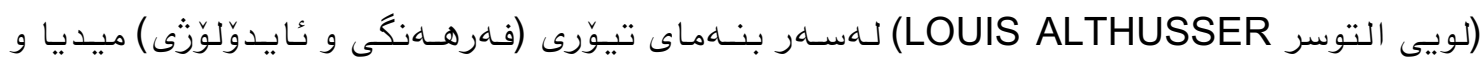

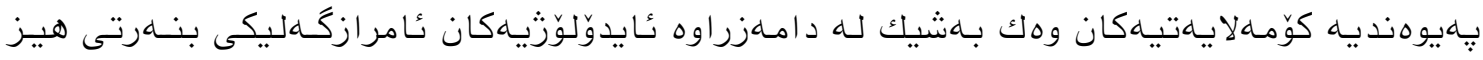

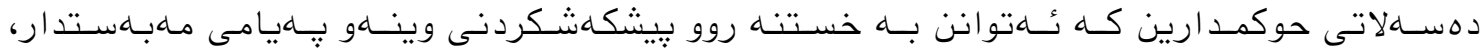

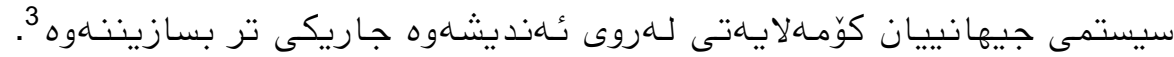

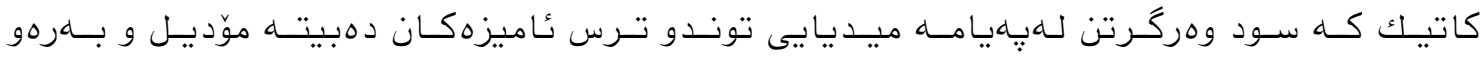

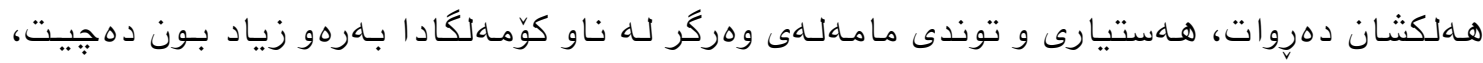

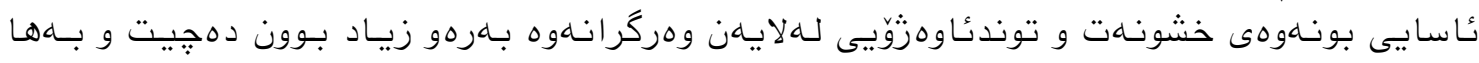

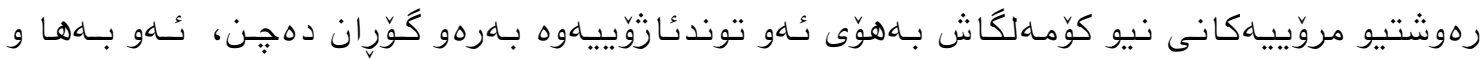

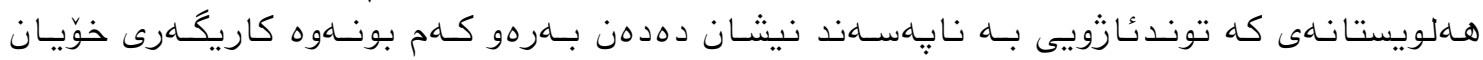

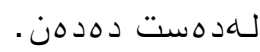

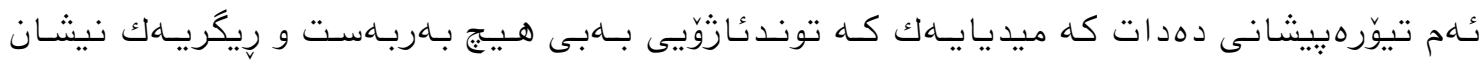

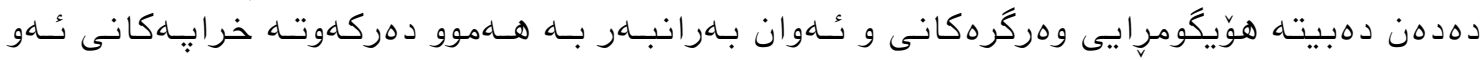

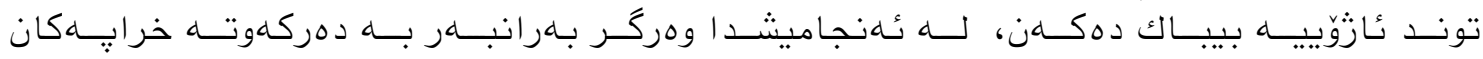

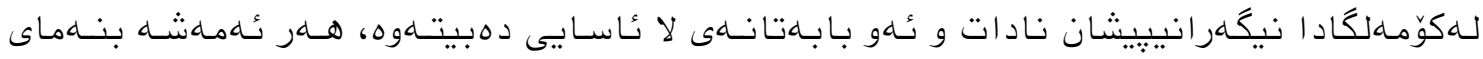

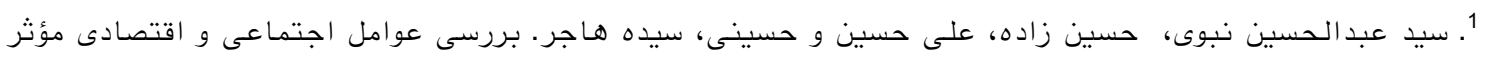

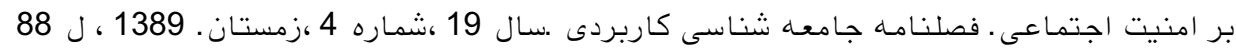

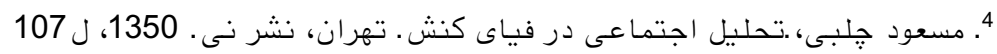

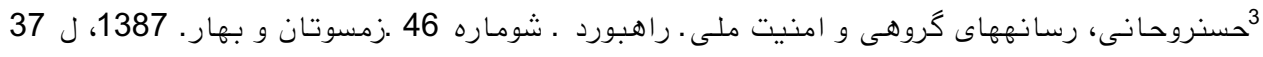




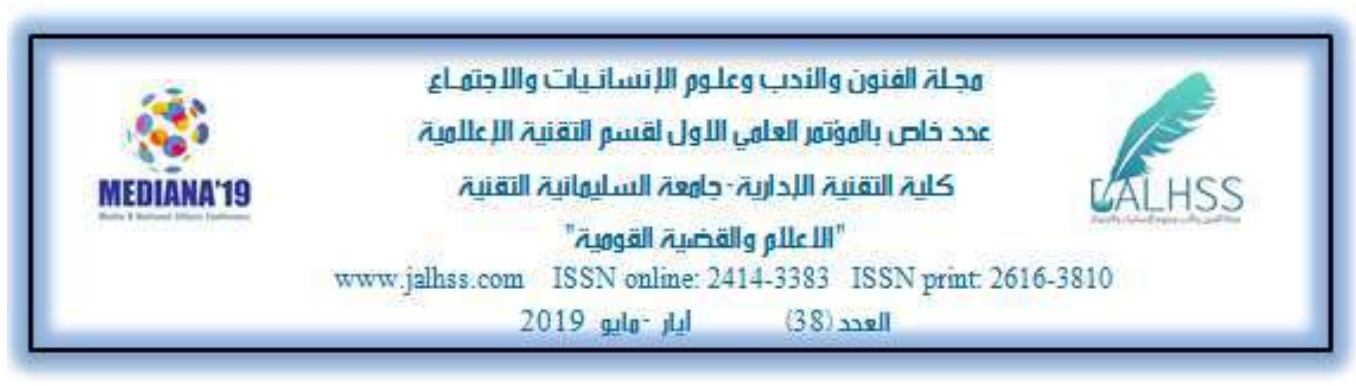

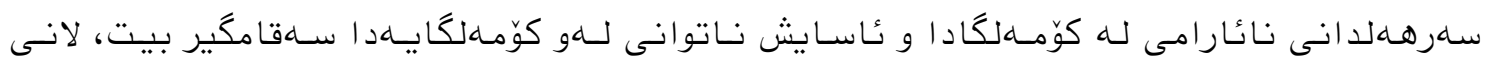

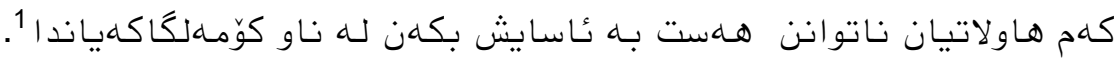

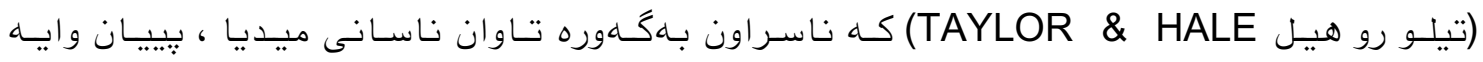

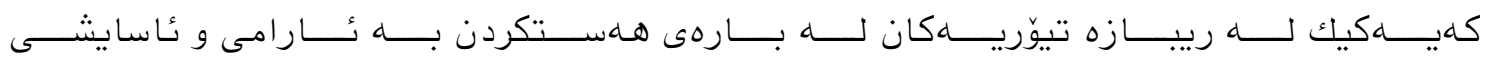

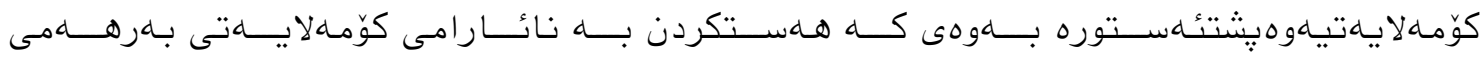

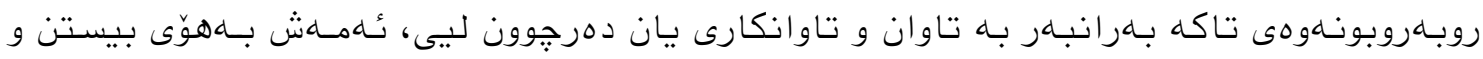

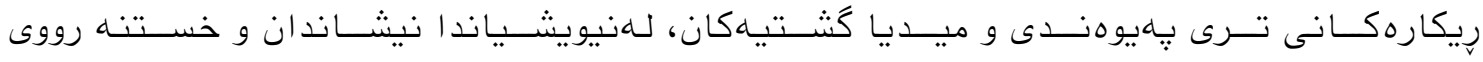

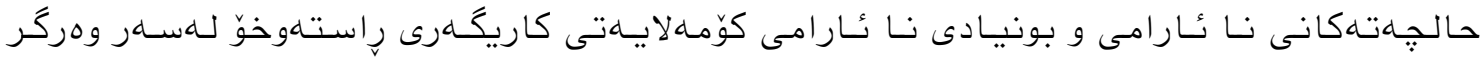

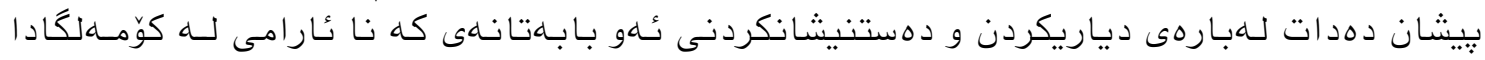

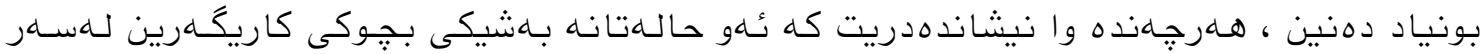

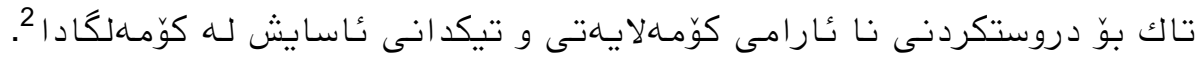

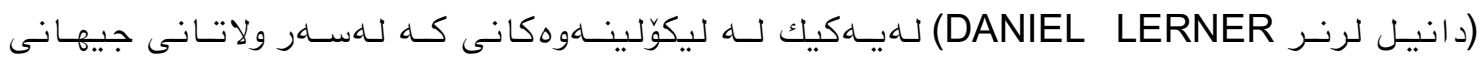

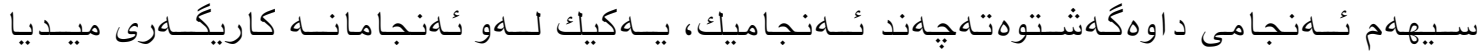

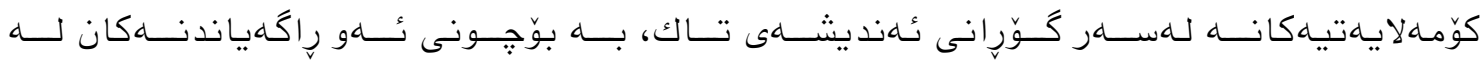

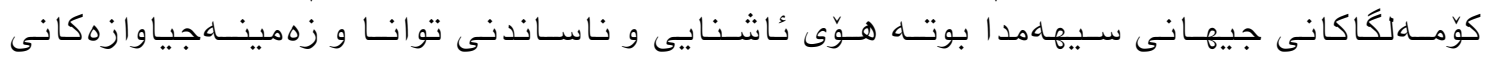

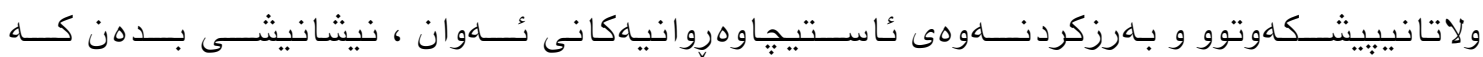

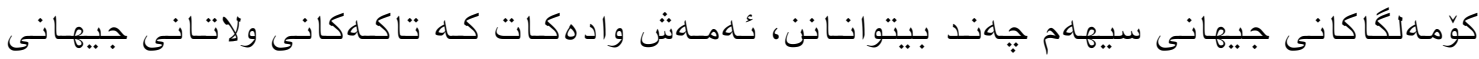

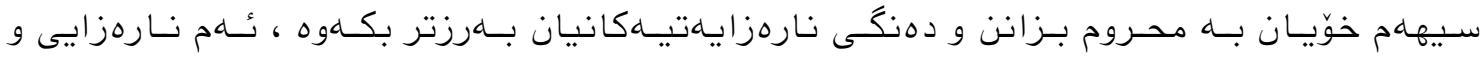

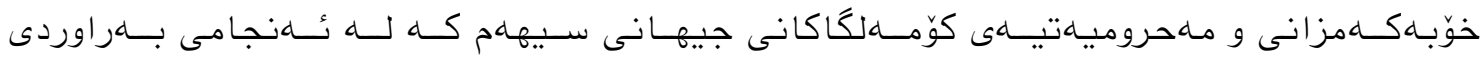

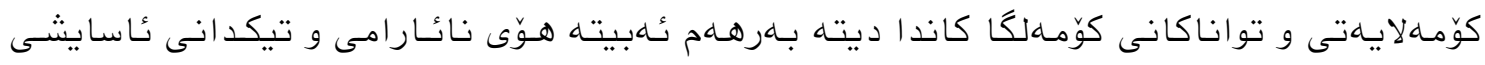
كوّمهالايسهتى 3

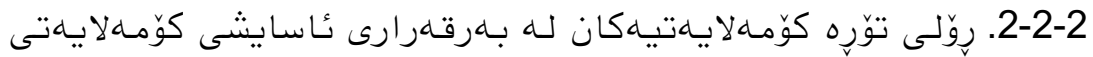

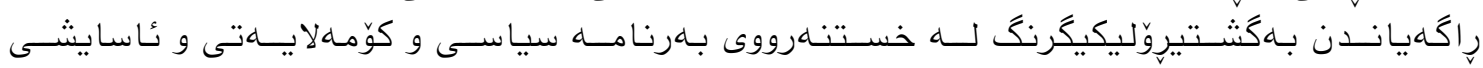

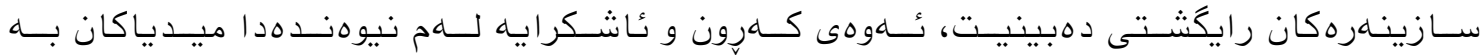

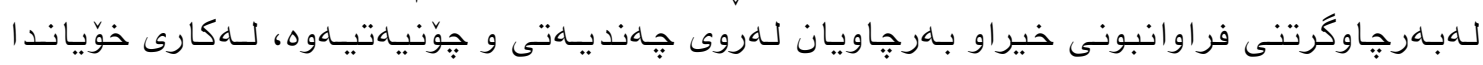

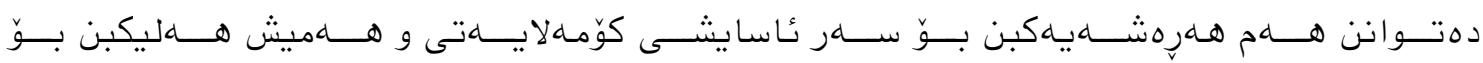

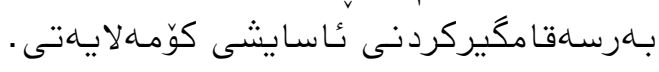

1. جليل عزيزيو حيدرخانى، هابيول. اينترنوت و جوالش هواى امنيتوى . خورم آبواد : همايش ملى احساس امنيت. تابستان. 1391، ل 45

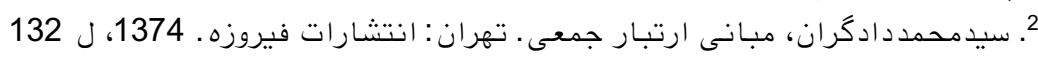

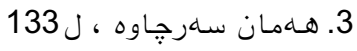




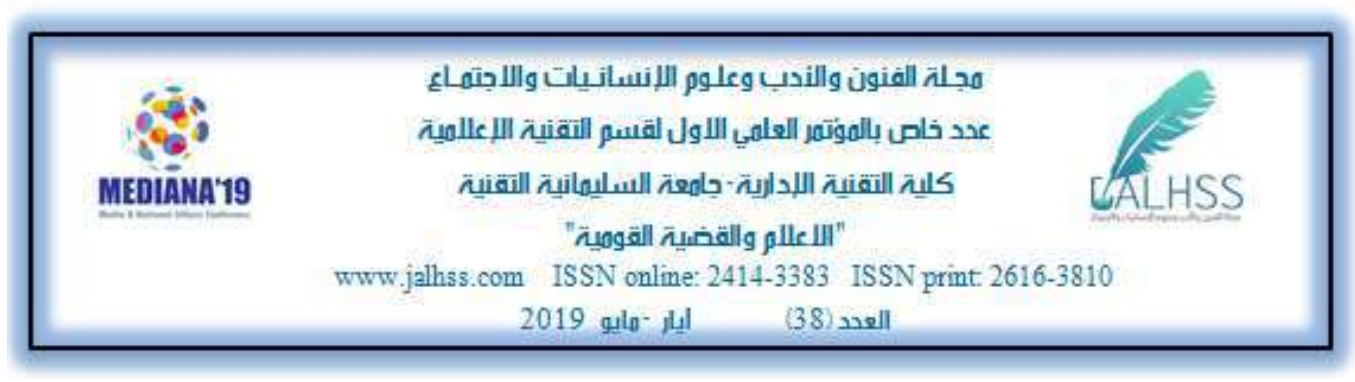

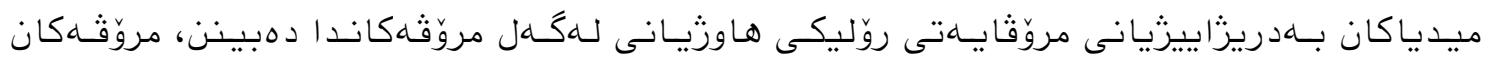

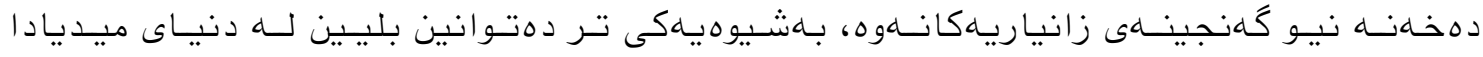

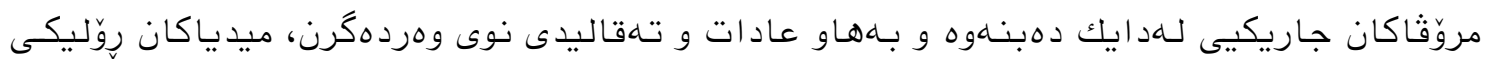

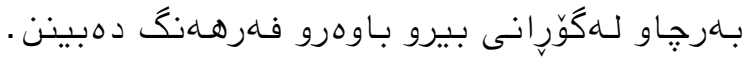

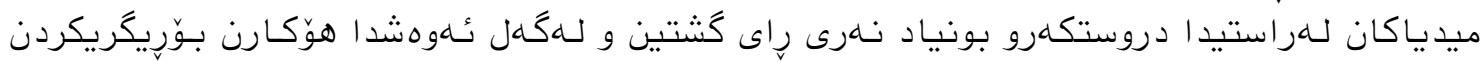

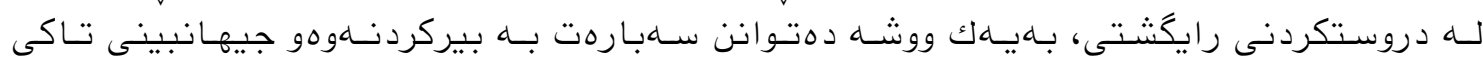

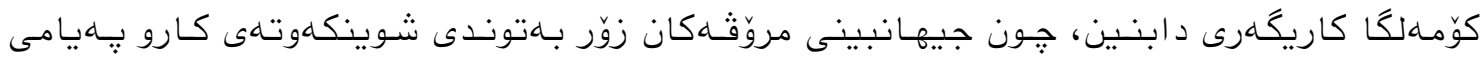

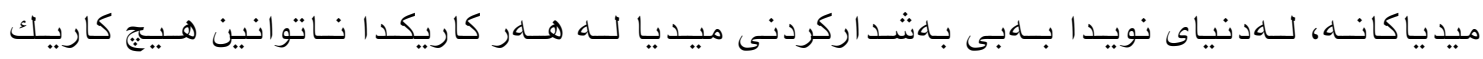

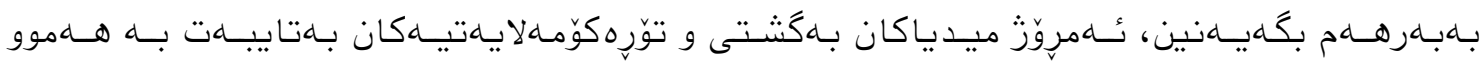

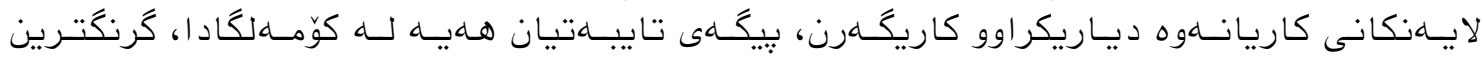

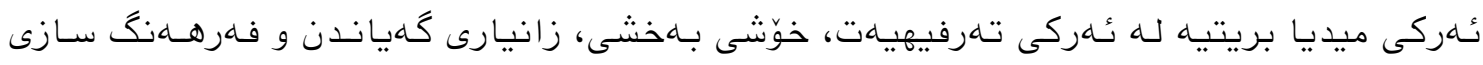

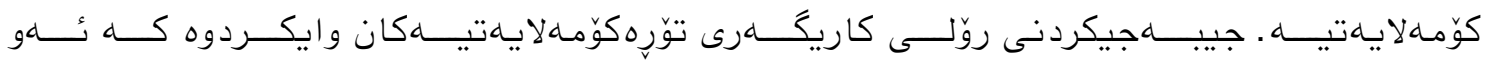

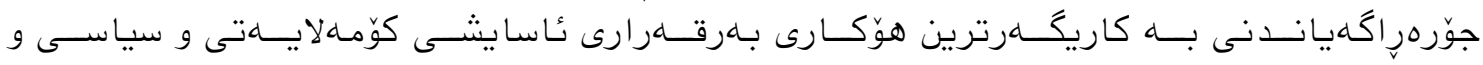

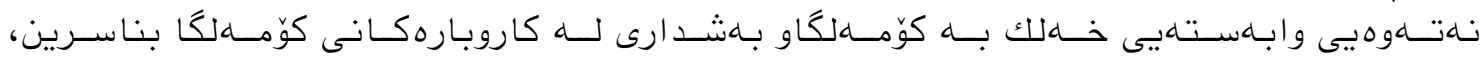

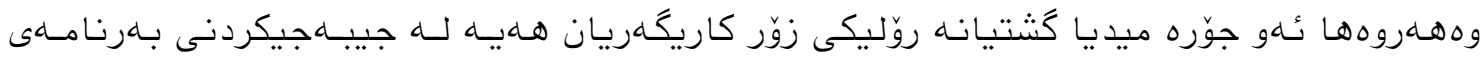

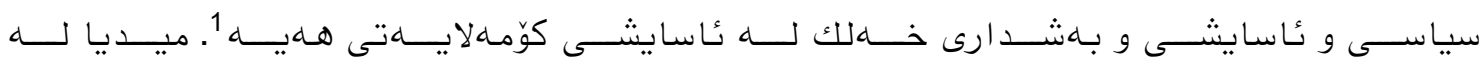

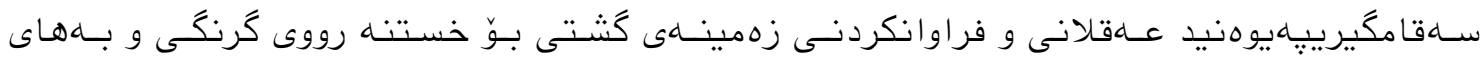

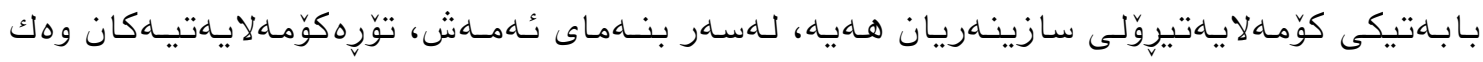

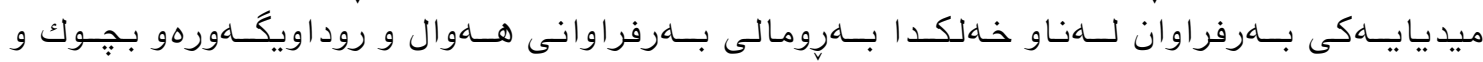

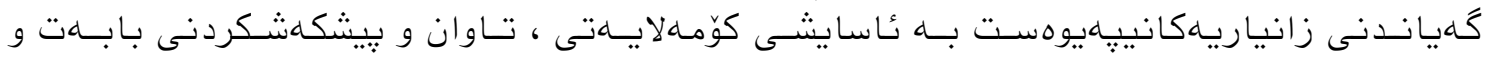

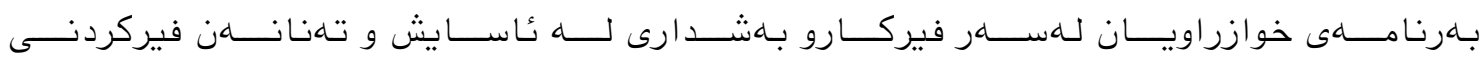

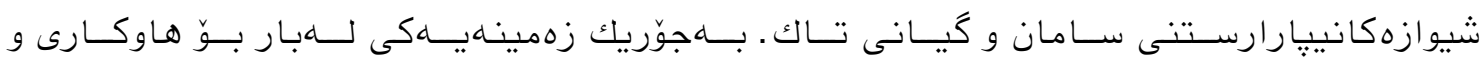

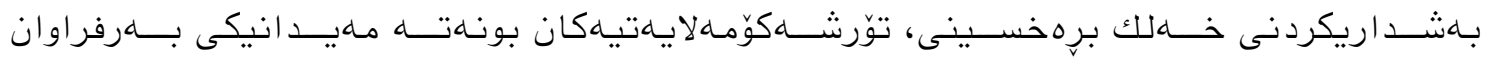

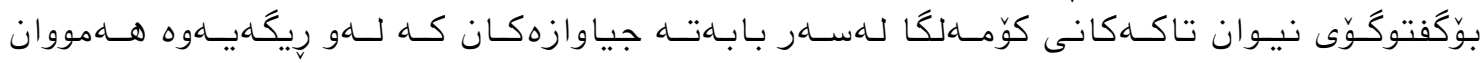

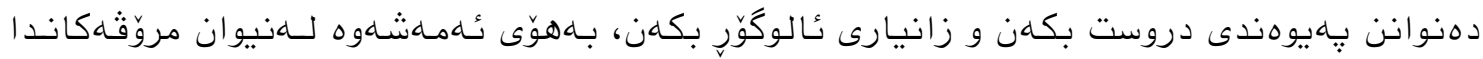

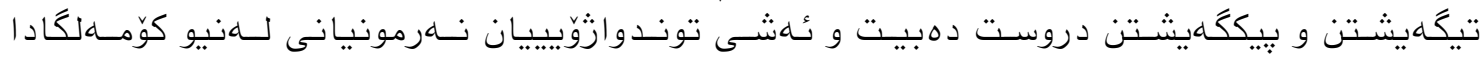

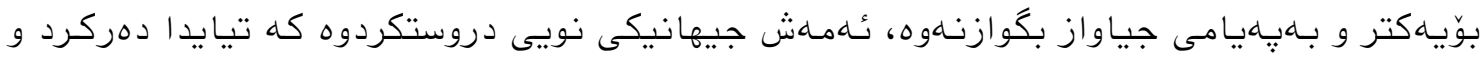

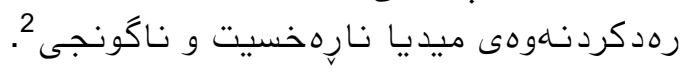

1. مصطفوى، فرحناز. نقش رسانهها در امنيت اجتماعى، فصلنامه علمى - تخصصويدانش انتظامى پِليس پايتخت، سال هشتم، شماره 9 ، 1394، لـ لـ 118

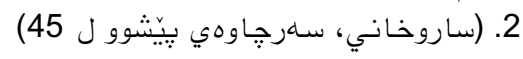




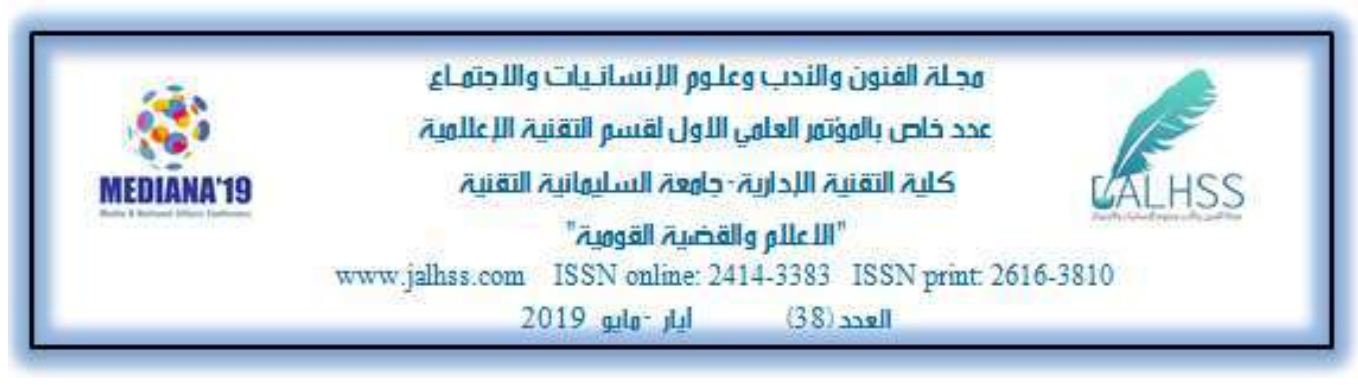

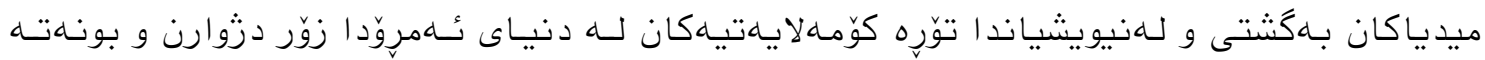

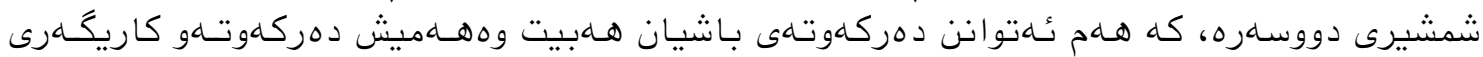

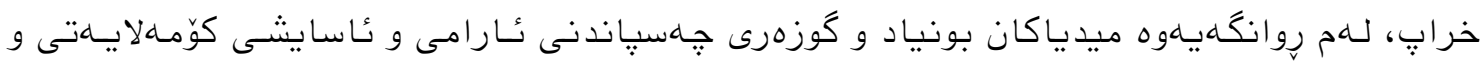

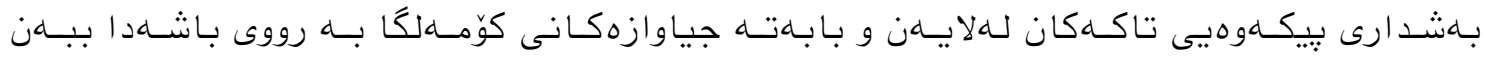

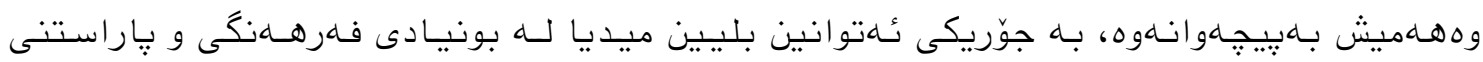

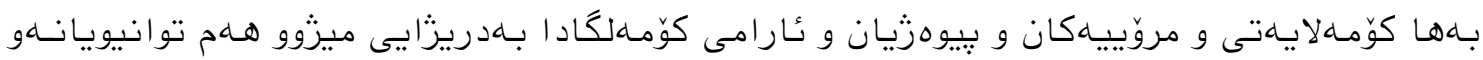

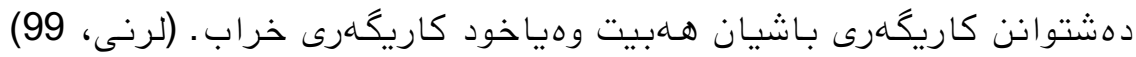

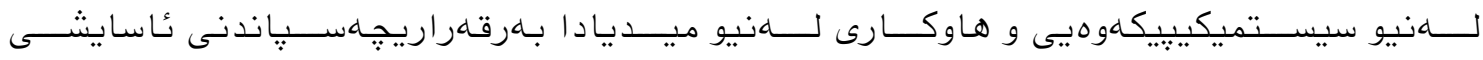

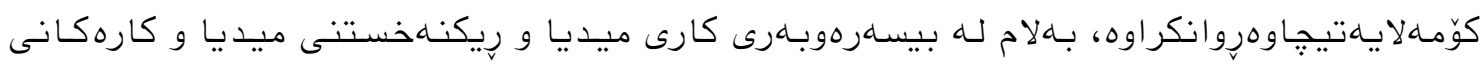

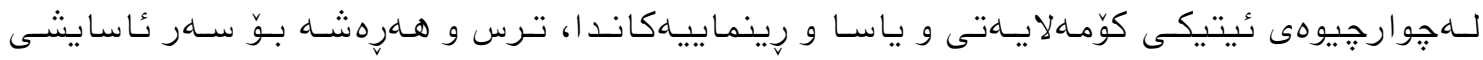

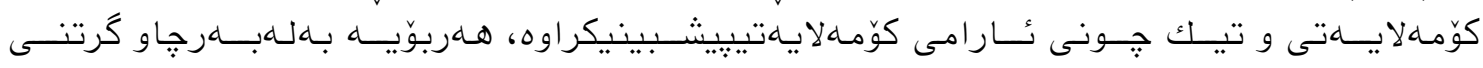

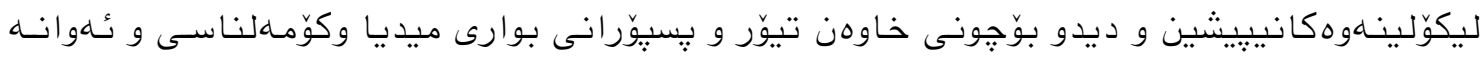

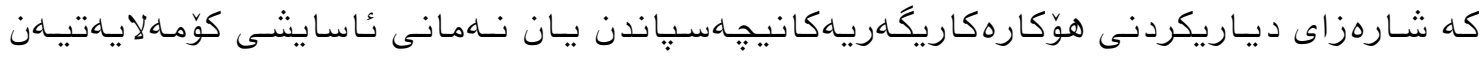

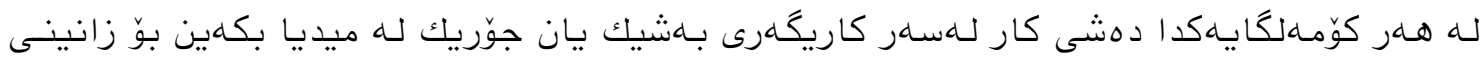

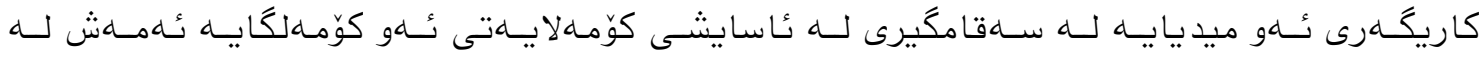

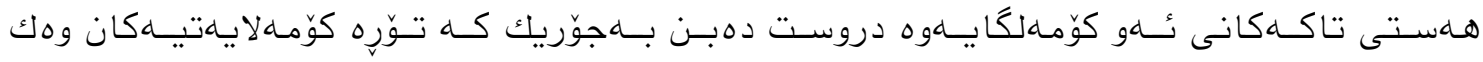

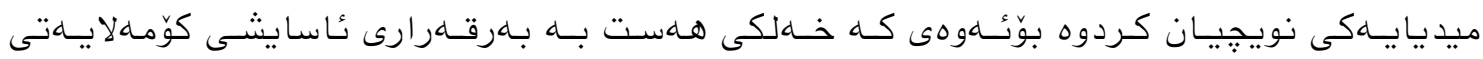

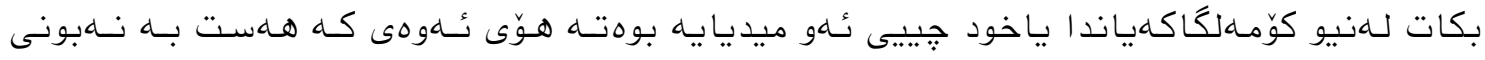

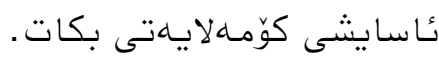

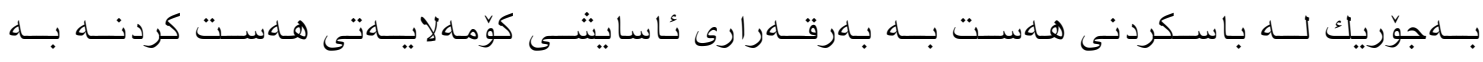

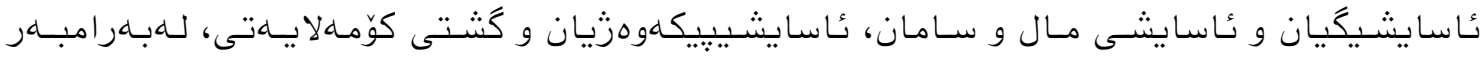

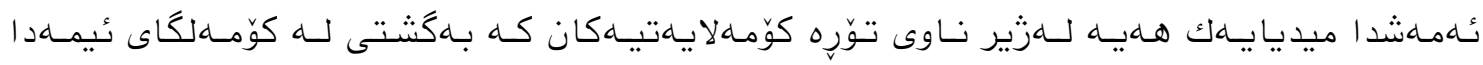

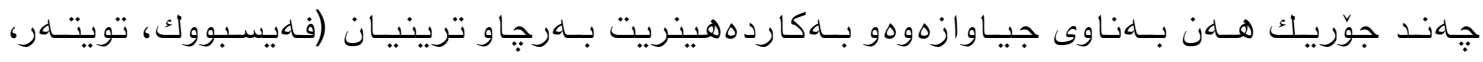
يوتيوب، ج.... 


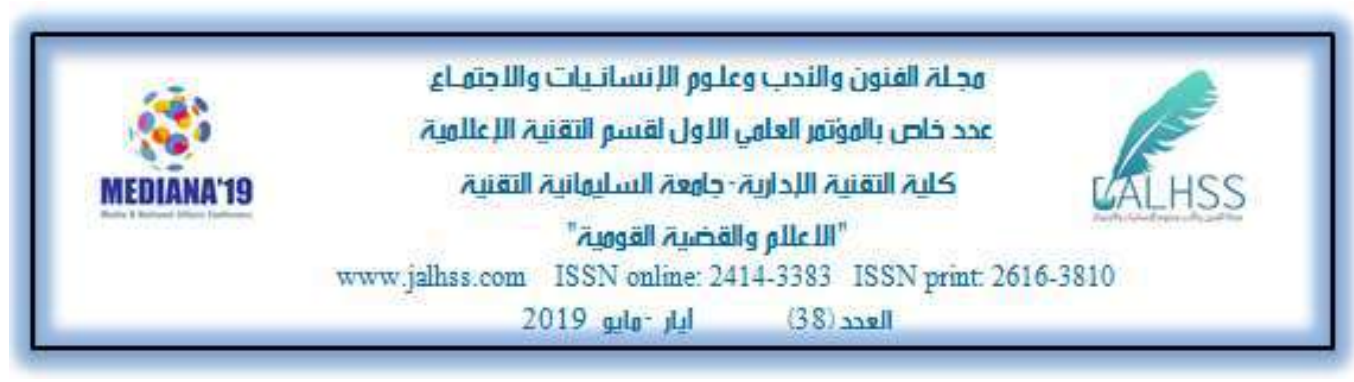

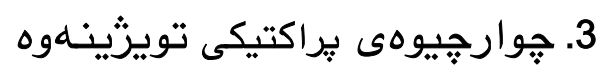

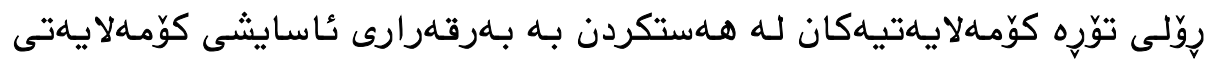

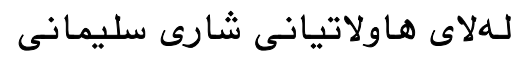

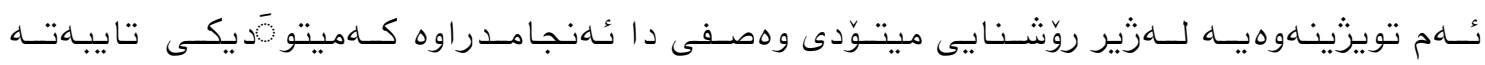

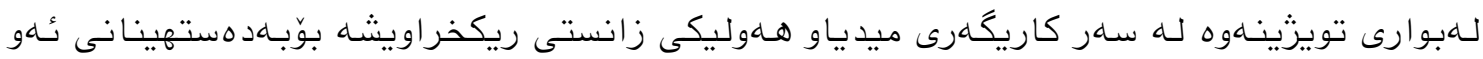

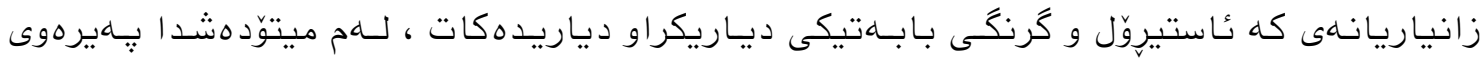
ريبازى رووبي.يوى (مسحى) كراوهان.

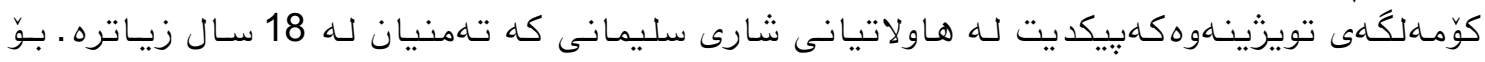

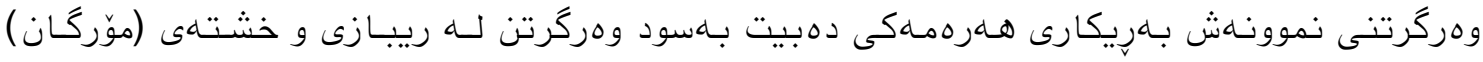

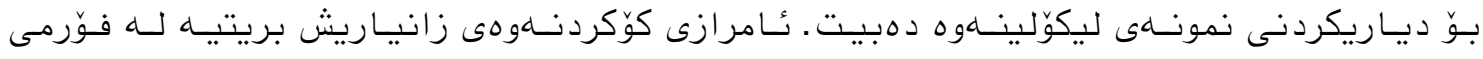

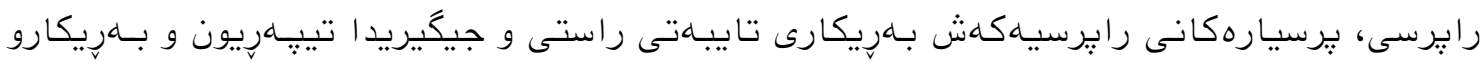

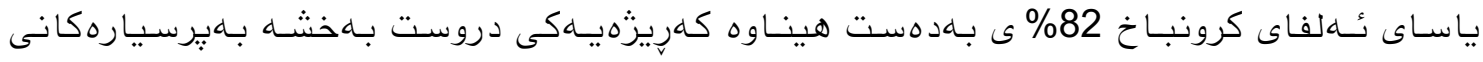

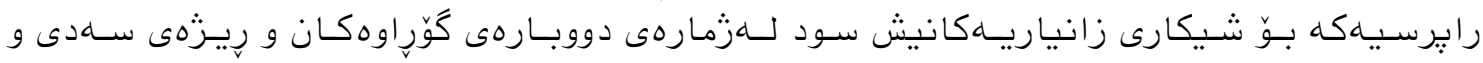

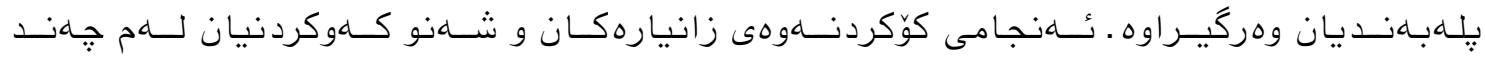

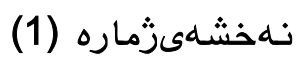

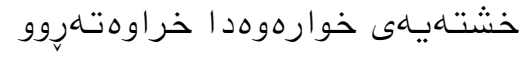

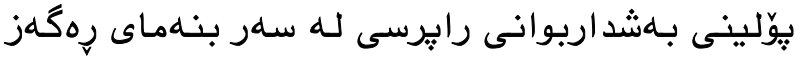

\begin{tabular}{|c|c|c|c|c|}
\hline 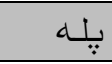 & $\%$ & دوباره & كَوْراو & j \\
\hline يهكهم & & 210 & نيّر & 1 \\
\hline دووهم & & 165 & مسيّ & 2 \\
\hline & $\% 100$ & 375 & & كوّ \\
\hline
\end{tabular}

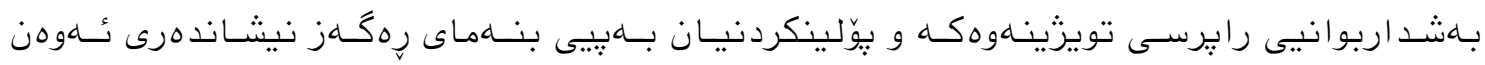

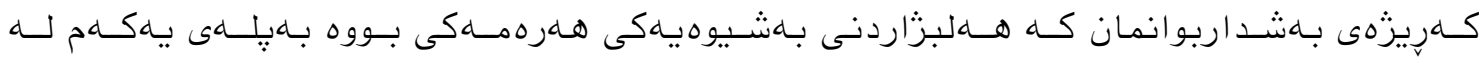

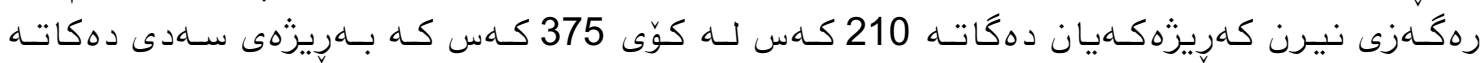

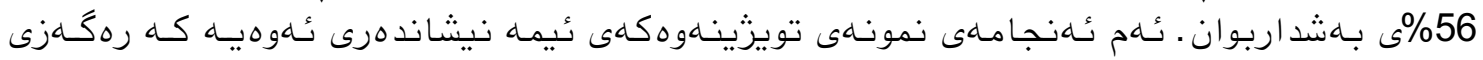




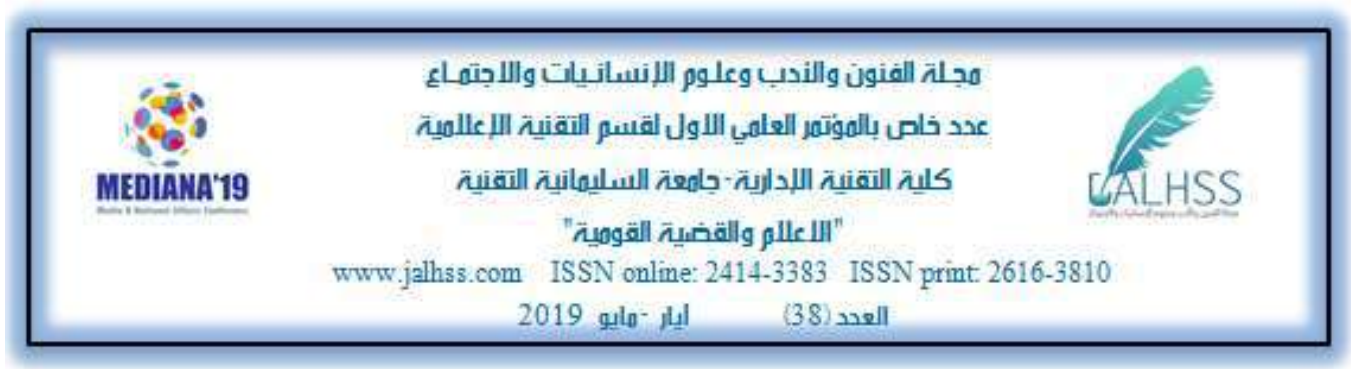

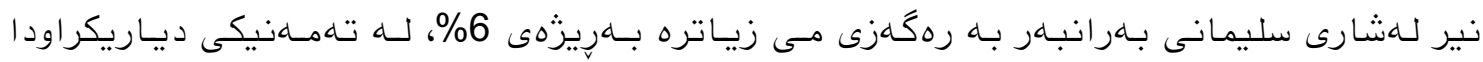

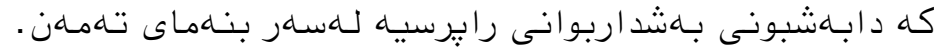

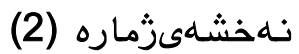

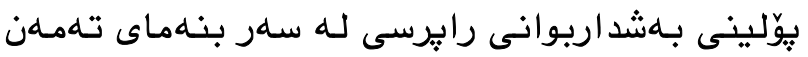

\begin{tabular}{|c|c|c|c|c|}
\hline باله & $\%$ & دوباره & كُوْراو & j \\
\hline جوارهم & $\% 17.4$ & 65 & $22-18$ & 1 \\
\hline يهكهم & $\% 21.8$ & 82 & $27-23$ & 2 \\
\hline س.يههام & $\% 19.3$ & 72 & $32-28$ & 3 \\
\hline يِينجهم & $\% 11.3$ & 43 & $37-33$ & 4 \\
\hline دووهم & $\% 21.6$ & 81 & $42-38$ & 5 \\
\hline \multirow[t]{2}{*}{ شـهـام } & $\% 8.6$ & 32 & 43 - زياتر & 6 \\
\hline & $\% 100$ & 375 & & كوّ \\
\hline
\end{tabular}

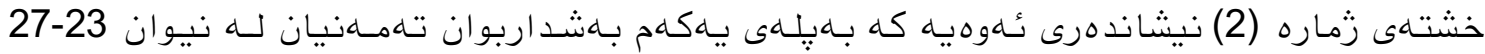

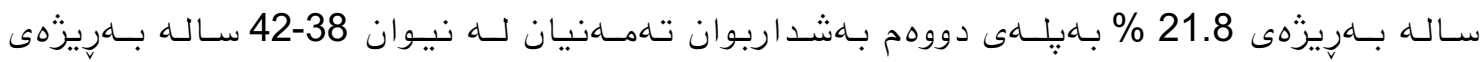

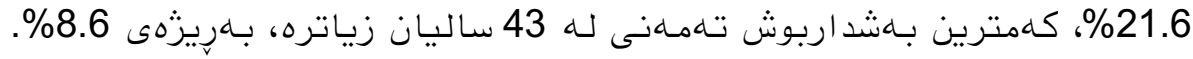

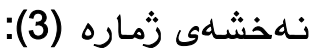

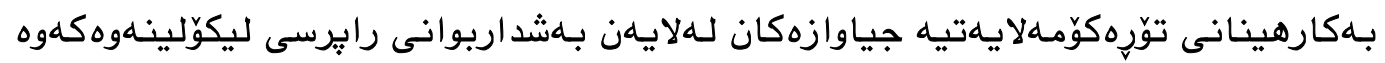

\begin{tabular}{|c|c|c|c|c|}
\hline بلـه & $\%$ & دوباره & كَوْرِ او & j \\
\hline يهكهم & \%93.3 & 350 & بهلى & 1 \\
\hline دووهم & $\% 6.7$ & 25 & نهخير & 2 \\
\hline & $\% 100$ & 375 & & كوّ \\
\hline
\end{tabular}

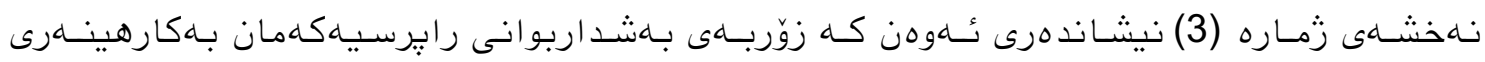

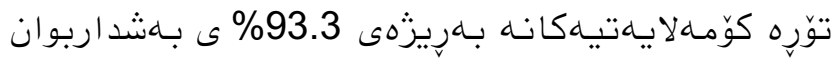




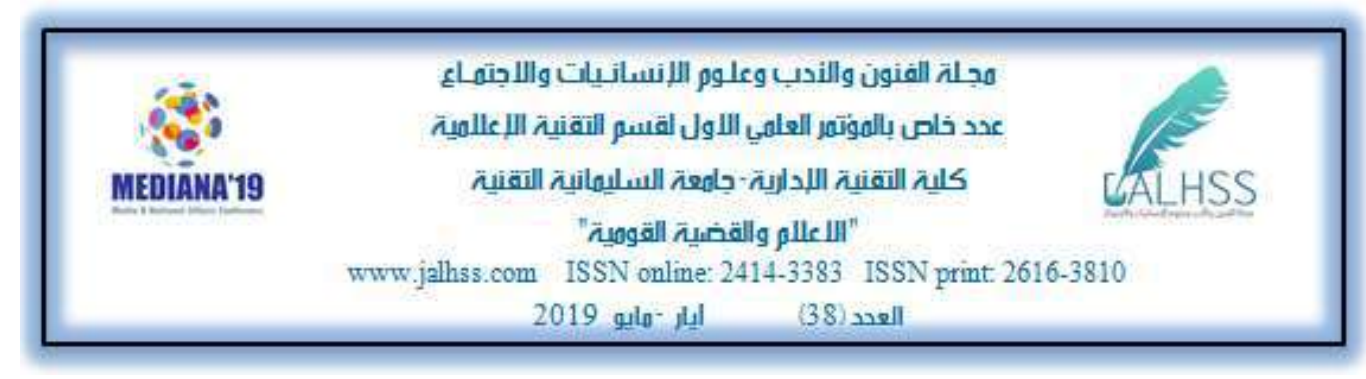

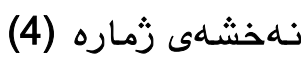

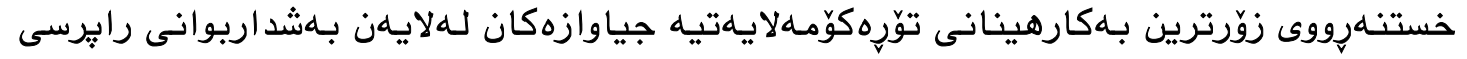

\begin{tabular}{|c|c|c|c|c|}
\hline بـ & $\%$ & دوبـاره & كَوْراو & j \\
\hline جوارهم & $\% 49.7$ & 174 & فهيسبووك & 1 \\
\hline يهكهم & $\% 6.3$ & 22 & تويتهر & 2 \\
\hline سيهـالم & $\% 14.8$ & 52 & يوتيوب & 3 \\
\hline بينجبهم & $\% 22$ & 77 & ئينستاكرام & 4 \\
\hline \multirow[t]{2}{*}{ دووهم } & $\% 7.2$ & 25 & تليگرام & 5 \\
\hline & $\% 100$ & 350 & & كوّ \\
\hline
\end{tabular}

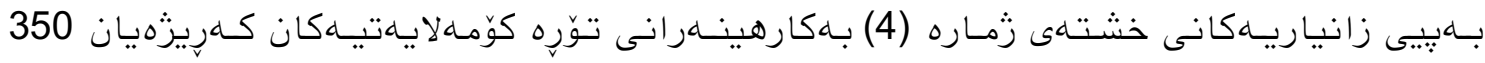

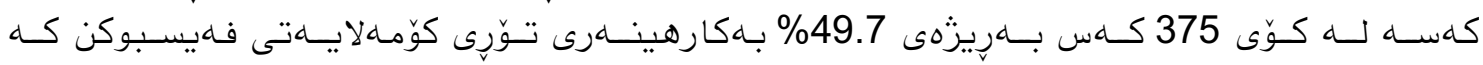

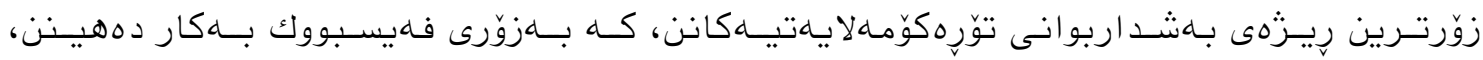

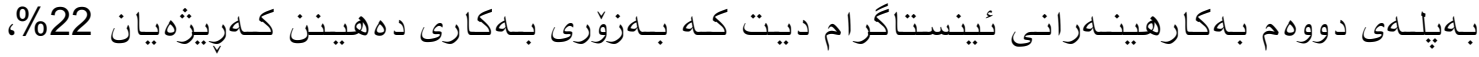

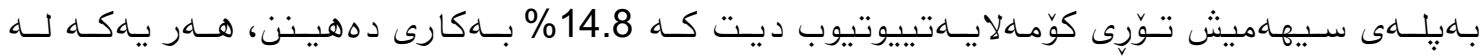

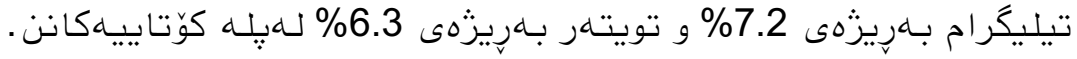

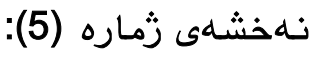

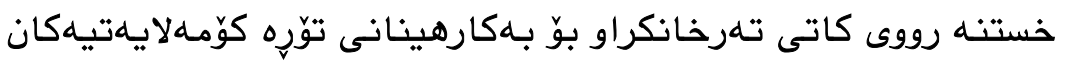

\begin{tabular}{|c|c|c|c|c|c|c|c|c|c|c|}
\hline \multirow[t]{2}{*}{ كوّ } & \multicolumn{2}{|c|}{6 - زياتر } & \multicolumn{2}{|r|}{$6-5$} & \multicolumn{2}{|r|}{$4-3$} & \multicolumn{2}{|r|}{$2-1$} & \multirow{2}{*}{ كَوْرِاو } & \multirow[b]{2}{*}{ j } \\
\hline & $\%$ & دوبـاره & $\%$ & دوباره & $\%$ & دوبـاره & $\%$ & دوباره & & \\
\hline 350 & $\% 11.5$ & 40 & $\% 47$ & 165 & $\% 27$ & 95 & $\% 14.5$ & 50 & فهيسبووك & 1 \\
\hline 350 & $\% 18.5$ & 65 & $\% 12.5$ & 45 & $\% 30$ & 105 & $\% 39$ & 135 & تويتهر & 2 \\
\hline 350 & $\% 21$ & 72 & $\% 22$ & 78 & $\% 28$ & 97 & $\% 29$ & 103 & يوتيوب & 3 \\
\hline 350 & $\% 14.5$ & 52 & $\% 47.5$ & 162 & $\% 21$ & 72 & $\% 18$ & 63 & يُينستاكرام & 4 \\
\hline 350 & $\% 5$ & 17 & $\% 13$ & 44 & $\% 19$ & 66 & $\% 64$ & 223 & تليكرام & 5 \\
\hline
\end{tabular}

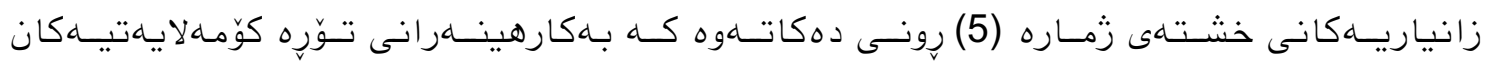

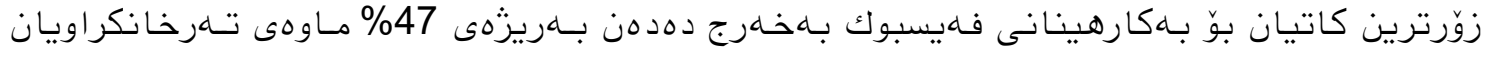




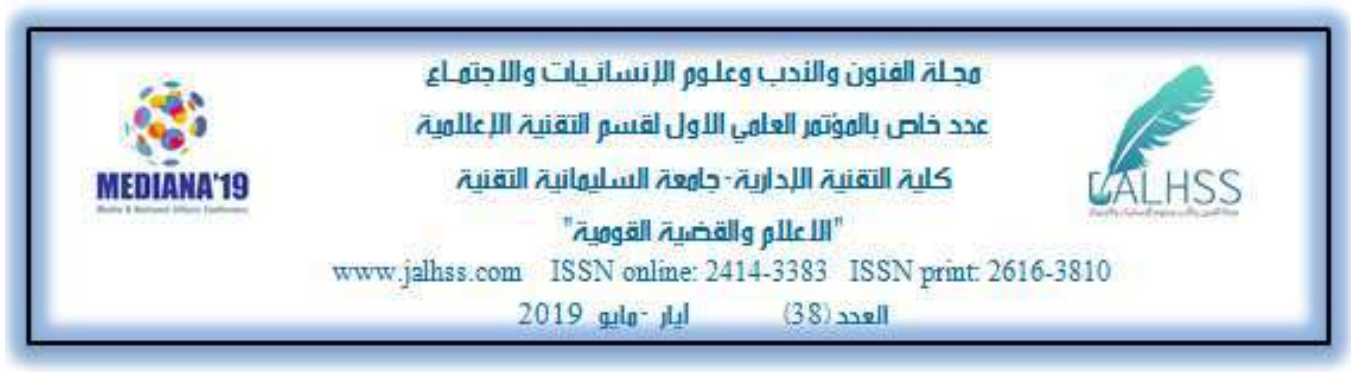

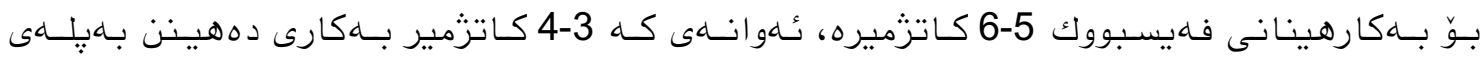

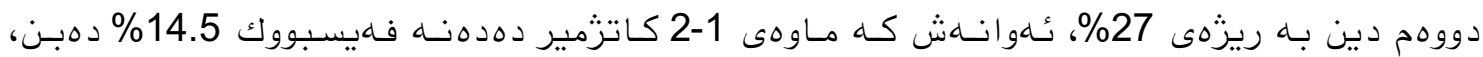

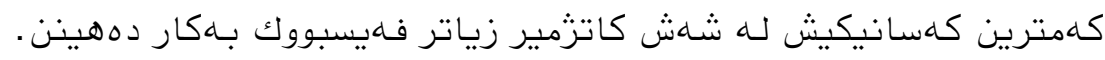

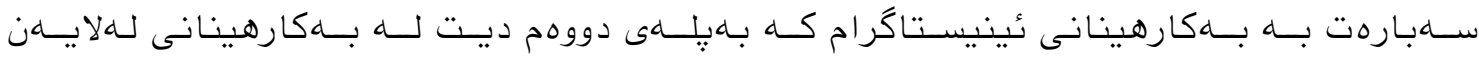

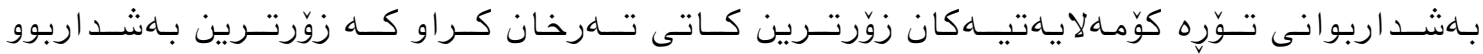

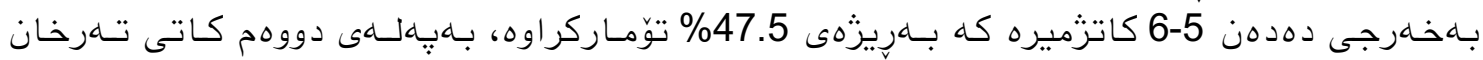

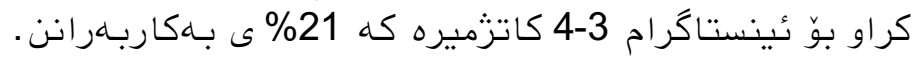

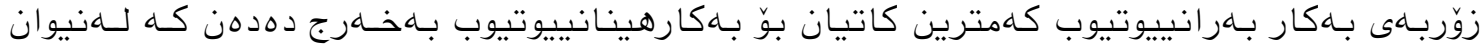

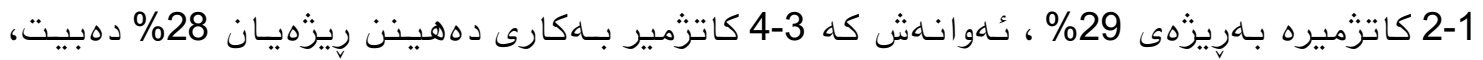

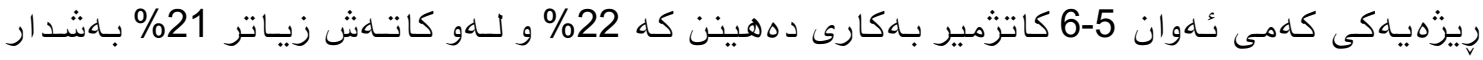
بوانن.

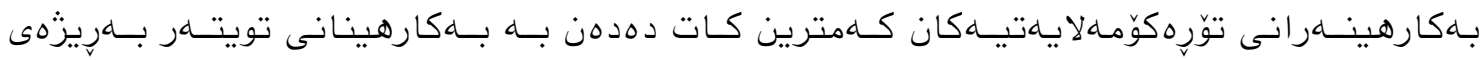

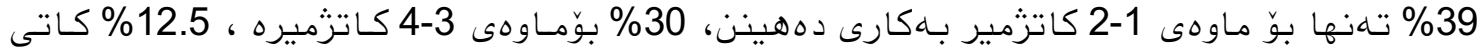

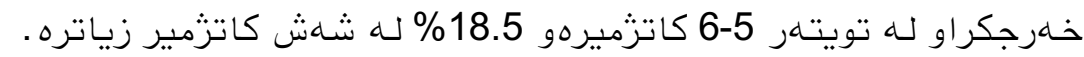

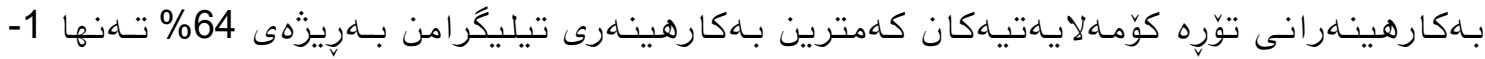

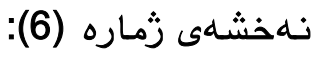

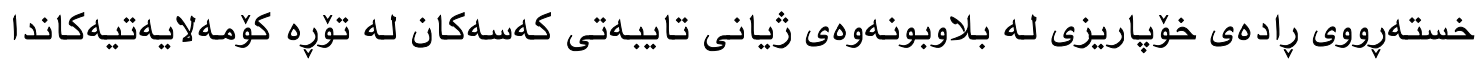

\begin{tabular}{|c|c|c|c|c|}
\hline يلـه & $\%$ & دوبـاره & كُوّراو & j \\
\hline يهكهم & $\% 56$ & 197 & زَوْر & 1 \\
\hline دووهم & $\% 23.5$ & 82 & تارادهيهك & 2 \\
\hline س..يهام & $\% 20.5$ & 71 & كهم & \\
\hline \multirow[t]{2}{*}{0} & 0 & 0 & هيج & \\
\hline & $\% 100$ & 350 & & كوّ \\
\hline
\end{tabular}

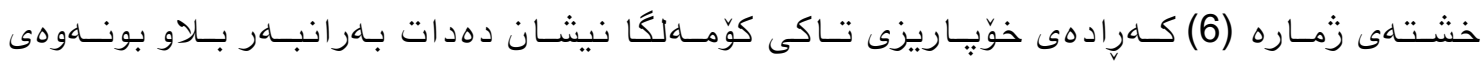

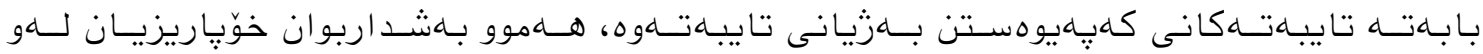

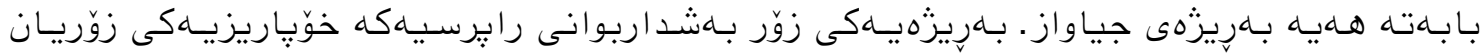

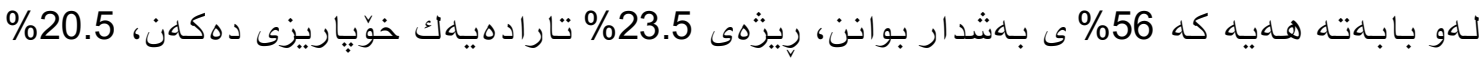

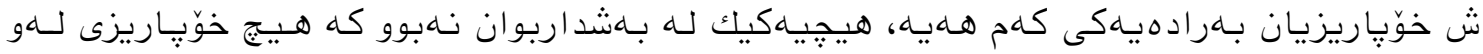




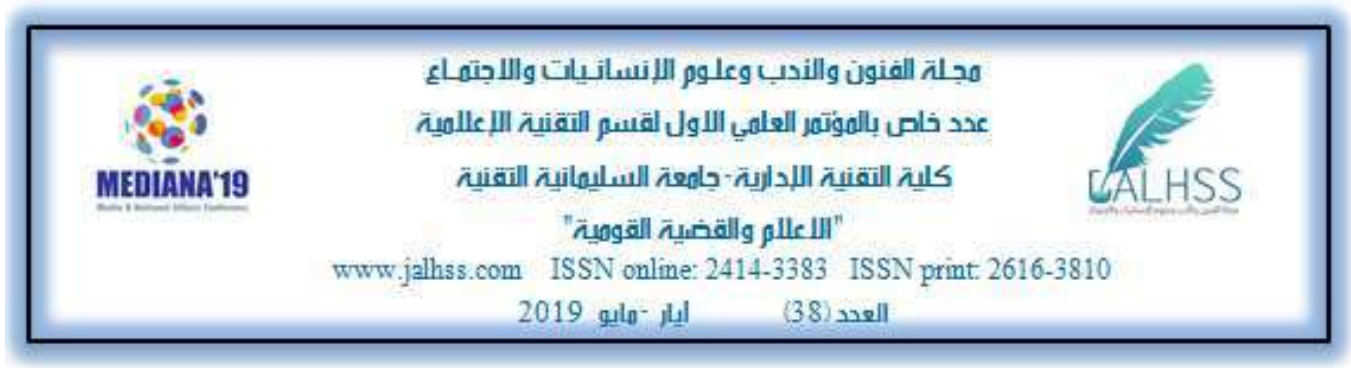

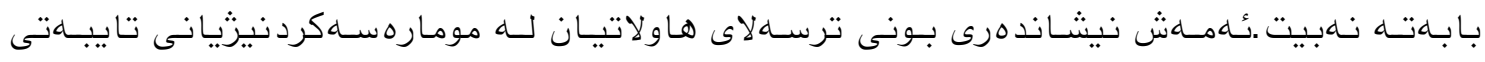

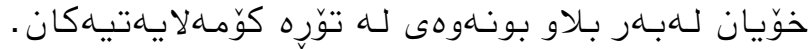

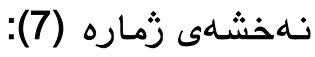

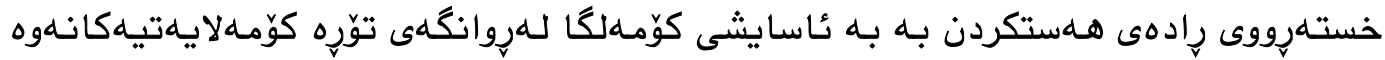

\begin{tabular}{|c|c|c|c|c|}
\hline يلبه & $\%$ & دوبـاره & كُوَراو & \\
\hline يهكهم & $\% 41$ & 145 & زَوَّر & 1 \\
\hline دووهم & $\% 28$ & 99 & تارادهيهك & 2 \\
\hline سيههمم & $\% 23$ & 81 & كهم & \\
\hline \multirow[t]{2}{*}{ جوارهم } & $\% 8$ & 25 & هيجج & \\
\hline & $\% 100$ & 350 & & وكو \\
\hline
\end{tabular}

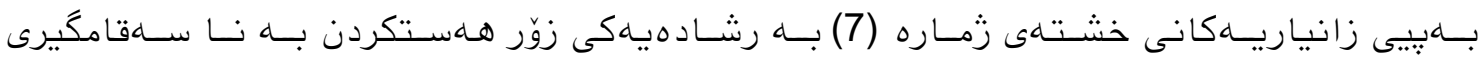

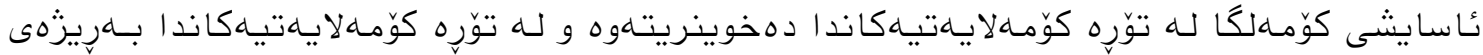

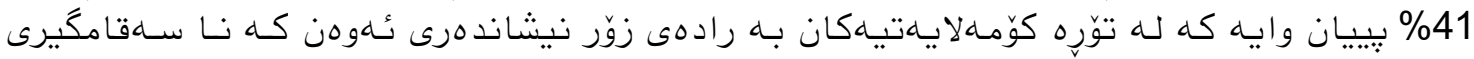

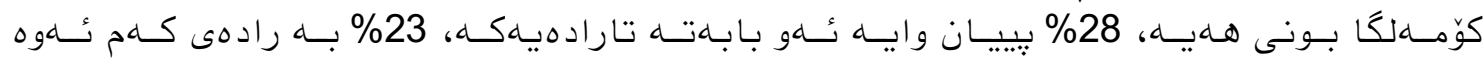

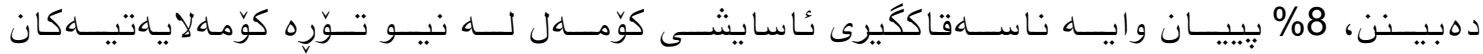

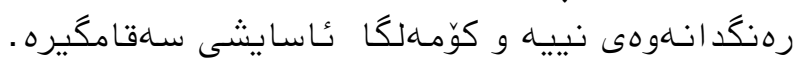

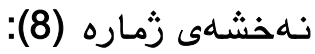

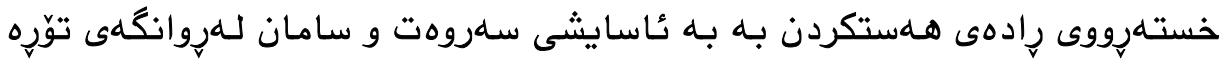
كوّمهلايهتيهكانهوه

\begin{tabular}{|c|c|c|c|c|}
\hline 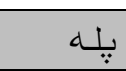 & $\%$ & دوباره & كَوْراو & $j$ \\
\hline دووهم & $\% 27$ & 95 & زَوْر & 1 \\
\hline سيههمم & $\% 25$ & 89 & تارادهيهك & 2 \\
\hline يهكهم & $\% 32$ & 111 & كهم & \\
\hline \multirow[t]{2}{*}{ جوارهم } & $\% 16$ & 55 & هيج & \\
\hline & $\% 100$ & 350 & & $\bar{r}$ \\
\hline
\end{tabular}




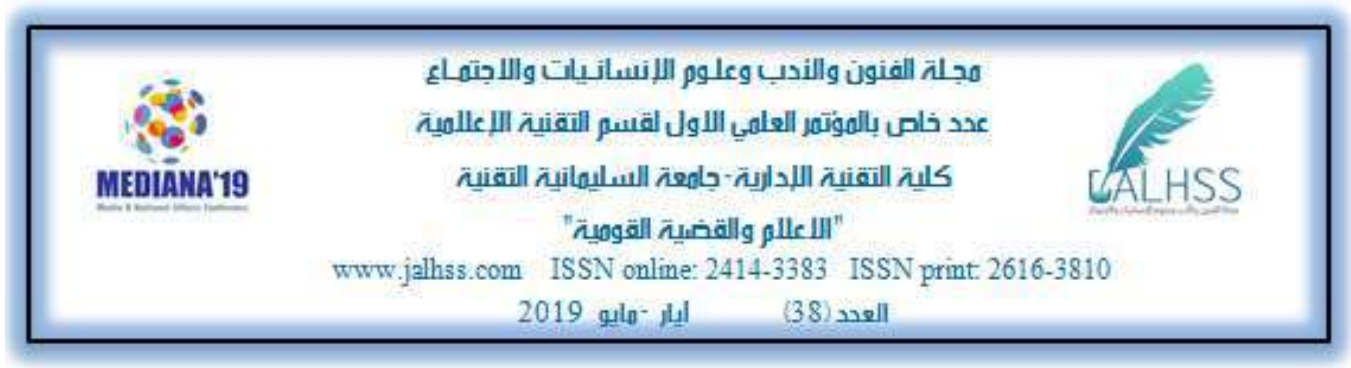

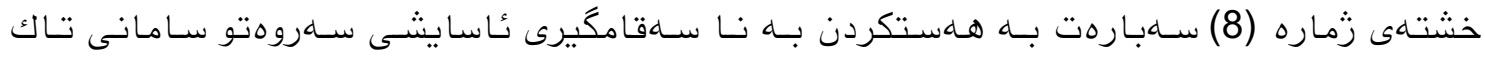

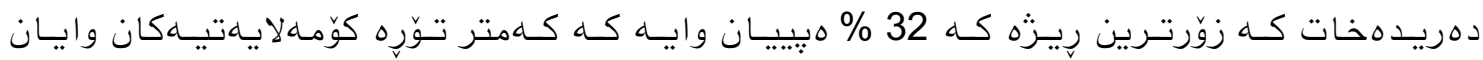

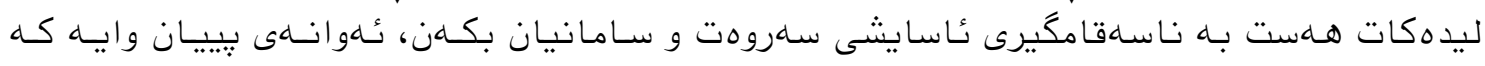

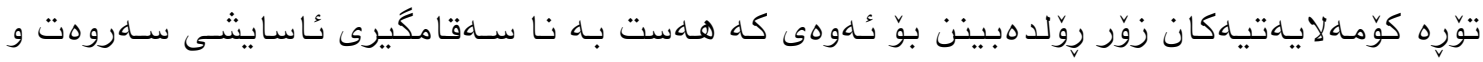

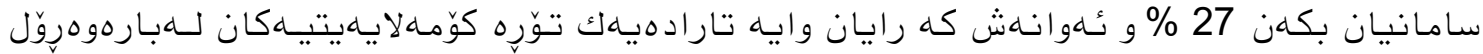

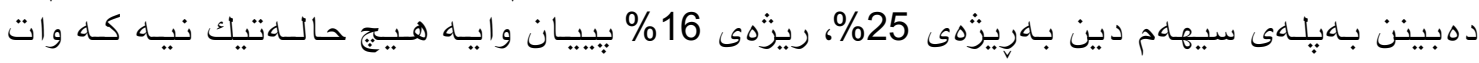

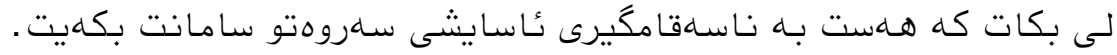

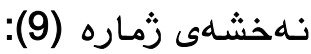

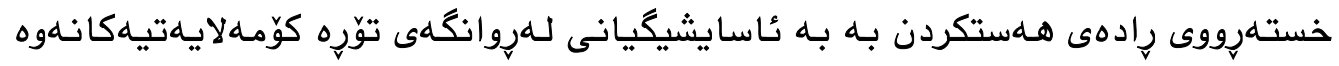

\begin{tabular}{|c|c|c|c|c|}
\hline بـله & $\%$ & دوباره & كَوْرِاو & j \\
\hline سيههام & $\% 23$ & 79 & زوَر & 1 \\
\hline جو ارهم & $\% 20$ & 71 & تارادهيهك & 2 \\
\hline يهكهم & $\% 33$ & 115 & كهم & \\
\hline \multirow[t]{2}{*}{ دووهم } & $\% 24$ & 85 & هيجج & \\
\hline & $\% 100$ & 350 & & كوّ \\
\hline
\end{tabular}

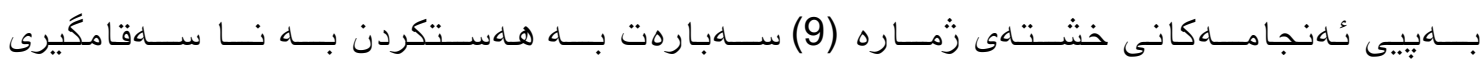

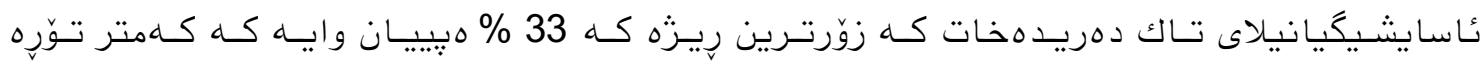

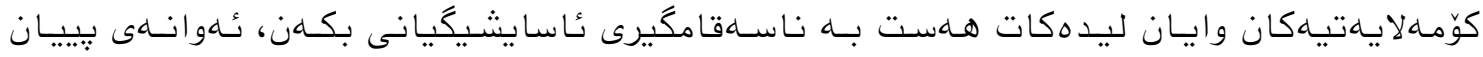

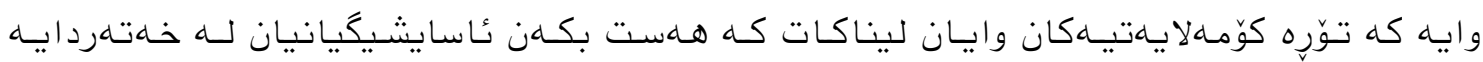

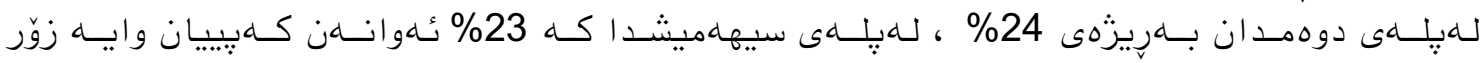

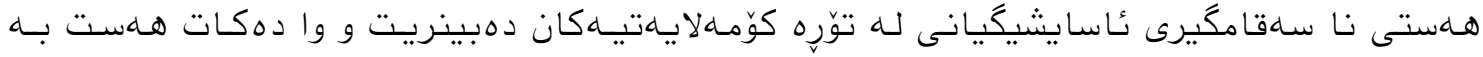

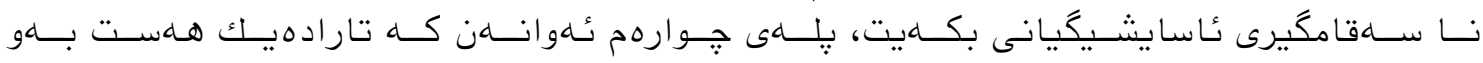

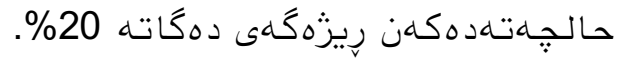




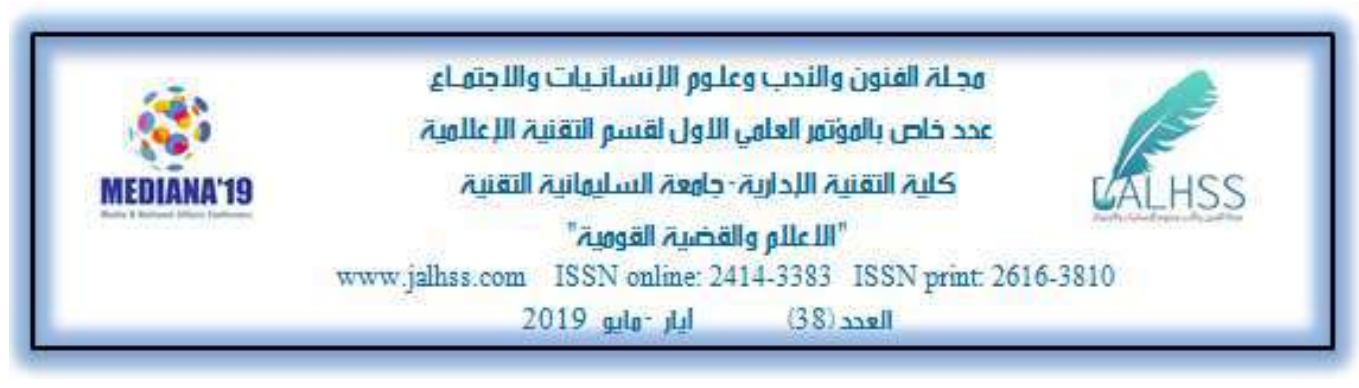

نهخشهى زماره (10)

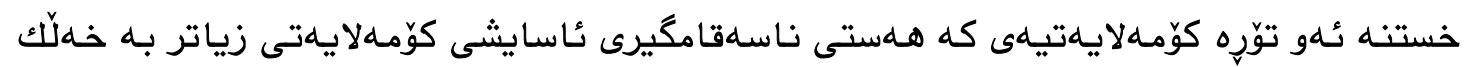
دهدات

\begin{tabular}{|c|c|c|c|c|}
\hline بـله & $\%$ & دوبـاره & كَوْرِاو & $j$ \\
\hline جوارهم & $\% 84$ & 290 & فهيسبووك & 1 \\
\hline يهككهم & $\% 1.5$ & 6 & تويتهر & 2 \\
\hline سيههام & $\% 11$ & 40 & يوتيوب & 3 \\
\hline بينجهـم & $\% 2$ & 8 & ئينستاكرام & 4 \\
\hline \multirow[t]{2}{*}{ دووهم } & $\% 1.5$ & 6 & تليكرام & 5 \\
\hline & $\% 100$ & 350 & & كوّ \\
\hline
\end{tabular}

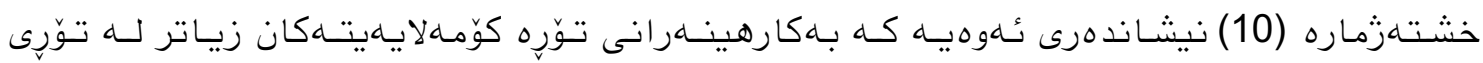

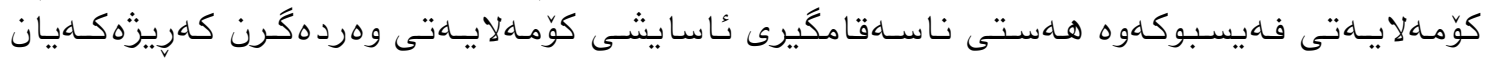

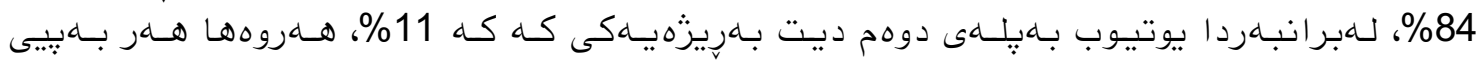

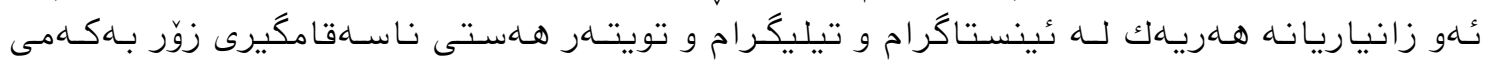

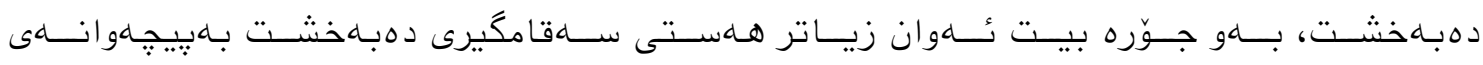
فهيسبووكهوها.

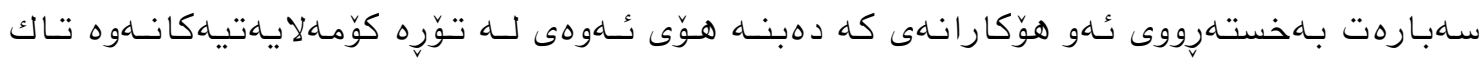

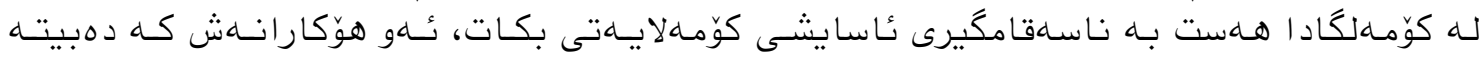

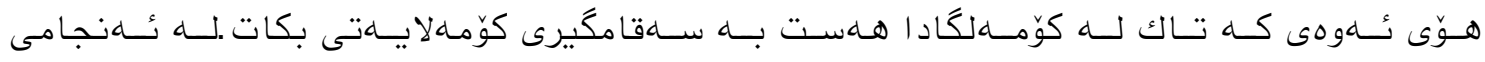

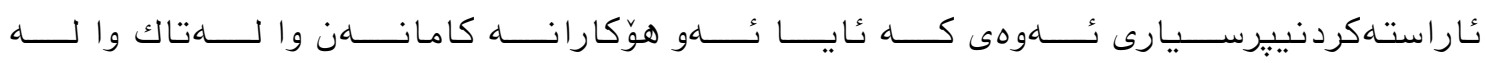

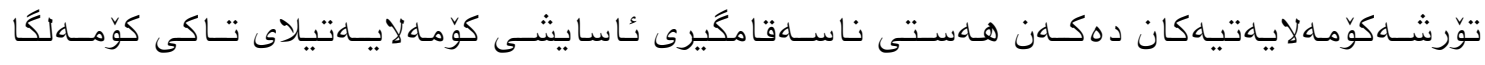

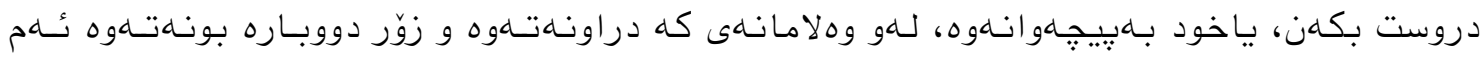

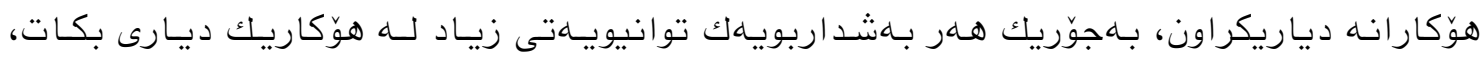

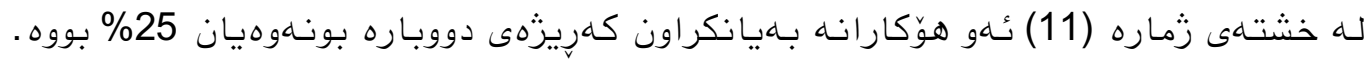




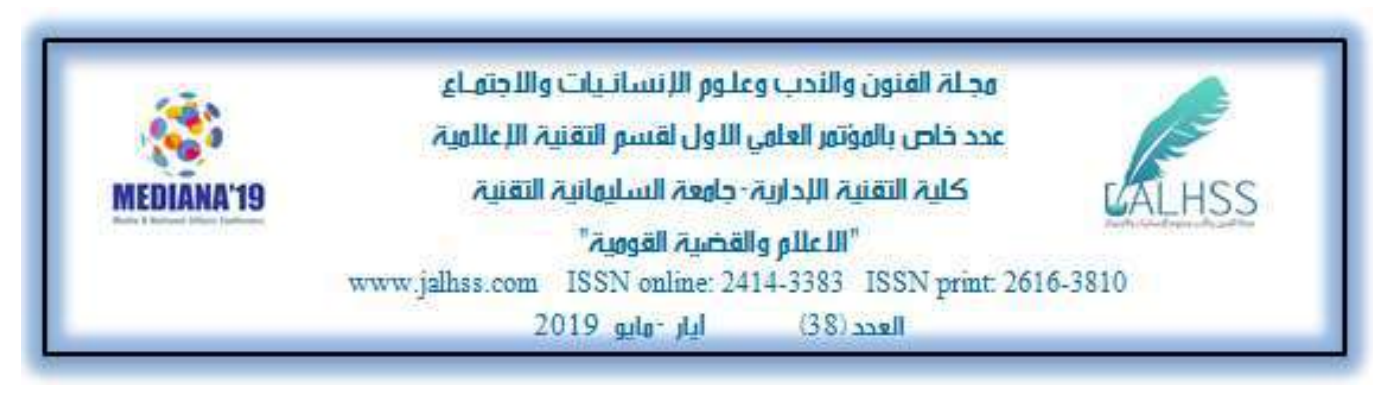

نه نشخهى زماره (11):

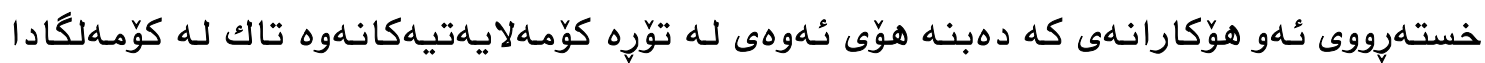

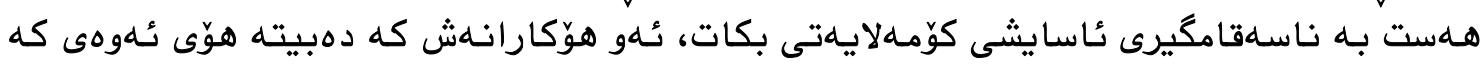

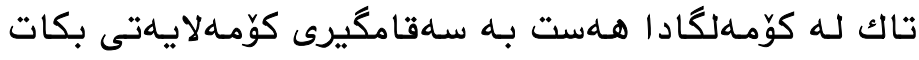

\begin{tabular}{|c|c|c|}
\hline 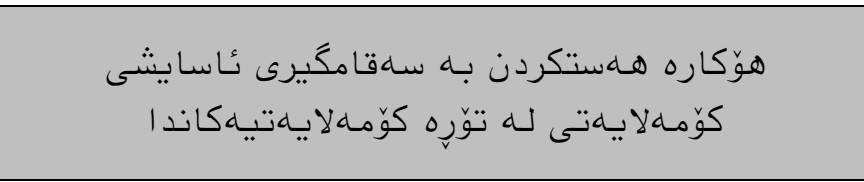 & 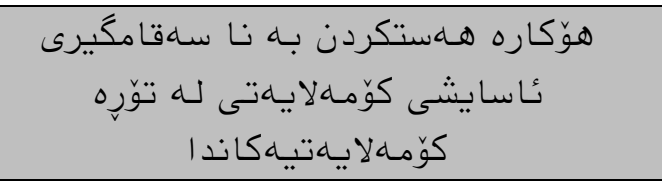 & j \\
\hline 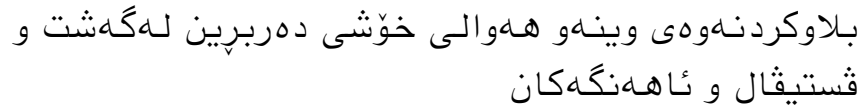 & 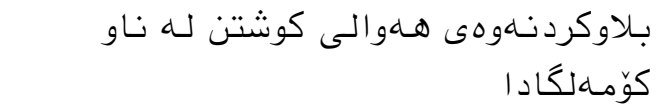 & 1 \\
\hline نيشاند انى بهرددواميجِا لاكيه هونهارى و زانستيهكان & بـلاوكردنـهوهى هـهوالى دزى و فراندن & 2 \\
\hline بينينيجِالاكيه وهرزشيهكان & 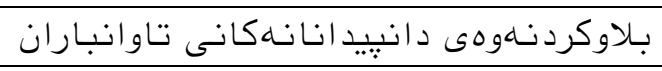 & 3 \\
\hline خاوانبارانه رووى جالاكى هيزه نُهنيهكان و دهـيركردنى & 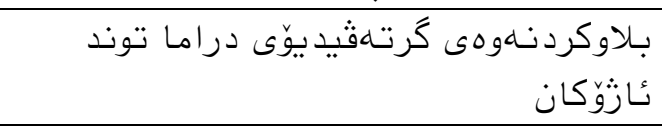 & 4 \\
\hline دهرخستن و نيشاند انى كهسانى دهست پاك & نوسينى كوّمينت و بِوّستى هلرهشهائاميز & 5 \\
\hline 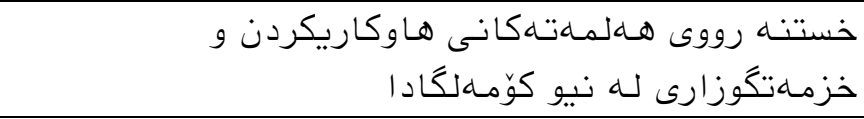 & وتهاولاتياند قسهى الناتهندروست و توند لـهلايفى & 6 \\
\hline 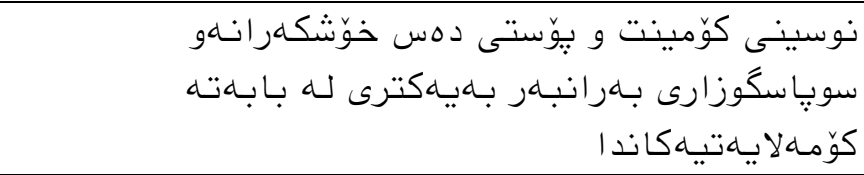 & 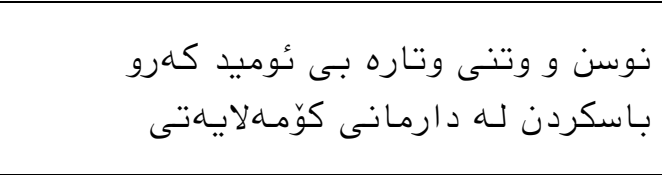 & 7 \\
\hline 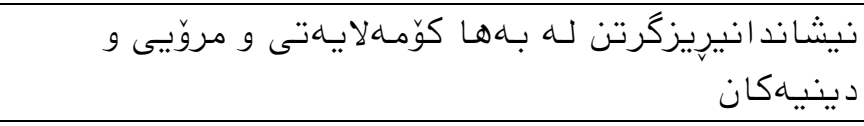 & 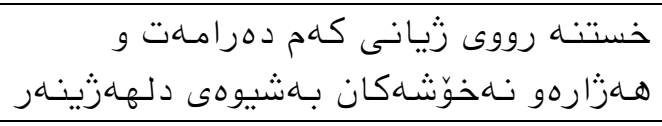 & 8 \\
\hline & 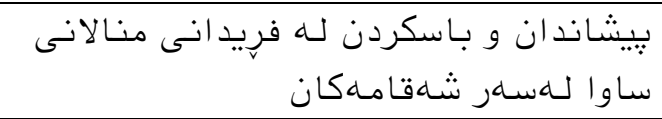 & 9 \\
\hline
\end{tabular}

\section{DOI: $10.33193 /$ JALHSS.38.5}




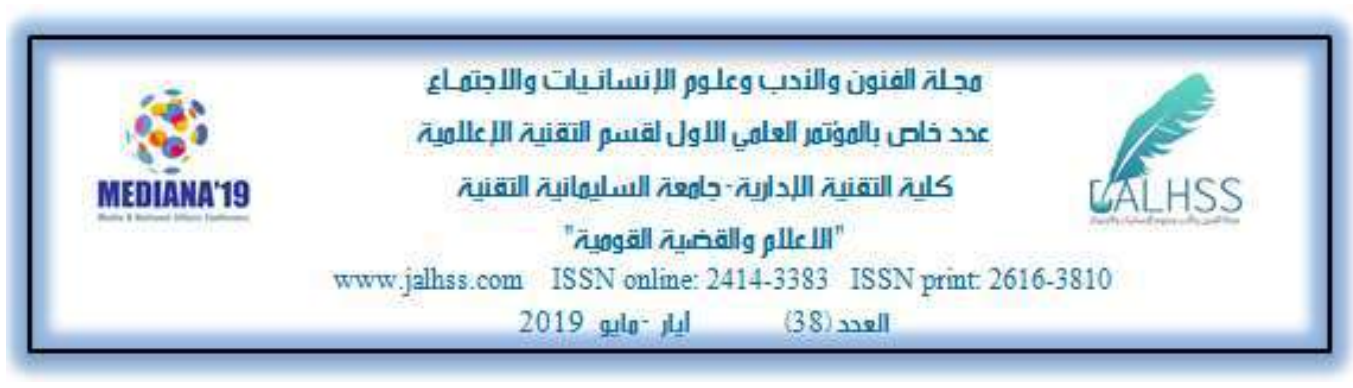

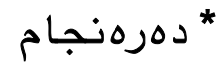

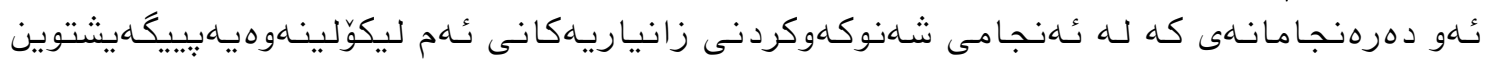
بريتين له

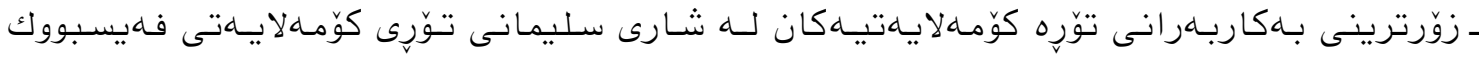

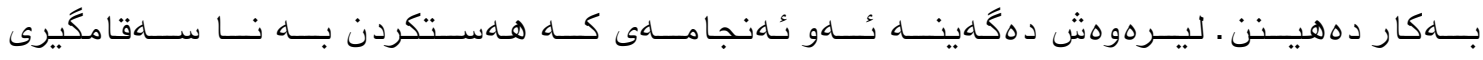

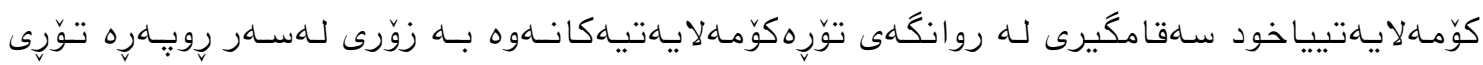

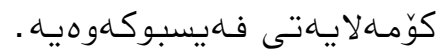

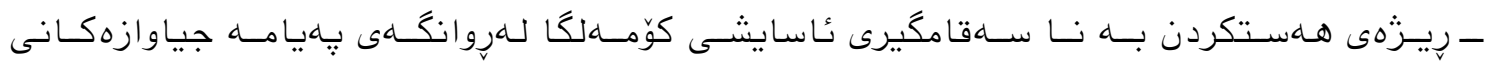

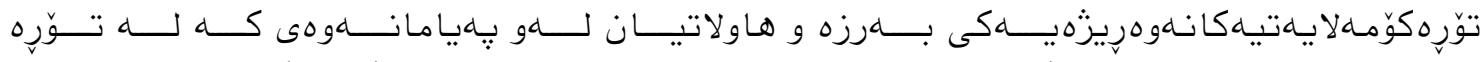

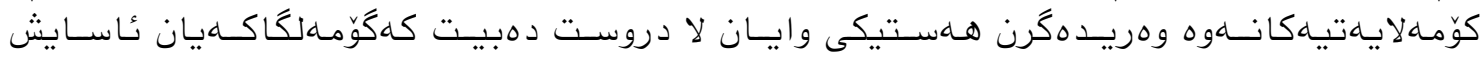

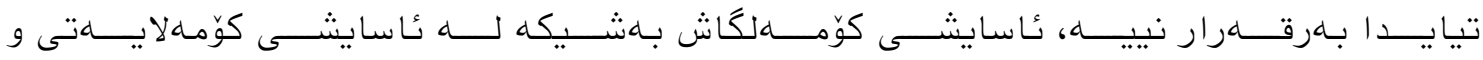

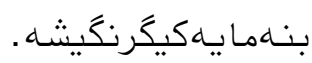

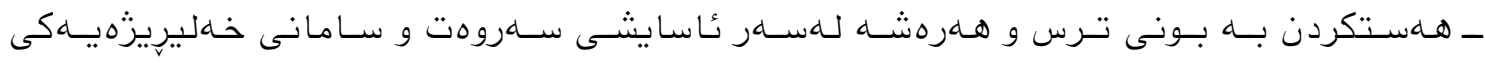

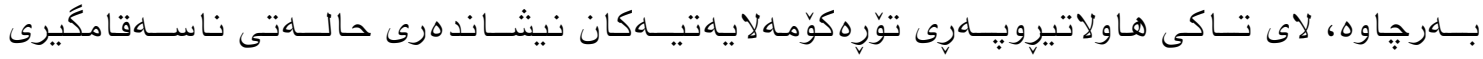

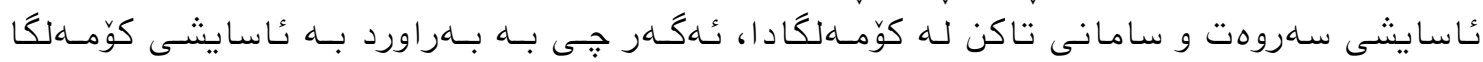

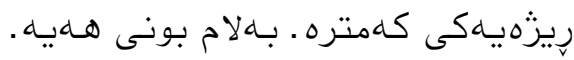

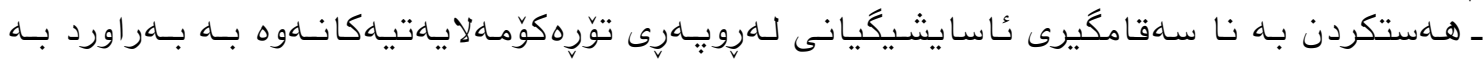

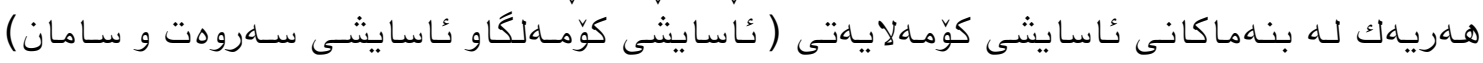

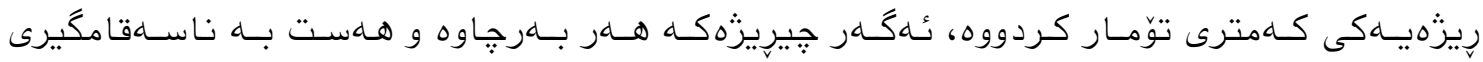

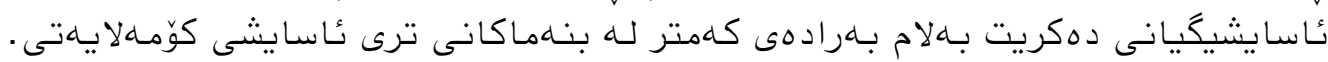

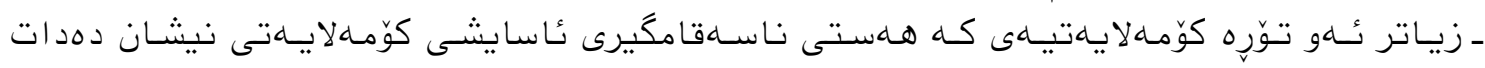

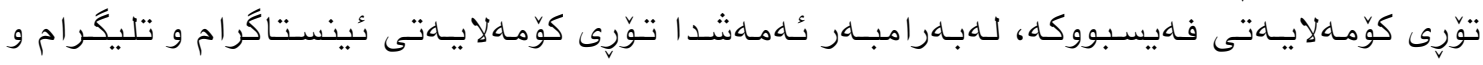

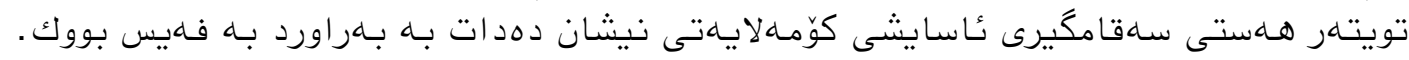

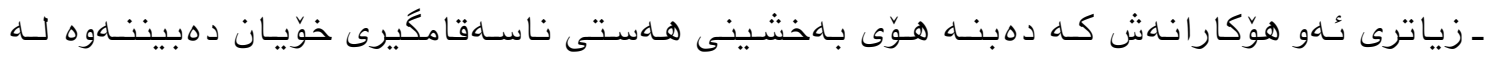

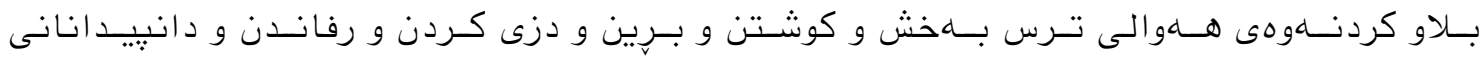

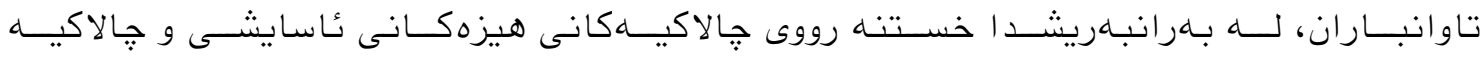

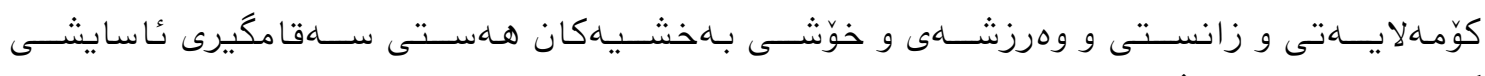

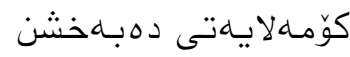




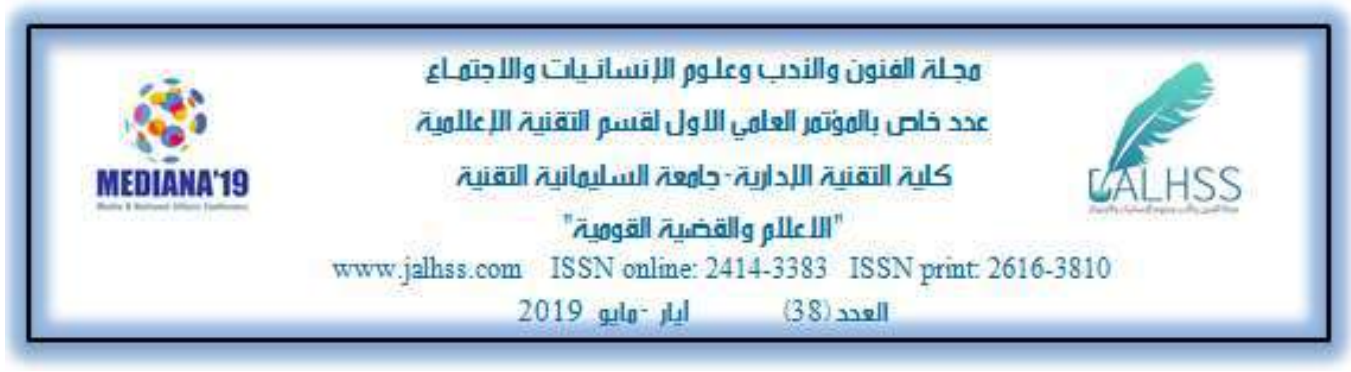

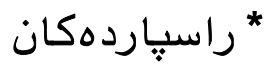

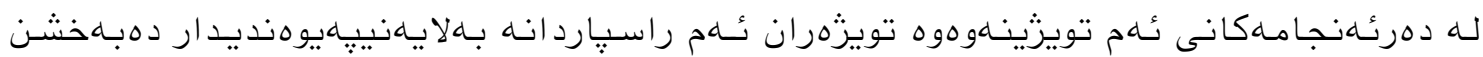

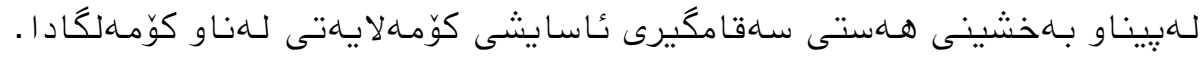

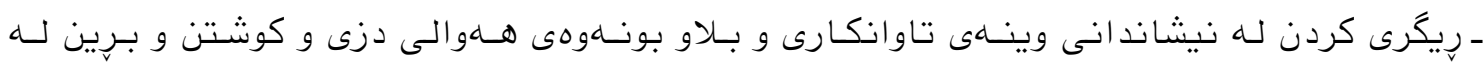

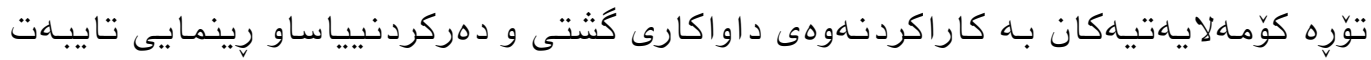

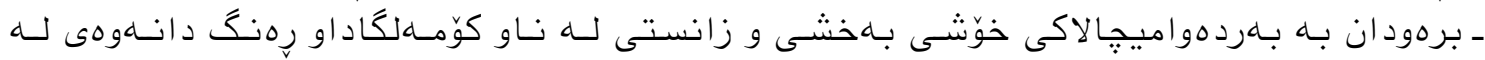

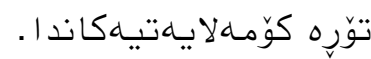

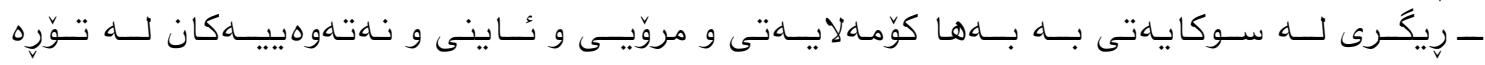

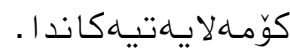

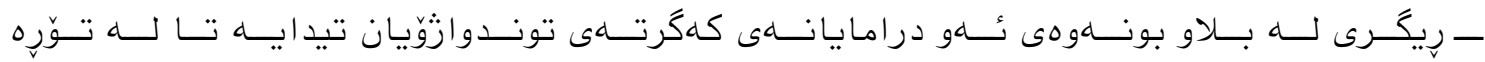

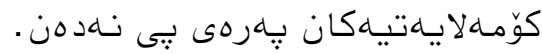

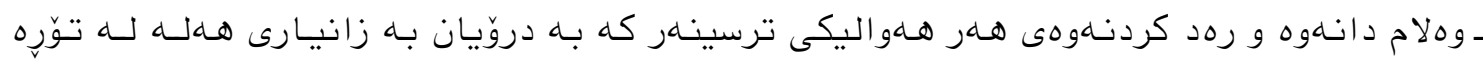

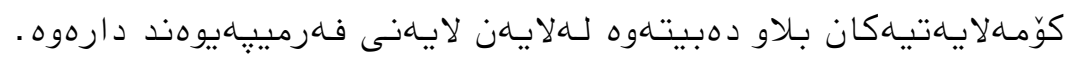

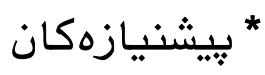

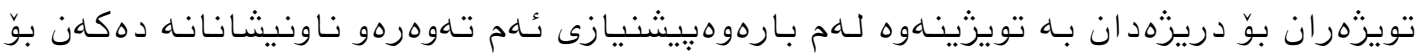

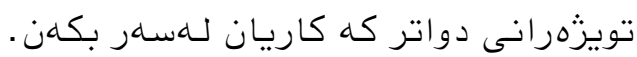

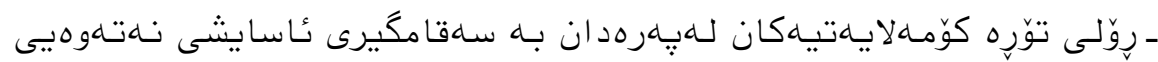

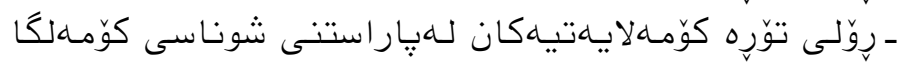

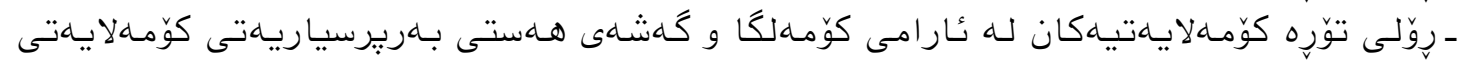

$$
\begin{aligned}
& \text { * سهرجّاوهان * } \\
& \text { سلرجاوهى علرهبى } \\
& \text { 1. إبراهيمأحمد الدوى، شبرهات شات التواصل الاجتماعى، } 2016 .
\end{aligned}
$$

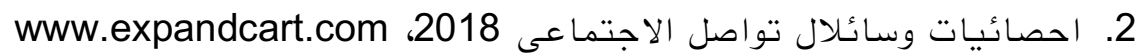

3. عباس صادق، الاعلام الجديد: المفاهيم والوسائل والتطبيقات، دار الإ الشروق للنشر

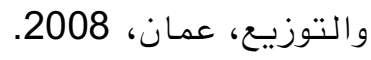

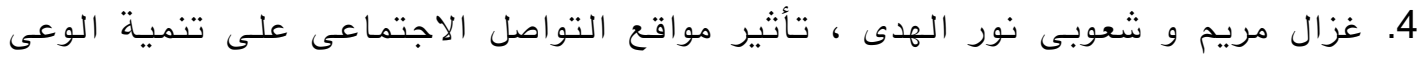

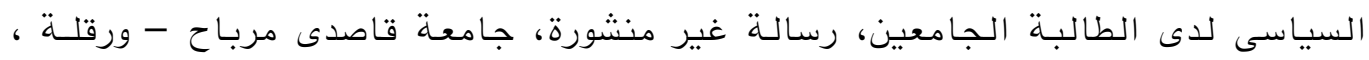

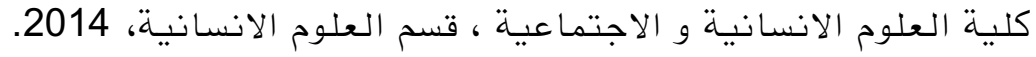




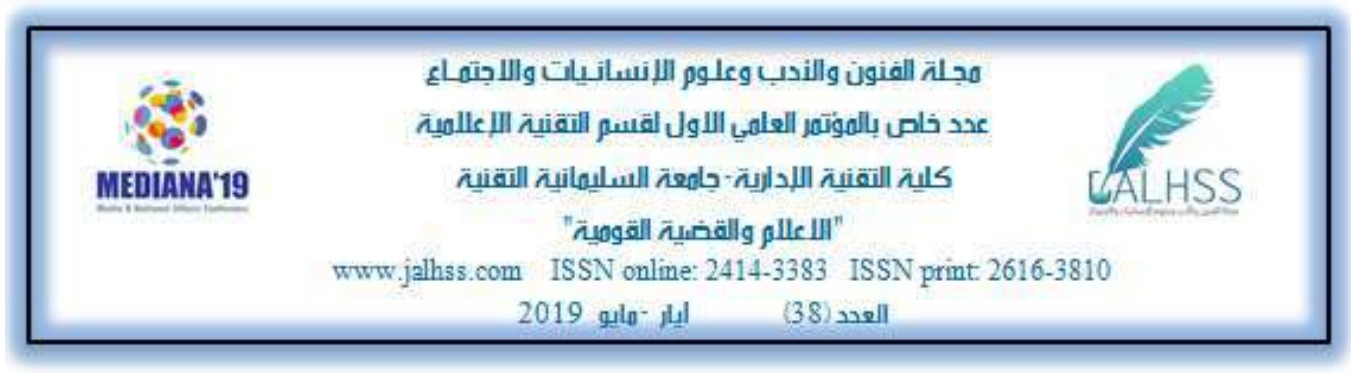

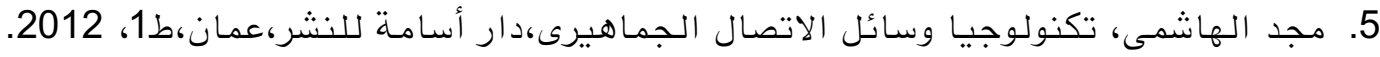

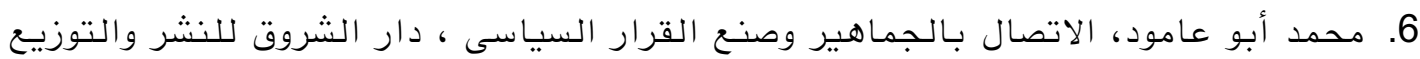
القاهرة، 2001.

$$
\text { 7. وليد رشاد زكىى، نظرية الشبكات الاجتماعية، } 2012 .
$$

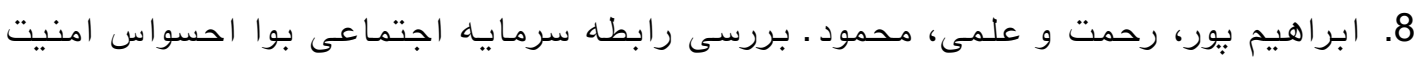

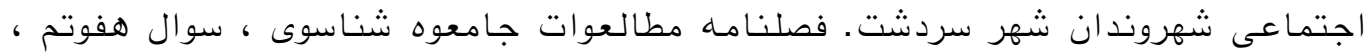
شماره بيست و شتشم،

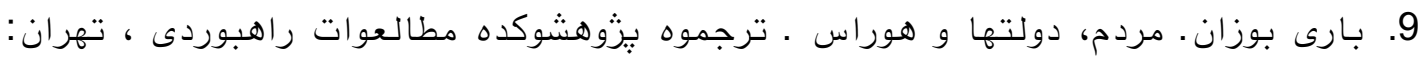

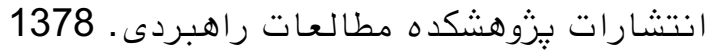

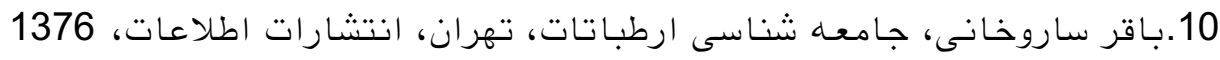

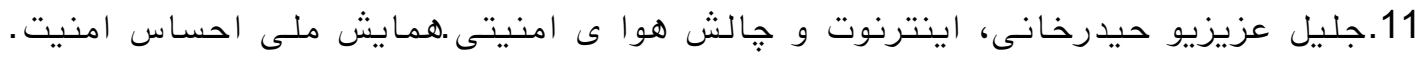
تابستان.

12.حسنروحانى، رسانههاى كروهى و امنيت ملى . راهبورد . شوماره 46 .زمسوتان و بهار.

13.حسين مصلحتى، منوجهر لرنى، جامعه شناسى امنيت، فصلنامه مطالعوات امنيت

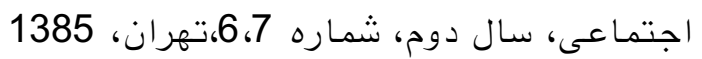

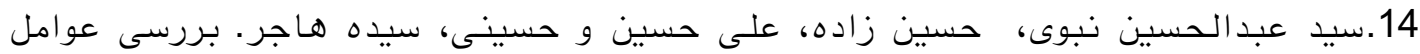

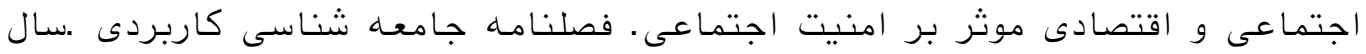
19،شماره 4، زمستان. 1389

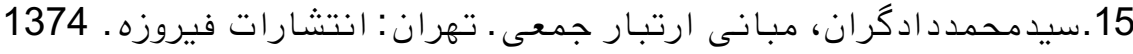

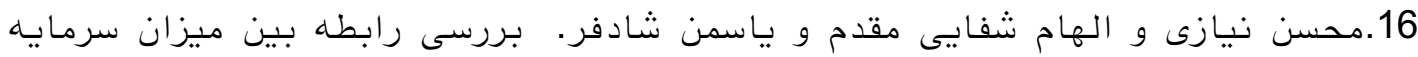

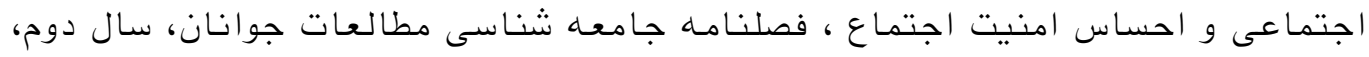
شماره سوم 9930

17.مسعود جلبى، .تحليل اجتماعى در فياى كنش ـ تهران، نشر نى. 1350

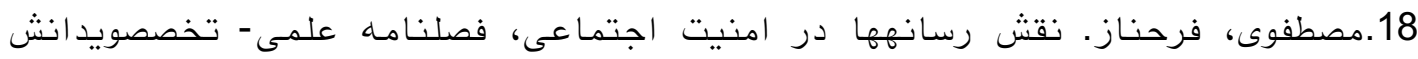
انتظامى پِليس ڤايتخت، سال هشتم، شماره 9 ، 1394

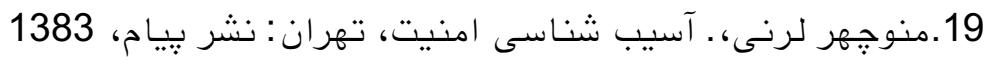

